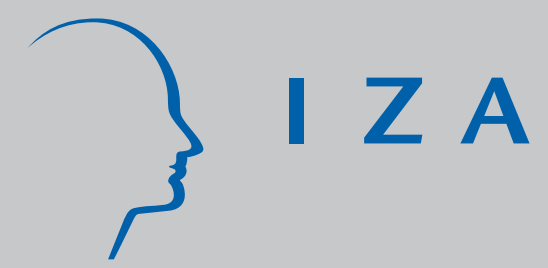

IZA DP No. 8240

Impacts of Unionization on Quality and Productivity: Regression Discontinuity Evidence from Nursing Homes

Aaron J. Sojourner Brigham R. Frandsen

Robert J. Town

David C. Grabowski

Michelle M. Chen

June 2014 


\title{
Impacts of Unionization on Quality and Productivity: Regression Discontinuity Evidence from Nursing Homes
}

\author{
Aaron J. Sojourner \\ University of Minnesota and IZA \\ Brigham R. Frandsen \\ Brigham Young University
}

\author{
David C. Grabowski \\ Harvard Medical School \\ Michelle M. Chen \\ Florida International University
}

\author{
Robert J. Town \\ University of Pennsylvania and NBER
}
Discussion Paper No. 8240
June 2014

IZA
P.O. Box 7240
53072 Bonn
Germany

Phone: +49-228-3894-0

Fax: +49-228-3894-180

E-mail: iza@iza.org

\begin{abstract}
Any opinions expressed here are those of the author(s) and not those of IZA. Research published in this series may include views on policy, but the institute itself takes no institutional policy positions. The IZA research network is committed to the IZA Guiding Principles of Research Integrity.

The Institute for the Study of Labor (IZA) in Bonn is a local and virtual international research center and a place of communication between science, politics and business. IZA is an independent nonprofit organization supported by Deutsche Post Foundation. The center is associated with the University of Bonn and offers a stimulating research environment through its international network, workshops and conferences, data service, project support, research visits and doctoral program. IZA engages in (i) original and internationally competitive research in all fields of labor economics, (ii) development of policy concepts, and (iii) dissemination of research results and concepts to the interested public.
\end{abstract}

IZA Discussion Papers often represent preliminary work and are circulated to encourage discussion. Citation of such a paper should account for its provisional character. A revised version may be available directly from the author. 


\section{ABSTRACT \\ Impacts of Unionization on Quality and Productivity: Regression Discontinuity Evidence from Nursing Homes ${ }^{*}$}

This paper studies the effects of nursing home unionization on numerous labor, establishment, and consumer outcomes using a regression discontinuity design. We find negative effects of unionization on staffing levels and no decline in care quality, suggesting positive labor productivity effects. Some evidence suggests that nursing homes in less competitive local product markets and those with lower union density at the time of election experienced stronger union employment effects. Unionization appears to raise wages for a given worker while also shifting the composition of the workforce away from higher-earning workers. By combining credible identification of union effects, a comprehensive set of outcomes over time with measures of market-level characteristics, this study generates some of the best evidence available on many controversial questions in the economics of unions. Furthermore, it generates evidence from the service sector, which has grown in importance and where evidence has been thin.

JEL Classification: J0, J5, D2

Keywords: trade union, nursing homes, labor productivity, regression discontinuity, collective bargaining, health care quality

Corresponding author:

Aaron J. Sojourner

University of Minnesota

321 19th Ave S 3-300

Minneapolis, MN 55455

USA

E-mail: asojourn@umn.edu

\footnotetext{
* Thanks to Tom Holmes for generous assistance with data acquisition and to Qihui Chen and Devon Phillips for excellent research assistance. This research uses data from the Census Bureau's Longitudinal Employer Household Dynamics Program, which was partially supported by the following National Science Foundation Grants: SES-9978093, SES-0339191 and ITR-0427889; National Institute on Aging Grant AG018854; and grants from the Alfred P. Sloan Foundation. Any opinions and conclusions expressed herein are those of the author and do not necessarily represent the views of the U.S. Census Bureau. All results have been reviewed to ensure that no confidential information is disclosed. Frandsen also gratefully acknowledges support from NSF Grant SES-0922355 and Sojourner from the U. Minnesota Grant-in-Aid of Research program.
} 
Understanding the impact of unionization is a long-standing, controversial, and difficult question in labor economics. Unions have potentially wide-reaching effects, from employment levels and the wage distribution to productivity, output quality, and establishment survival. These effects are critical both for current labor policy debates and for understanding broad labor market and production shifts in the U.S. economy. Economic theory yields ambiguous predictions on the direction of unions' impacts along many of these dimensions, highlighting the importance of the long empirical literature on unions effects (Mellow, 1981; Lewis, 1963; Freeman and Medoff, 1984; Hirsch and Addison, 1986; Hirsch, 2004).

A central challenge faced by much of the literature is credibly identifying causal effects. Unobserved differences between union and non-union workers or firms may bias traditional cross-sectional or fixed effects approaches. DiNardo and Lee (2004) overcame this challenge in introducing the regression discontinuity (RD) design to identify and estimate union effects using close union certification elections as a natural experiment. Their findings, which contrast with much of the previous literature, raise questions about the causal interpretation of prior, broader union-nonunion comparisons.

Another limitation of previous research is that most studies have focused on a relatively narrow aspect of unionization's impact due to data constraints. Studies of the union effect on wage levels and distribution (e.g., Card, 1996) are silent on establishment-level effects, and vice versa (DiNardo and Lee, 2004; Lee and Mas, 2009). Few, if any, studies have combined individual-level analysis with estimates of union effects on establishment-level outcomes, although the interpretation of union effects depend crucially on both. We make some contribution in this regard, though the cross-source matching demanded reduces sample size and precision of the individual-level analysis substantially.

In this paper we study the impact of unionization by applying RD analysis to a variety of outcomes focusing on a single industry: nursing homes. We link data from the National Labor Relations Board (NLRB) and Federal Mediation and Conciliation Service (FMCS) with detailed Centers for Medicare and Medicaid Services (CMS) data on nursing homes and Census Bureau data on individual earnings to analyze the effects of unions on employment, output, quality, earnings, and mobility. This study offers some of the best evidence available on union productivity effects and some of the only evidence from the service sector. To the best of our knowledge, this is the first study of the impact of unionization on output quality in which quality is reliably measured and unionization effects are plausibly identified.

There are a number of advantages to focusing empirical analysis on the nursing home industry. First, the activities of nursing home workers and technologies of production are very similar across organizations. Thus, we remove an important dimension of organizational heterogeneity that may confound study of an industry that encompasses more heterogeneity 
or of cross-industry analyses.

Second, we get a deep view into firms. Due to the large public role in the finance and regulation of nursing homes, detailed establishment-level outcome data exist across a broad range of labor, firm and consumer outcomes. Data are available for almost the entire industry nationally and in a panel across many years. We use this data to test theoretical predictions about how the union effect depends on the degree of economic rents, the elasticity of consumer demand, union density, and regulatory environment (Hirsch and Addison, 1986; Stewart, 1990; Booth, 1995). We are also able to cast empirical light on theoretical ambiguities, such as the union effect on employment levels, worker productivity, and firm growth and survival. The panel also permits falsification tests of the research design based on pre-election data.

Third, unions might be expected to have larger effects on firms and consumers in nursing homes than in many other industries, providing more potential to detect their impact. Here, labor is central to the production process. It makes up two-thirds of nursing home costs (Gertler and Waldman, 1992) and is the key input into the quality of patient care (Wunderlich, Sloan and Davis, 1996). Furthermore, the need to provide nursing home care that is proximate to residents' hometowns or families limits the possibility of outsourcing (Helpman and Krugman, 1987) and reduces the elasticity of consumer and labor demand. Our analysis thus focuses on the impact of unionization in a setting with potentially large effects.

Fourth, recognizing this potential, unions have made nursing homes a strategic organizing priority for more than 20 years (Sojourner, Chen, Grabowski and Town, 2011). Consequently, hundreds of union representation elections are available, permitting more powerful inference than a focus on most other industries would. It also means our analysis is relevant for an increasingly important segment of the economy in general, and the unionized sector in particular. Much of the previous literature, on the other hand, has focused largely on manufacturing, mining or construction, sectors that are declining both in the overall economy and the unionized sector. ${ }^{1}$

We find that unionization of a nursing home facility leads to significant declines in the mean number of nursing hours per resident day. These declines in staffing suggest that unionization leads to increases in the price of labor. Analysis of the Census bureau earnings data yields corroborating albeit noisy evidence. We also find evidence that unionization shifts the composition of the workforce at nursing homes toward lower-earning workers. The decline

\footnotetext{
${ }^{1} \mathrm{~A}$ larger fraction of the U.S. workforce and more union members now work in health care and social services than in manufacturing. According to the Bureau of Economic Analysis, the number of Americans employed in manufacturing fell by about 40 percent since 1970, from 18 million to 11 million, while the number in health care and social assistance grew by $533 \%$, from 3 million to 16 million. In terms of the incidence of unionization, the number of union members in manufacturing fell 76 percent between 1983 and 2010, from 5.8 to 1.4 million. Meanwhile, the number of union members in health care and social assistance rose by 133 percent, from 1.2 to 1.6 million over the same period (Hirsch and Macpherson, 2011).
} 
in staffing is not associated with changes in care quality, although these estimate effects are somewhat imprecise. That is, the evidence suggests that unionization increases labor productivity measured by both output per nursing hour and quality of care per nursing hour. To dig deeper, we analyze effects on a larger set of labor-sensitive care-quality measures, and find somewhat stronger evidence of no negative quality effect. There is also no evidence of a significant impact on other strategic margins such as establishment size, occupancy rates, resident case mix, or facility survival.

We also explore whether unions have heterogeneous impacts along three dimensions. First, we find larger effects in more concentrated markets (above median HHI), as predicted by theories of rent-sharing. Second, we find larger effects in less organized markets (below median union density), consistent with theories emphasizing threat effects and union substitution strategies by nonunion management in more organized markets. Finally, effects vary by the strength of state regulation of high-skill nurse staffing in complex ways consistent with basic economic theory. In less regulated states, unionization induces homes to reduce staffing levels across all skill levels. In states with tighter restrictions on the ability of homes to reduce higher-skill staffing levels, adjustments are concentrated on the margin of adjusting levels of less-skilled staff.

The remainder of the paper is organized as follows. The next section describes the institutional background of unionization and nursing homes and our data. Section 3 describes our empirical framework, based largely on Lee and Lemieux (2010). Section 4 focuses on evidence on the validity of our identification strategy. Section 5 presents our principal results. Section 6 concludes.

\section{Institutional Setting and Data}

\section{$1.1 \quad$ Institutional Setting}

The nursing home sector is large and growing. In 2009, nursing homes expenditures were approximately $\$ 187$ billion, and the sector employed more than 1.8 million people. Nursing homes provide long-term, custodial and post-inpatient recuperative and rehabilitation services for patients who suffer from significant disabilities that require 24-hour monitoring and care. The combination of an aging population and increasing life expectancy points to increasing demand for long-term nursing home care over the coming decades. The Bureau of Labor Statistics forecasts that employment in this sector will grow by 24 percent over the next decade. There are over 16,000 nursing homes operating in the US with 1.7 million

beds which care for 1.4 million patients. The dominant payer for nursing home patients is 
Medicaid with a little over 60 percent share of the patient population, with the remainder split between Medicare and private pay/privately insured patients. ${ }^{2}$ For-profit, not-for-profit and government owned firms all provide nursing home care with for-profit firms accounting for the majority (approximately two-thirds) of the facilities.

Unions have long focused on nursing homes as a ripe pool for their organizing efforts. In 1983, Services Employees International Union (SEIU) President John Sweeney initiated a campaign to organize hundreds of chain-affiliated nursing homes. Andy Stern, who succeeded Sweeney as SEIU President, vowed to increase organizing efforts directed towards nursing homes. This "Dignity, Rights and Respect" campaign aimed to organize 100 facilities a year. At approximately the same time, the United Food and Commercial Workers International (UFCW) began targeting southern nursing facilities. Dozens of other unions also attempted to organize long-term care facilities during these years. Despite this, unions have not kept pace with the industry's rapid growth and the unionized share of workers has declined, though at a slower rate than in many other sectors (Sojourner et al., 2011).

Nursing home care is labor intensive and the activities that nursing home employees perform (e.g. assist patients with bathing, toiletting, feeding, medication management and moving in and out of bed) are essentially the same across all facilities. Most direct patient care in nursing homes is provided by certified nursing assistants (NAs) who have limited professional training. Nursing homes also employ registered nurses (RNs) and licensed practical nurses (LPNs). RNs typically have two to four years of education at a college, university, or hospital. LPNs have nine months to one year of education, typically in a community college. RNs can provide direct patient care and often oversee LPN and NA staff. These different types of labor are imperfect substitutes for one another.

\subsection{Data Sources}

Our principal analysis dataset is the first national panel on nursing home characteristics that also includes information on labor relations at each home, including data on union elections, collective bargaining, and unionization status among each home's employees. Building off data assembled for Holmes (2006) we used records linked from the NLRB and the Federal Mediation and Conciliation Service (FMCS) from 1978 to 2002 to health systems data collected by the federal Centers for Medicare and Medicaid Services (CMS) from 1993 to 2008. CMS's Online Survey, Certification, and Reporting (OSCAR) system provides establishment-level data over time on each nursing home in the U.S. that cares for Medicaid- or Medicare-financed residents. It includes $96 \%$ of all U.S. nursing home establishments. The OSCAR data set

\footnotetext{
${ }^{2}$ Medicare covers post-acute care services for 100 days after a qualified inpatient stay at a hospital.
} 
contains information on facility characteristics and employment by type of worker. Importantly, OSCAR contains detailed data on quality of care. All of the measures constructed from this dataset (described below) have been used extensively in previous economic analyses of the nursing home industry (Cawley, Grabowski and Hirth, 2006; Grabowski, Gruber and Angelelli, 2008; Lu, forthcoming). We supplement our analysis with data on payroll and individual worker earnings and mobility available through the Census Bureau. Our sample includes all federally-financed, privately-owned nursing homes existing in years between 1991 and 2001. For this population, we have information on labor relations from the late 1970s to the early 2000s and outcome data for 1993 to 2008. We link information from several sources.

The NLRB elections records and FMCS bargaining notices provide information about each nursing home's unionization history. From the NLRB data, we observe when union certification elections occurred and the election results. The NLRB runs elections rules in response to petitions by groups of employees expressing a desire for union representation. The election is usually held at the nursing home. ${ }^{3}$ If a union receives a strict majority of the votes cast (i.e., 50 percent plus one) among the bargaining unit in question, then it is certified as the bargaining agent of the employees in the unit and the employer has a duty to bargain with the union. If the union loses, no such duty arises. This sharp difference in status due to a potentially small difference in voting outcomes provides the basis of the research design. In our nursing home population, on average unions received about 52.9 percent of the votes and won the election 55.8 percent of the time (Table 1). ${ }^{4}$ Figure 1 presents the fraction of elections in each vote share bin for the 627 focal elections. The distribution peaks in the first bin above the cut-off.

FMCS records contain information about the presence of a union contract. This is useful because many newly-certified bargaining units fail to reach initial contract agreements and the union may fade before establishing a toehold within the establishment. FMCS notices give reliable measures that a union is present, although absence of such notices is not a reliable indicator of union absence. In all private firms, the union and company have a duty to file notices of intent to bargain at least 30 days prior to contract expiry. These

\footnotetext{
${ }^{3}$ While we do not observe which employees are included in any particular election, most unions seek to represent all nursing-home employees, wall-to-wall. Others, such as the American Nurses Association, include only nurses. Allen (2004) writes that, in nursing homes, "Normally, employees in nursing, dietary, housekeeping, and laundry are the most likely to be unionized." The Supreme Court decided in 1994 that nurses who supervise lesser-skilled employees are not eligible to unionize and NLRB elections are often preceded by a hearing to decide exactly which nurses belong in the bargaining unit.

${ }^{4}$ This variable is not raw vote share. It is modified to account for the fact that the support of the raw vote share variable changes mechanically with the number of votes cast (DiNardo and Lee, 2004). For analysis, the shares are normalized so that a 50 percent vote share has the value 0 .
} 
are filed only if a union contract is in place. ${ }^{5}$ In the health care industry uniquely, firms are also required to file notices of intent to bargain for first contracts. These notices are filed subsequent to a union election victory but prior to signing an agreement. In some cases, the parties fail to reach agreement on an initial contract, the union dissipates, and the establishment may remain nonunion. Our measure of union presence in a nursing home is an indicator of having an FMCS notice filed more than a year post-election. We use the FMCS data in a falsification test and observe that certification really does lead to differential increases in unionization, similar to DiNardo and Lee (2004).

The OSCAR dataset provides establishment-level data from all Medicaid- and Medicarecertified nursing home facilities in the United States (96 percent of all facilities). The OSCAR data include information about nursing homes' compliance with federal regulatory requirements. Following an initial survey, states survey each facility about every 12 months on average and no less often than every 15 months. Following the survey, nursing homes submit facility, resident, and staffing information which are captured in the OSCAR data. The key employment variables constructed from the OSCAR data are hours per resident-day (HPRD) for NAs, RNs, and LPNs. In our data, nursing homes employ, on average, 2.13 NA, 0.77 LPN and 0.59 RN HPRD (Table 1). ${ }^{6}$ These three staff types are reported on the federal "Nursing Home Compare" report card website. Nursing home consumers and their support persons are encouraged to use this information, along with other quality measures provided on the web site, to help select a nursing home.

We also use the OSCAR data to construct measures of care quality. Under the direction of CMS, state surveyors use 175 consolidated measures encompassing structural, procedural, and outcome measures of quality to assign deficiencies during the regular inspection of nursing homes that are reported in the OSCAR data. Several alternative remedies could be imposed on facilities that receive a high number of deficiencies. These punishments include civil money penalties, denial of payment for new admissions, state monitoring, temporary management, immediate termination, and other approaches. Beyond their importance as a government oversight mechanism in monitoring nursing homes, deficiencies have long been used as an approximation for nursing home quality and are widely thought to depend on staffing levels (Konetzka, Yi, Norton and Kilpatrick, 2004). The federal government has made information on the number of deficiencies assigned to each certified facility nationwide available to consumers on its "Nursing Home Compare" web site. We construct two quality measures based on the deficiency data: the total number of deficiencies found and an indicator that a severe health deficiency was found. Table 1 shows that on average about

\footnotetext{
${ }^{5}$ However, it may not always be filed when contracts are in place; compliance is not perfect.

${ }^{6}$ We set staffing levels over 8 HPRD to missing, following (OMalley, Caudry and Grabowski, 2011).
} 
seven deficiencies were found in our nursing homes, and about 23 percent of homes had a severe deficiency. A third quality measure is market-based: the percentage of the home's residents who pay for their care with their own private funds rather than through Medicaid or Medicare. Although the Medicaid program is the dominant payer of nursing home services (accounting for about 50 percent of expenditures and roughly 70 percent of bed-days), private-pay residents are associated with higher profit margins relative to Medicaid residents and are therefore an important signal of facility resources (Mor, Zinn, Angelelli, Teno and Miller, 2004). To the extent that nursing homes compete to attract these higher margin clients by offering higher quality care, percentage private-pay can be taken as a market-based proxy for care quality. In our population, about 23 percent of patients were private-pay.

The OSCAR data also provides measures of other strategic operating margins that unionization might affect and which could be potential confounds in understanding union effects on productivity. These include each home's total number of beds (scale of production and firm growth), percentage of beds occupied (labor-capital ratio), and an acuity index of residents' health conditions, which measures the residents physical functioning level by incorporating both an activities of daily living index and the proportion of residents requiring special treatments. Our nursing homes house on average about 125.7 beds, have an occupancy rate of 84.8 percent, and have an acuity index of about 10.3 .

Since nursing home markets tend to be local, we also construct market-level variables which economic theory suggests may impact the magnitude of union effects. We construct Herfindahl-Hirschman Index (HHI) based on nursing homes' shares of total beds in a county. ${ }^{7}$ We also calculate the percentage of beds in a county that are in unionized homes by combining NLRB, FMCS, and OSCAR data, since theory also predicts that the impact of the unionization of a given establishment may depend upon penetration of unions into the relevant labor market (Booth, 1995; Hirsch and Addison, 1986), though the relationship is complex and the empirical implications ambiguous.

Finally, to get measures of earnings, we match via nursing home name and address to the U.S. Census Bureau's Longitudinal Business Database (LBD) and Longitudinal EmployerHousehold Dynamics data (LEHD). The LBD provides a panel of establishment-level measures of payroll and number of employees for all establishments. The LEHD provides a record of each employment relationship (an employee-employer match) and quarterly earnings for each employee and contains useful information to understand union effects but covers only 30 participating states (Frandsen, 2010). We analyze individual employee earnings for the subsample of nursing homes in these states. Although the Census data contains no measure of wages or hours, we construct an establishment-level measure of average wage by dividing

\footnotetext{
${ }^{7}$ Basing HHI on a home-specific, 25-mile radius market does not change results.
} 
the total wage bill from the LBD by the total employed FTE from the OSCAR data. We deflate all dollar amounts to year-2000 dollars.

\subsection{Sample Selection Criteria}

The NLRB, FMCS, and Census data cover only private (i.e., non-government) nursing homes. Thus, we exclude government-owned facilities (about 8 percent of total) from the establishment-level analysis. Our resulting sample consists of 22,357 unique licensed facilities; 14,556 were in operation in 1992, and 15,638 facilities in 2002. In our data, 2,088 facilities had at least one certification election between 1978 and 2001. Of these, 1,375 (66 percent) homes had at least one election where a union won. In the other 713 facilities with elections, the elections went against the union.

In the regression discontinuity analysis, we focus on NLRB certification elections that meet the following criteria:

1. At least 20 individuals voted. This minimizes the risk that the exact outcome could be perfectly controlled by the company, the union, or workers. This would undermine the quasi-randomization across the vote-share threshold (DiNardo and Lee, 2004; Lee and Lemieux, 2010). ${ }^{8}$

2. Occurred after at least one inspection report is observed in our OSCAR data for that home. The OSCAR data start in 1993. The last NLRB election in our data is from 2002. Therefore, all elections we consider occur in 1993-2002. The requirement of at least one pre-election OSCAR observation ensures our ability to use pre-election home characteristics for two important purposes (Lee and Lemieux, 2010). First, we can test for pre-election discontinuities in this rich set of baseline observable home characteristics. If such discontinuities were evident, this would cast doubt on the validity of the identifying assumptions. As these are the post-election outcomes of interest, it is very useful to see whether there were discontinuities prior to the election. Second, we can include baseline pre-election characteristics as explanatory variables in the analysis of union effects. These are not included to control for selection, but to reduce the variance unexplained influences and increase power, as in analysis of experimental treatment effects.

3. First such election observed in a home. Considering multiple elections for the same home raises a number of conceptual issues about whether a nursing home is treatment

\footnotetext{
${ }^{8}$ Bajari, Hong, Park and Town (2011) develop a method for when the value of the forcing variable is chosen.
} 
or control. Focusing on only the first post-OSCAR election in each home sidesteps these thorny issues. We terms this the home's focal election.

Another issue with multiple elections is the possibility that unions or management learn enough through recently-past elections to manipulate the outcome of the election in such a way as to introduce systematic differences across the threshold in unobservables and, thereby, to invalidate the identifying assumption. This concern diminishes as the time between elections extends. We exclude homes that experienced an NLRB election in the five years immediately prior to the focal election in our data.

4. In a home without evidence of unionized employees. We do this to clarify interpretation of the "treatment" as a contrast between homes with no unions certified as bargaining agent and any union so certified. We exclude elections in homes that had previously filed an FMCS notice of intent-to-bargain, which implies the presence of a union. Because the FMCS records extend back to the late 1970s and we consider elections in the 1993-2002 period, this gives us at least 15 years of history to examine. ${ }^{9}$

5. Nursing home that was not publicly owned. State agencies regulate publicly-owned homes' labor relations. Data from the federal NLRB and FMCS do not cover these homes so we do not have accurate measures of public homes' unionization status. This makes our estimates relevant to private-sector nursing homes, including both for-profit and not-for-profit, but silent on their effects in public-sector homes.

Applying criteria 1, 3, 4, and 5 yields a sample of 1,846 elections. Applying criteria 2, restricting the sample to the end of the period, cuts this to 627 elections. These are the focal elections used in the main analysis. A subsample of 429 could be matched to the Census data using establishment name, address and SIC code.

\section{Empirical Framework}

The principal challenge to identifying the causal effects of unionization is that outcomes at nursing homes that unionize are likely to be different from outcomes at nursing homes

\footnotetext{
${ }^{9}$ We may mistakenly include some long-time union homes in our sample. Homes that: (1) unionized prior to the start of our NLRB data (late 1970s), (2) whose union and management both consistently failed to comply with the FMCS requirement to file a notice of intent to bargain at each contract expiry, (3) had no NLRB election between the start of our NLRB data and the start of the OSCAR data, and (4) had an NLRB election after its first OSCAR observation. This does not undermine the validity of the design; it only moves the treatment a little closer to Dinardo and Lee's definition. Because they analyze all elections in any firm, the treatment is newly-certifying an agent to represent an additional bargaining unit in a home that may or may not already contain unionized workers.
} 
that do not unionize for reasons that have nothing to do with unionization. We overcome this selection bias problem using a regression discontinuity design based on close union certification elections, an approach first used in the union context by DiNardo and Lee (2004). The idea is that nursing homes where a union barely lost a certification election should be similar to nursing homes where a union barely won, and thus post-election differences that are observed between them can be attributed to the effects of union certification. We largely adopt DiNardo and Lee's set up, although some differences in data structure require modest adjustments.

Our basic empirical model expresses the conditional mean of outcome $Y_{i t}$ of nursing home $i$ at post-election date $t$ (defined as the time elapsed since a certification election) as a function of union certification status, $D_{i}$, the normalized vote share for the union, $X_{i}$ (centered at zero and adjusted as in DiNardo and Lee), and other nursing home characteristics, $W_{i t}$, which can include lagged outcome values:

$$
Y_{i t}=D_{i} \tau+f\left(X_{i}\right)+W_{i t} \delta_{1}+U_{i t}
$$

where union certification depends deterministically on the vote share, $D_{i}=1\left[X_{i}>0\right]$, and $f(\cdot)$ is continuous at zero.

The causal effect of unionization for unions near the threshold of certification is identified by the coefficient $\tau$ under the following continuity assumption on unobservable influences $U_{i t}$ :

$$
\lim _{x \uparrow 0} E\left(U_{i t} \mid W_{i t}, X_{i}=x\right)=\lim _{x \downarrow 0} E\left(U_{i t} \mid W_{i t}, X_{i}=x\right)
$$

This assumption means that no (unobserved) factor influences the outcome in a discontinuous manner across the election victory threshold other than union certification status, so any observed average differences across the threshold can be attributed to the causal effects of unionization.

This assumption would be satisfied if close elections were literally as random as coin flips. Of course, elections are not coin flips, but as long as there is some stochastic element in the final vote tally, the condition should be satisfied. Restricting to elections with more than 20 voters, as described above, should make this more plausible.

We estimate the union effect $\tau$ using local linear regression (Hahn, Todd and Van der Klaauw, 2001) and a triangular kernel with bandwidth chosen optimally according to Imbens and Kalyanaramang (2009) (IK-optimal). This essentially restricts analysis to nursing homes that experienced close elections. We show the results are not qualitatively sensitive to choice of functional form $f$, bandwidth, or control set $(W)$ through a series of robustness tests with results detailed in the Appendix. In order to allow for the possibility of errors cor- 
related within home across observations, we estimate standard errors using a home-clustered bootstrap $(\mathrm{M}=200)$.

Both to assess robustness and improve precision, we estimate effects using three basic specifications, which differ by the set of included covariates $(W)$. Specification 1 includes no covariates beyond vote share. Specification 2 includes nursing home $i$ 's pre-election mean of the dependent variable as a regressor. Specification 3 includes the home's full vector of pre-election means for all OSCAR characteristics. If the identifying assumption is valid, all three specifications should give similar estimates and the specifications with additional covariates should be more precise, as in a randomized control experiment.

\section{Evidence of RD Validity}

\subsection{Test for pre-election discontinuities}

The RD design is premised on the assumption that no systematic differences exist in the populations of homes across the threshold before the election. A large advantage of RD designs over control function approaches is that it delivers these testable, falsifiable implications (DiNardo and Lee, 2011). We test this with respect to, first, the density of vote share and, second, the mean of observable pre-election characteristics. First, a McCrary test returns a $p$-value of 0.33 , consistent with a valid design. However, the test is not strictly valid for discrete forcing variables. We also implement the Frandsen (2013) test, developed for this setting, and obtain a $p$-value of 0.69 , also consistent with a valid design.

Second, we test for a discontinuity with respect to characteristics observable up to the date of the election. We focus on homes with elections occurring after at least one OSCAR observation is available precisely in order to enable this kind of falsification test. In formal terms, we want to test the joint hypothesis that $\tau_{k}=0$ for all $k$ for $t \leq 0$. We use local linear regression as in the main results below, but estimated as a system (Lee and Lemieux, 2010), to facilitate joint hypothesis testing while allowing for possible correlation in errors within home across characteristics (dimensions of $Y$ ). Each observed $Y_{i t k}$ for $t \leq 0$ is included as an outcome, the 4 parameters for a piecewise linear function of vote share are interacted with a vector of $k$-indicators.

$$
\begin{aligned}
Y_{i t 1} & =\beta_{01}+\beta_{11} X_{i}+\tau_{1} D_{i}+\beta_{21} D_{i} X_{i}+\epsilon_{i t 1} \\
Y_{i t 2} & =\beta_{02}+\beta_{12} X_{i}+\tau_{2} D_{i}+\beta_{22} D_{i} X_{i}+\epsilon_{i t 2} \\
\cdots & \\
Y_{i t K} & =\beta_{0 K}+\beta_{1 K} X_{i}+\tau_{K} D_{i}+\beta_{2 K} D_{i} X_{i}+\epsilon_{i t K}
\end{aligned}
$$


We use only observations from homes that have elections with vote shares close to the threshold, where "close" is defined as within a given bandwidth $(h)$ of the threshold. We vary $h$ to assess sensitivity.

Tests for discontinuities in a wide array of pre-election nursing home and election characteristics reveal no evidence of selection. Discontinuity estimates for each characteristic $\left(\hat{\tau}_{k}\right)$ from this analysis are presented in Table 2. In addition to the nursing home characteristics from OSCAR that are the focus of our analysis, we also include two characteristics of the focal NLRB election in order to provide an even stronger test: the logs of bargaining unit size and number of valid votes cast. Columns correspond to different values of $h$. The final row presents the $p$-value from the joint hypothesis test. At each bandwidth, the joint hypothesis is not rejected. There is not evidence of systematic differences across the threshold in nursing home characteristics prior to the election. ${ }^{10}$

\subsection{Certification and unionization}

The variable actually determined by a union election is union certification, and this is not equivalent to unionization. ${ }^{11}$ To show that our RD design based on union certification is informative about the effects of unionization, we present evidence that certification raises the probability of establishing union collective-bargaining agreements. We consider whether each home had any FMCS notice of intent to bargain filed anytime after the first post-certification year. ${ }^{12}$ About half of unionized firms do not file FMCS notices (DiNardo and Lee, 2004). If half of certifications lead to first contracts and half of contracts lead to FMCS filings, then we would expect a 25 percentage point effect on filings after the first post-certification year.

In fact, that is what the data show. Figure 2 presents the share of homes with postcertification FMCS filings by vote-share bin as well as expected share estimated using local linear regression and the IK-optimal bandwidth. There is a large discontinuity in the prob-

\footnotetext{
${ }^{10}$ Allowing errors to be correlated within home and measure $i k$ across time $t$ rather than within $i$ across $k t$ gives similar results. Using piecewise quadratic functions of vote share also produces similar results (Table A.1).

${ }^{11}$ Slippage can occur in both directions. On one hand, achieving NLRB certification is no guarantee that a union will take root. Certification creates a duty to bargain collectively but not to reach agreement. Consistent with Bronfenbrenner (2003), Ferguson (2008) finds first contracts are reached in 56 percent of establishments in the first year after union certification. In the other cases, unionization may wither and the home remain nonunion. On the other hand, unions may organize outside the NLRB election process. These homes are not directly relevant to the $\mathrm{RD}$ analysis carried out here but are indirectly relevant in two ways. First, if an FMCS notice is subsequently filed in a home that organizes outside the NLRB process, the home is counted as union for the purpose of measuring the market's union density for nearby homes that later experience elections. Secondly, if unions form outside the NLRB process in homes where unions previously lost NLRB elections, this would also diminish the chance of finding an effect.

${ }^{12}$ In health care uniquely, notice is required for first-contract bargaining rather than only at re-negotiation. Therefore, notices in the first post-certification year may not indicate the existence a signed agreements.
} 
ability of FMCS filing at the vote-share threshold. Where the union just loses the election, only 16 percent of homes experience subsequent filings, presumably due to subsequent unionization efforts. Certification is estimated to cause a 23 percentage point increase in filing likelihood, excluding the first post-certification year.

If certification principally impacts nursing home operations through helping unionization persist, the direction of the certification effects in these homes should be the same as the direction of union effects. Our primary results come from signing effects so we use the terms certification and unionization effects interchangeably. However, the magnitude of effects of unions taking root in firms may be larger than these certification effects. ${ }^{13}$

In sum, the RD approach appears valid as there is no systematic discontinuity in nursing home characteristics prior to the certification election. Further, union certification appears to lead to union contracts in about half of cases.

\section{Estimated Effects of Certification}

We now turn to estimating the effect of a union winning NLRB certification across a range of outcomes using the panel of post-election observations. In the post-election sample, the median elapsed time is 4.7 years, with an average of 5.0 years and a standard deviation of 3.3 years. For each outcome $k$, we estimate the discontinuity $\tau_{k}$ in the expected value of characteristic $k$ across the threshold and interpret this as the effect of certification on that characteristic. For each $k$, we present estimates from the three specifications described above to assess sensitivity. Graphs corresponding to specification 1 in the pre- and post-election subsamples separately are also presented.

\subsection{Staffing levels}

Certification appears to reduce total staffing levels, particularly for NAs and RNs. Certification is estimated to causes NA staffing to fall by $-0.311(0.116)$ hours per resident-day in specification 1, which conditions only on vote share (Table 3 top row). The 95 percent confidence interval (CI) is [-0.540, -0.083]. Conditioning on each home's pre-election mean NA staffing level in specification 2 yields an estimated negative effect of -0.360 (0.118) HPRD. Conditioning on each home's pre-election means for all staffing, quality, other strategic margins, and market characteristics in specification 3 yields a stable estimate, -0.331 (0.114).

\footnotetext{
${ }^{13}$ These can be interpreted as intent-to-treat effects with noncompliance. We refrain from fuzzy RD analysis to get treatment-on-treated effects due to serious measurement error in the union "treatment" measure. While FMCS notices after the first post-certification year reliably indicate the presence of a union contract, the absence of such filing does not reliably indicate union absence.
} 
This is about a 15 percent effect against the post-election sample mean. Figure 3(a) shows the result corresponding to specification 1. Pre-election observations are considered in the left panel to test for pre-treatment discontinuity at the threshold. The pre-election discontinuity is small and insignificant, a difference of only 0.015 HPRD in NA staffing with standard error of 0.178 . Post-election observations are used in the right panel to help assess the union certification effect. After the election, the discontinuity is large and significant. It appears to be driven especially by differences at homes close to the cut-off rather than shifts across the whole range of vote-shares.

Estimates of effects on LPN staffing levels are also negative and stable across specifications, but small and insignificant (second row).

Estimates for effects on RN staffing (third row) are also negative and stable across specifications. Specification 1 yields a -0.278 (0.209) effect. As displayed in Figure 3(c), this postelection difference is only a little larger than the pre-election difference. To guard against a spurious finding driven by pre-election differences, specification 2 conditions on each home's pre-election mean RN staffing level. The estimated effect actually increases slightly to -0.317 (0.153) and becomes significant at 5 percent. Specification 3 adds the whole vector of preelection means to the conditioning set to adjust for any pre-election differences and yields an estimated effect of $-0.291(0.140)$, also significant at 5 percent. This corresponds to a large 50 percent difference in staffing levels. Given the pre-election difference, a hugely negative true effect does not seem plausible but the sum of evidence points to a negative effect on RN staffing. Comparing the pre- and post-election RN staffing levels shows that there was some secular reduction in RN staffing levels over time in both certified and uncertified homes. The drop appears especially large in homes where unions won elections with large majorities.

The negative estimated effects for NAs and RNs and the null for LPNs also hold under a full range of assumed parametric functional forms and bandwidths. Estimates using mean (zero-order) comparisons at $h=0.05$ and linear, quadratic, cubic, and quartic control functions at each bandwidth $0.15,0.25$, and 0.35 are presented in for NAs (Table A.2), for LPNs (Table A.3), for RNs (Table A.4), and for the other outcomes in Tables A.5 through A.12 in the Appendix. Negative point estimates for NAs and RNs show up across functional form and bandwidth assumptions, though magnitudes vary somewhat. ${ }^{14}$

Taken together, this analysis of direct-care staffing outcomes suggest that certification leads to reduced staffing levels in nursing homes with the largest and most precisely estimated effect on the employment of NA. This alone suggests a boost in the simplest measure of labor productivity: quantity of resident-days of care provided per hour of labor.

Because only a fraction of certifications lead to enduring unionization, unionization effects

\footnotetext{
${ }^{14}$ Within functional form and bandwidth, estimates are mostly stable across conditioning sets.
} 
are likely larger than these estimated certification effects. If one assumes certification has no effect except through unionization, then unionization effects could be estimated by scaling up the share of certifications that lead to enduring unionization. This would imply unionization effects are roughly double the estimated certification effects. The idea that the sign of certification and unionization effects are the same seems very credible. However, we suggest caution in embracing this precise interpretation of magnitudes because certification (or lack thereof) may operate through other channels besides unionization.

A reduction in staffing levels could be driven by positive effects of unionization on wages and other unit labor costs. This would be consistent with a right-to-manage model of union bargaining in which firms are free to choose employment levels based on the collectively bargained wage, and weighs against alternative models of efficient bargaining over both wages and employment, or firm monopsony, whereby employment need not decrease in response to higher wages (Pencavel, 1991; McDonald and Solow, 1981; Link and Landon, 1975; Manning, 2003). It is also consistent with new evidence against monopsony in the nursing home labor market for NAs (Matsudaira, forthcoming). Another part of the story could be that, in homes where unions just lose elections, management raises staffing levels in order to try to preempt a repeat organizing attempt. This could explain the post-election blip up for expected NA HPRD just below the threshold (Figure 3(a)).

Aside from differential wage effects, federal minimum staffing requirements could play a role in affecting unionization's impact across the different staffing classes. Federal law requires all homes to have an $\mathrm{RN}$ on duty at least 8 hours every day and to have a licensed nurse (RN or LPN) on duty the rest of the time. However, federal law has no requirements regarding NAs. Therefore, any nursing homes employing RNs more than 8 hours per day, when faced with increases in RN wages, might substitute towards less expensive LPNs.

\subsection{Quality}

Given that the nursing home literature generally links staffing levels to care quality, one might expect the decline in staffing levels to have a deleterious impact on the care quality. If so, it may be that unions reduce quality-adjusted productivity. In order to have a more complete view of the impact of certification on nursing homes we assess the union's impact on quality along both clinical and resident experience dimensions. ${ }^{15}$

\footnotetext{
${ }^{15}$ An obvious empirical strategy one might consider is to estimate the parameters of a production function in an RD framework. We decided not to pursue this possibility. In our context, at a minimum, we would want to specify an empirical quality production technology that allows for a hierarchical organizational structure (Simon and Barnard, 1976; Williamson, 1967; Rosen, 1992) and an additional, correlated technological unobservable beyond unobservables that affect union certification (Olley and Pakes, 1996). To the best of our knowledge, no one has estimated such a model. Even if estimating such a model were feasible given our
} 
Broadly, the point estimates suggests little impact on average care quality although these effects are imprecisely estimated. The estimates reported in Figures 4(a) to 4(c) show no significant differences across the threshold pre- or post-election in the total number of deficiencies, the presence of a severe deficiency, nor in homes' percentage of private-pay residents, those who are likely more responsive to and demanding of both care quality and the quality of the resident experience. Confidence intervals include both positive and negative changes in quality. Estimates for total deficiency count and the presence of a severe deficiency are relatively stable when pre-election characteristics are added to the conditioning sets (Table 3 rows 4 and 5). The sign of the percent private-pay effect point estimate goes from positive to negative. Evidence from the richest specification is mixed. The point estimate on severe deficiency suggests a positive quality effect but those on total deficiency count and percent private pay suggest a negative quality effect, and the total deficiency count estimate becomes significant at the 10 percent level. Overall, this mixed evidence suggests no large negative impact on quality but does not nail the question.

Digging deeper, we estimate union effects on the seven specific proxies for care quality listed in Table 4. These outcome measures are chosen because they are either particularly sensitive to labor quality, measure substitution (perhaps inappropriately) away from labor to technology when faced with higher labor costs, or are additional, direct evidence of care quality affects (Cawley et al., 2006). ${ }^{16}$ Consistent with the results presented above, we find little evidence of changes in care quality along these clinical dimensions. However, in general, these estimates are also imprecise. The results in Table 4 show no significant effects, with one exception: the percent of residents on psychoactive medications is about 4 percent lower in homes where unions win elections, off a base of 55 percent, which would indicate higher quality care. In order to improve precision, we also estimated a single, latent care-quality factor using these 7 variables as independent, noisy measures of quality. With this outcome and using specification 1 , certification is estimated to raise quality by $0.163(0.185)$ standard deviations, with a CI of $[-0.196,0.522]$. This also suggests that large reductions in staffing did not drive large reductions in quality but again the estimate is noisy.

data, it is beyond the scope of this paper to develop and estimate such a model.

${ }^{16}$ Urethral catheterization can lessen the need for staff to assist with toileting, but place the resident at greater risk for urinary tract infection, with other long-term complications including bladder and renal stones, abcesses, and renal failure. Immobility resulting from the use of physical restraints may increase the risk of pressure ulcers, depression, mental and physical deterioration, and mortality. Feeding tubes can result in complications including self-extubation, infections, aspiration, unintended misplacement of the tube, and pain. Overuse and misuse of psychoactive medications may result in mental and physical deterioration. Although many residents are bedfast or chairbound due to medical conditions, bedfast and chairbound residents are at a higher risk of developing pressure ulcers and other complications. Pressure ulcers are areas of the skin and underlying tissues that erode as a result of pressure or friction and/or lack of blood supply. 


\subsection{Other strategic margins}

If unionization leads homes to shift to a less severe case mix and the work becomes easier, then this might be confounded for a productivity increase. To assess this possibility, we estimate the effect of union certification on the facility resident acuity index. There is no evidence of a significant difference in residents' average acuity. Table 3 shows the estimate of -.188 (0.230) from specification 3, which which is statistically insignificant and small relative to both the mean (10.2) and standard deviation (1.5) of the patient acuity distribution. We also examine effects on total number of beds and the percentage of beds occupied, both of which measure potential adjustments to labor-capital ratios. We observe no significant effect of certification on either the total number of beds nor the occupancy rate. Here too, point estimates are small, precise, and insignificant. Graphs are in appendix Figures A.1(a), A.1(b), and A.1(c). ${ }^{17}$

\subsection{Productivity}

Combining our results on employment and the quality impact of certification allows us to examine the productivity impact of unionization. Specifically, if productivity is measured as quality-adjusted output (resident-days of care provided) per labor hour, then our results suggest that average productivity improved after union certification. Evidence below on payroll and occupancy rates suggest that productivity in terms of output per labor cost may also have increased. This is consistent with increases in productivity holding workers fixed (Duncan and Stafford, 1980; Freeman and Medoff, 1984; Perelman, 2011). Unionized nursing homes may also have a stronger incentive to invest in workers' human capital and provide additional training (Acemoglu and Pischke, 1999; Dustmann and Schönberg, 2009). It is also consistent with prior evidence that unionization in a two-sided selection process leads to negative selection for higher-skilled workers and positive selection for lower-skilled (Pettengill, 1979; Reynolds, 1986; Card, 1996; Hirsch and Schumacher, 1998).

This fundamental result is quite robust to specification choice. Because the estimate in each cell of Table 3 depends on a bandwidth choice chosen optimally for that regression, the bandwidths differ across cells (details in Table A.14). This approach uses the available information efficiently within regression but opens the possibility the negative staffing effect and null quality effect may be driven by differences in bandwidth. However, this does not appear to be the case. Table A.13 presents estimates analogous to those in Table 3 but holds the bandwidth fixed across all regressions $(h=0.12)$. Nothing changes meaningfully.

\footnotetext{
${ }^{17}$ We also investigated the impact of unionization on number of residents and found no effect.
} 


\subsection{Market structure and unionization}

The RD analysis suggests that union certification had no effect on the competitive structure of the local nursing home market but did increase union density. Unions may impact entry, exit, acquisition and investment strategies of homes and their competitors and thus impact market structure. However, the estimates in the bottom panel of Table 3 show estimated effects on the local HHI of near zero. Certification increases union density almost mechanically, because those homes where unions win elections are categorized as newly union in computing its market's post-election union density. However, it is interesting to note the magnitude of the estimate, as it suggests the average unionizing home holds about 10 percent of the beds in its county's market.

Finally, we do not find evidence that certification affects firm survival. ${ }^{18}$ Table 5 reports estimated effects on indicators of survival to 2005, to 5 years post-election and to 10 years post-election. All of the estimates are small relative to the dependent variable means, and none are significant. This finding is consistent with prior theoretical and empirical work (Freeman and Kleiner, 1999; DiNardo and Lee, 2004) and consistent with positive productivity effects.

\subsection{Evidence on mechanisms from earnings data}

To better understand the mechanisms underlying the estimated staffing level effects we focus on the subsample of homes represented in the Census's LEHD and LBD databases where confidential earnings data are available. Unfortunately, this shrinks the sample size further. The analysis has less power and our conclusions are less definitive. The estimates presented in this subsection are credibly unbiased given the research design, but are generally not statistically significant at conventional levels. In the 429-home Census subsample, the mean payroll is $\$ 5.4$ million paid to a mean of 216 employed individuals per home who earn an average of $\$ 20,871$ annually. ${ }^{19}$

Analysis of individual earnings suggests that union certification raises the earnings of stayers, individuals who remain employed at the nursing home post-election. The lower panel of Table 6 reports estimated effects on log earnings of about 0.1, although the estimates are

\footnotetext{
${ }^{18}$ We measure nursing home closure as failure to appear in the OSCAR data for three years, following Bowblis (2011). Given that inspections are mandated at least every 15 months, this is a conservative measure. As our OSCAR panel extends through 2007, we study survival to 2005 as as defined by an indicator measuring whether each home has any OSCAR observation in calendar years 2005, 2006, or 2007.

${ }^{19}$ The Census subsample resembles the main sample in terms of mean nursing home characteristics (Appendix Table A.15 versus Table 1) and effects on direct-care staffing levels, care quality, and other strategic margins (Appendix Table A.16 versus Table 3). In the subsample, there is also evidence of large negative effects on RN and NA staffing levels and no consistent evidence of declining care quality.
} 
imprecise. This suggests that unions may have raised the cost of labor on average for a given worker.

Nonetheless, estimates using LBD data suggest that total payroll and average earnings nonetheless did not increase at unionized homes. The upper panel of Table 6 reports estimates of the union effect on the log of total payroll, the log of total employment, the log of average earnings (the difference between the two) and the log of average wage (where average wage is payroll divided by FTE from the OSCAR data). The estimated union effects on employment and payroll are negative but not significantly different than zero.

Estimates of the individual earnings effect by initial earnings level suggest that the positive individual earning effects were concentrated at the lower end of the distribution, and effects at the top may have been negative, providing a possible explanation. Figure 5(a) shows estimates and confidence intervals of the union effect on log earnings for workers who remained employed by decile of the pre-election earnings distribution using RD analysis. The estimates are noisy, but are generally positive below the fifth decile, and are negative above the sixth, and significantly so at the tenth. A test of the hypothesis that the effects are equal above and below the fifth decile against the alternative that effects below are larger rejects at the 5 percent level. In light of these results, one interpretation of the staffing level effects is that higher-paid workers were more likely to leave nursing homes in response to the negative earnings effects, while lower-paid workers preferred to stay.

By contrasting the distribution of pre-election earnings for workers who remain employed at homes subsequent to a union victory with the distribution of pre-election earnings for workers who remain employed at homes subsequent to a union loss, we can develop direct evidence on the validity of this interpretation. Figure 5(b) plots the estimated pre-election log earnings density among stayers for homes that barely unionized and homes that barely did not. ${ }^{20}$ The figure shows unionized stayers are much more likely to come from the lower end of the distribution, and the difference is significant at the .01-level. Figure 5(c) on the other hand plots the estimated union and non-union pre-election earnings density for employees who left the nursing home. Employees who left a unionized home were much more likely to come from the upper end of the distribution than employees who left non-union homes. Note that there is no mechanical reason why the leavers' difference must be the reverse of the stayers' difference. These analyses show directly that the composition of workers at homes that unionized shifted toward workers who were at the lower end of the earnings distribution, both through retention and separation. For completeness, Figure 5(d) shows how unionization affected which workers came to the home after an election. Consistent

\footnotetext{
${ }^{20}$ The union (nonunion) estimated density is from local-linear density estimates using homes within $h$ above (below) the threshold, where $h$ is the mean-squared-error-optimal bandwidth.
} 
with the interpretation above, the figure shows workers that came to a unionized home were relatively more likely to be at the lower end of the post-election earnings distribution, although the difference is muted because it is combined with the causal effect on the earnings distribution, which is larger at the lower end.

\subsection{Effects by market characteristics and time horizon}

The impact of unionization may depend on the antecedents of local labor market union activity, the competitive environment, the regulatory environment and the amount of time the union has been active. Below we report the RD estimates by differences in these market and nursing home level characteristics.

Union density. Unions' ability to negotiate and enforce terms of employment depends on their strength in the local labor market, not just on being certified at a particular home. $\mathrm{RD}$ estimates suggests that the union reduction in staffing levels is concentrated in homes where the local market has below-median union density. Table 7 reports estimates similar to the ones in Table 3, but with the sample split according to whether pre-election union density in the home's market was above or below the median. The negative point estimates on RN and NA staffing are larger in magnitude in less unionized markets (top panel) than in more unionized markets (bottom panel). ${ }^{21}$ This suggests the unions are able to have larger effects where union density is lower. The results on quality look very similar in both types of markets suggesting that productivity may adjust smoothly.

In more highly unionized markets, unions have more power to support higher compensation levels. However, part of this ability comes from reducing competitive pressure on union firms by also raising compensation at nonunion firms in those markets. This occurs directly through raising market-clearing wages and indirectly through threat effects, which induce nonunion managers to try to match union standards in order to preempt employees' interest in unionizing. Therefore, in more unionized markets, there may be less scope for newly organized unions to raise wages. In this scenario, existing unions in more highly organized markets raise standards in nonunion firms, meaning their effects potentially pre-date unionization and would be under-estimated in the RD design.

Nursing-home market competitiveness. Unions' ability to extract economic rents from firms depends on the existence of rents in the firms. Because firms in less competitive markets may have more rents, we would expect to see bigger union effects in less competitive (higher HHI) markets (Abowd and Farber, 1990). Our RD estimates confirm this prediction, showing that the observed union effects are concentrated in less-competitive markets. Table 8 shows

\footnotetext{
${ }^{21}$ Bootstrap tests for difference in the specification 1 estimates show that only the difference in RN staffing is marginally significant $(\mathrm{p}=0.06)$.
} 
that for NA and RN HPRD, the negative employment effects are large and highly significant for homes with above-median HHI, but smaller and not significant in below-median HHI markets. ${ }^{22}$ For LPNs, the pattern runs in the other direction, but is not significant.

The evidence also suggests that certification leads to lower care quality in less competitive markets and perhaps higher quality care in more competitive ones. In more competitive markets, the likelihood of a severe deficiency decreases 18.9 (9.6) percent with certification and the point estimate on total deficiency count is negative, also consistent with higher quality of care. Negative employment effects accompanied by positive quality effects suggest positive productivity effects in more competitive markets. In contrast, in less competitive markets, where staff declines are sharper, the evidence suggests negative effects on care quality. Total deficiency counts go up by 2.93 (1.36) and the signs on private pay percentage and severe deficiency results are similarly signed. The effect on productivity in less competitive markets is ambiguous. Certification has significantly worse effects on two of the three quality measures in less competitive markets compared to more competitive markets: total deficiency count $(p=0.02)$ and percentage private-pay $(p=0.09)$. However, none of the differences in staffing level effects are significant. This finding strengthens the empirical foundation for an earlier literature that suggested more positive union productivity effects in more competitive product markets and more concern about negative productivity effects in less competitive product markets (Hirsch and Addison, 1986).

Another possible interpretation of this result comes from noting that product market competitiveness is likely correlated with labor market competitiveness, suggesting HHI may proxy for monopsony power in the labor market. In that case, this finding could be interpreted as supportive of a theoretical result in Section 12.5 of Manning (2003) that union wage mark-ups are likely higher in less competitive labor markets, assuming unions do not strongly prefer greater employment over higher wages.

Staffing regulations. Many states have legislated minimum staffing levels that are more stringent than the national standards. In order to explore the impact of these regulations on the impact of unionization, we classify state/year pairs as either having "strong" or "weak" staffing regulations based on the work of Harrington (2008) and estimate the impact of union certification for each sample. Strong regulatory states place floors on RNs and LPNs per resident and typically do not place as binding limits on the use of NAs. Unionization in the "strong" states should thus be primarily associated with significant declines in NAs as the regulations limit adjustments in RN and LPN staff. The results are presented in Table 9.

\footnotetext{
${ }^{22}$ Ideally, we would like to look at both HHI and union density simultaneously and in a statistical framework that allows for formal measurement of differences. However, given the limited sample size, this does not produce meaningful results.
} 
Consistent with the prediction, certification has a much larger (and statistically significant) impact on NAs in strong state-year nursing homes compared to weak state-year nursing homes. In weak regulatory regimes, the point estimates for NA and RN are all negative but imprecisely estimated.

Elapsed time. Union effects might grow over time, as the union becomes entrenched and the contract expands. On the other hand, the union might simply accelerate changes that would have occurred anyway. This relationship would produce a large effect early, which narrows over time (Freeman and Kleiner, 1990). To investigate this issue, we split the sample of observations at the median post-election elapsed time (4.6 years) to investigate shorter-run versus longer-run effects.

No large differences exist between short and long run effects. Table 10 presents shortrun estimates using only OSCAR observations soon after the election in the top panel and long-run estimates from observations in later years in the bottom panel. The negative NA employment point estimate increases in magnitude and the RN estimate diminishes somewhat. However, neither is statistically different. Looking at the long-run sample, there appears to be a marginally significant increase in total deficiencies. This differs from the result in the short-run and overall sample. It could be evidence of declines in care quality driven by greater decreases in RN staffing levels. However, neither of the other quality measures, private pay percentage nor presence of severe deficiency, confirms this story.

To summarize, certification appears to decrease employment of NAs and RNs but not LPNs. There is evidence of wage increases for lower-skilled workers. Although there are significant declines in employment, we do not observe change in the quantity or quality of nursing home care produced, nor do we see evidence that certification affects capital investment or nursing home survival. The effect of certification is enhanced in less dense union markets, in more concentrated markets, and when staffing regulations are more stringent.

\section{Conclusion}

This paper provides new evidence on the effects of unions on employment, product quality, and productivity in the increasingly important service sector, where little is known about union effects. Using a regression discontinuity design, we found robust evidence that certification leads to unionization in about half of certified homes and that certification causes a significant decline in staffing levels. We found no compelling evidence that certification resulted in reductions in the number of patients treated or quality of care although these estimates were imprecise. This finding points to unionization leading to increased labor productivity or, at least, not reduced labor productivity. The evidence we develop also 
suggests that unionization increases productivity among workers at the lower end of the wage distribution, which offsets the reduction in employment of higher wage occupations. This increase could occur as a benefit of better labor-management cooperation (Freeman and Medoff, 1984) or selection (Card, 1996). There is weaker, suggestive evidence that total payroll did not increase and that homes shift their occupational mix towards lower-paid, lower-skill occupations. These changes do not appear to harm firm growth or survival. We also observed stronger unionization effects in facilities in more-concentrated markets and in the least-unionized markets. The latter result is also consistent with large threat effects of unions in highly-unionized markets.

Increased labor productivity does not imply that management would invite unionization or that it could make the same changes unilaterally. Our findings are consistent with Lee and Mas (2009)'s finding of an imprecise, positive point estimated effect of certification on profits. ${ }^{23}$ First, increased labor productivity does not imply higher profits, especially if accompanied by higher wages. Second, managers and owners may also simply have a taste for more unilateral control over the workplace (Fehr, Herz and Wilkening, 2013) and may dislike unionization, to some extent, on these grounds. Third, a legally-binding collective bargaining agreement and the credible expectation of future bilateral bargaining may make certain productivity-enhancing commitments possible that would not otherwise be so, such as process improvements driven through labor-management dialogue (Freeman and Medoff, 1984; Cooke, 1992; Black and Lynch, 2001) and commitments to finance and share training costs (Acemoglu and Pischke, 1999).

Looking at the nursing home industry, although interesting in its own right, is important primarily because it can give insight into the role of unions in broader parts of the economy. Going forward, unions are likely to survive and expand primarily in non-tradeable sectors where the possibility of outsourcing is minimal and in sectors where organized workers can most directly use their political influence to shape the terms of market competition. Nursing homes exhibit both of these qualities. While much of the literature on union effects has focused on industries that are in decline both in the unionized sector and in the overall economy, the present and future of organized labor is in health care, education, public services, retail and other industries of this kind, to which our evidence from nursing homes is germane.

\footnotetext{
${ }^{23}$ They found negative effects on profits in the difference-in-difference analysis, driven by firms where unions won elections by wide margins. Our study does not examine that question.
} 


\section{References}

Abowd, J. and H. Farber, "Product Market Competition, Union Organizing Activity, and Employer Resistance," 1990. NBER Working Paper Number 3353.

Acemoglu, D. and J.-S. Pischke, "The Structure of Wages and Investment in General Training," Journal of Political Economy, 1999, 107 (3), 539-572.

Allen, J. E., Assisted Living Administration, Springer Publishing Company: New York, N.Y., 2004.

Bajari, Patrick, Han Hong, Minjung Park, and Robert Town, "Regression Discontinuity Designs with an Endogenous Forcing Variable and an Application to Contracting in Health Care," 2011. University of Minnesota manuscript.

Black, Sandra E and Lisa M Lynch, "How to compete: the impact of workplace practices and information technology on productivity," Review of Economics and statistics, 2001, $83(3), 434-445$.

Booth, Alison L., The economics of the trade union, Cambridge Univ Press: Cambridge, 1995.

Bowblis, John R., "Ownership Conversion and Closure in the Nursing Home Industry," Health Economics, 2011, 20 (6), 631-644.

Bronfenbrenner, Kate, Trade Union Renewal and Organizing, Continuum: London,

Card, David, "The Effect of Unions on the Structure of Wages: A Longitudinal Analysis," Econometrica, 1996, 64 (4), 957-979.

Cawley, John, David C. Grabowski, and Richard A. Hirth, "Factor Substitution in Nursing Homes," Journal of Health Economics, 2006, 25 (2), 234-247.

Cooke, William B., "Product Quality Improvement through Employee Participation," Industrial and Labor Relations Review, 1992, 46 (1), 119-134.

DiNardo, John and David S Lee, "Program evaluation and research designs," Handbook of Labor Economics, 2011, 4, 463-536.

DiNardo, John E. and David S. Lee, "Economic Impacts of New Unionization on Private Sector Employers: 1984-2001," Quarterly Journal of Economics, 2004, 119 (4), 1383-1441.

Duncan, Greg J. and Frank P. Stafford, "Do Unions Recieve Compensating Differentials," American Economic Review, 1980, 70 (3), 355-371.

Dustmann, Christian and Uta Schönberg, "Training and Union Wages," Review of Economics and Statistics, 2009, 91 (2), 363-376.

Fehr, Ernst, Holger Herz, and Tom Wilkening, "The Lure of Authority: Motivation and Incentive Effects of Power," American Economic Review, 2013, 103 (4), 1325-59. 
Ferguson, John-Paul, "Eyes of the Needles: A Sequential Model of Union Organizing Drives, 1999-2004," Industrial \&6 Labor Relations Review, 2008, 62 (3), 3-21.

Frandsen, Brigham, "Union Wage Setting and the Distribution of Employee Earnings: Evidence from Certification Elections," 2010. Massachusetts Institute of Technology manuscript.

Frandsen, Brigham R., "Party Bias in Union Representation Elections," 2013. Brigham Young University manuscript.

Freeman, Richard B. and James L. Medoff, What do unions do?, Basic Books: New York, N.Y., 1984.

_ and Morris M. Kleiner, "The Impact of New Unionization on Wages and Working Conditions," Journal of Labor Economics, 1990, pp. 8-25.

_ and _ , "Do Unions Make Enterprises Insolvent?," Industrial and Labor Relations Review, July 1999, 52 (4), 510-527.

Gertler, Paul J. and Donald M. Waldman, "Quality-Adjusted Cost Functions and Policy Evaluation in the Nursing Home Industry," Journal of Political Economy, 1992, pp. $1232-1256$.

Grabowski, D.C., J. Gruber, and J.J. Angelelli, "Nursing Home Quality as a Common Good," Review of Economics and Statistics, 2008, 90 (4), 754-764.

Hahn, J., P. Todd, and W. Van der Klaauw, "Identification and estimation of treatment effects with a regression-discontinuity design," Econometrica, 2001, 69 (1), 201-209.

Harrington, C., "Nursing Home Staffing Standards in State Statues and Regulations," 2008. University of California, San Francisco manuscript.

Helpman, E. and P.R. Krugman, Market structure and foreign trade, The MIT Press: Cambridge, Mass., 1987.

Hirsch, Barry T. and David A. Macpherson, "http://unionstats.com," 2011.

- and Edward J. Schumacher, "Unions, Wages, and Skills," Journal of Human Resources, 1998, 33 (1), 201-219.

Hirsch, B.T., "What Do Unions Do for Economic Performance?," Journal of Labor Research, 2004, 25 (3), 415-455.

_ and J.T. Addison, The economic analysis of unions: new approaches and evidence, Allen \& Unwin: London, 1986.

Holmes, T.J., "Geographic Spillover of Unionism," 2006. NBER Working Paper Number 12025. 
Imbens, G.W. and K. Kalyanaramang, "Optimal Bandwidth Choice for the Regression Discontinuity Estimator," 2009. NBER Working Paper Number 14726.

Konetzka, R. Tamara, Deokhee Yi, Edward C. Norton, and Kerry E. Kilpatrick, "Effects of Medicare Payment Changes on Nursing Home Staffing and Deficiencies," Health Services Research, 2004, 39 (3), 463-488.

Lee, David S. and Alexandre Mas, "Long-run Impacts of Unions on Firms: New Evidence from Financial Markets, 1961-1999," 2009. NBER Working Paper Number 14709.

_ and Thomas Lemieux, "Regression Discontinuity Designs in Economics," Journal of Economic Literature, 2010, 48 (2), 281-355.

Lewis, H.G., Unionism and relative wages in the United States: an empirical inquiry, University of Chicago Press: Chicago, Ill., 1963.

Link, Charles R. and John H. Landon, "Monopsony and Union Power in the Market for Nurses," Southern Economic Journal, 1975, 41 (4), 649-659.

Lu, Susan F., "Multitasking, Information Disclosure and Product Quality: Evidence from Nursing Homes," Journal of Economics and Management Strategy, forthcoming.

Manning, Alan, Monopsony in motion: Imperfect competition in labor markets, Princeton University Press: Princeton, N.J., 2003.

Matsudaira, Jordan, "Monopsony in the Low-Wage Labor Market? Evidence from Minimum Nurse Staffing Regulations," Review of Economics and Statistics, forthcoming.

McDonald, Ian M. and Robert M. Solow, "Wage Bargaining and Employment," American Economic Review, 1981, 71 (5), 896-908.

Mellow, Wesley, "Unionism and Wages: A Longitudinal Analysis," Review of Economics and Statistics, 1981, 63 (1), 43-52.

Mor, Vincent, Jacqueline Zinn, Joseph Angelelli, Joan M. Teno, and Susan C. Miller, "Driven to Tiers: Socioeconomic and Racial Disparities in the Quality of Nursing Home Care," Milbank Quarterly, 2004, 82 (2), 227-256.

Olley, G. Steven and Ariel Pakes, "The Dynamics of Productivity in the Telecommunications Equipment Industry," Econometrica, 1996, 64 (6), 1263-1297.

OMalley, A.J., D.J. Caudry, and D. C. Grabowski, "Predictors of Nursing Home Residents Time to Hospitalization," Health Services Research, 2011, 46 (1), 82-104.

Pencavel, J., Labor Markets Under Trade Unionism: Employment, Wages, and Hours, Basil Blackwater: Cambridge, Mass., 1991.

Perelman, M., "Retrospectives X-Efficiency," Journal of Economic Perspectives, 2011, 25 (4), 211-222. 
Pettengill, J.S., "Labour Unions and the Wage Structure: A General Equilibrium Approach," Review of Economic Studies, 1979, 46 (4), 675-693.

Reynolds, M.O., "Trade Unions in the Production Process Reconsidered," Journal of Political Economy, 1986, 94 (2), 443-447.

Rosen, S., "Authority, Control, and the Distribution of Earnings," Bell Journal of Economics, 1992, 13, 311-323.

Simon, H.A. and C.I. Barnard, Administrative behavior, Vol. 3, Cambridge Univ Press, 1976.

Sojourner, A.J., M.M. Chen, D.C. Grabowski, and R.J. Town, "Trends in Nursing Home Unionization," Inquiry, 2011, 47 (4).

Stewart, M.B., "Union Wage Differentials, Product Market Influences and the Division of Rents," Economic Journal, 1990, 100 (403), 1122-1137.

Williamson, O.E., "Hierarchical Control and Optimum Firm Size," The Journal of Political Economy, 1967, pp. 123-138.

Wunderlich, Gooloo S., Frank A. Sloan, and Carolyne K. Davis, Nursing staff in hospitals and nursing homes: Is it adequate?, National Academies Press, 1996. 


\section{Tables}

\begin{tabular}{|c|c|c|c|c|c|c|c|c|c|c|}
\hline & Mean & Std. Dev. & Min & Max & Obs. & Mean & Std. Dev. & Min & Max & Obs. \\
\hline \multicolumn{11}{|l|}{ NLRB election characteristics } \\
\hline Vote share & 0.029 & 0.195 & -0.475 & 0.475 & 627 & & & & & \\
\hline $1($ vote share $>0.50)$ & 0.558 & 0.497 & 0 & 1 & 627 & & & & & \\
\hline \multicolumn{11}{|c|}{ OSCAR nursing home characteristics } \\
\hline & \multicolumn{5}{|c|}{ All observations } & \multicolumn{5}{|c|}{ Post-election observations only } \\
\hline NA hours/resident day (HPRD) & 2.13 & 0.763 & 0 & 8 & 7942 & 2.123 & 0.718 & 0 & 8 & 5319 \\
\hline LPN HPRD & 0.773 & 0.528 & 0 & 8 & 7993 & 0.778 & 0.485 & 0 & 7.137 & 5334 \\
\hline RN HPRD & 0.558 & 0.803 & 0 & 7.914 & 7978 & 0.503 & 0.736 & 0 & 7.914 & 5332 \\
\hline Total deficiency count & 6.826 & 6.5 & 0 & 81 & 8045 & 6.87 & 5.978 & 0 & 81 & 5353 \\
\hline 1(severe deficiency) & 0.233 & 0.423 & 0 & 1 & 8045 & 0.265 & 0.442 & 0 & 1 & 5353 \\
\hline Pct. private pay & 22.622 & 17.641 & 0 & 100 & 8045 & 21.59 & 16.196 & 0 & 100 & 5353 \\
\hline Acuity index & 10.275 & 1.576 & 3 & 24.083 & 7971 & 10.22 & 1.536 & 3 & 24.083 & 5329 \\
\hline Total beds & 125.684 & 79.377 & 5 & 977 & 8045 & 124.74 & 73.111 & 5 & 976 & 5353 \\
\hline Pct. beds occupied & 84.837 & 19.272 & 0.207 & 100 & 8045 & 85.284 & 16.942 & 0.556 & 100 & 5353 \\
\hline HHI, in county & 0.152 & 0.195 & 0.003 & 1 & 8045 & 0.159 & 0.2 & 0.003 & 1 & 5353 \\
\hline Union density, private only & 31.102 & 26.744 & 0 & 100 & 8045 & 35.446 & 27.538 & 0 & 100 & 5353 \\
\hline Turnout & 86.571 & 9.07 & 45.833 & 100 & 8031 & 86.671 & 9.138 & 45.833 & 100 & 5344 \\
\hline Log(bargaining unit size) & 4.497 & 0.65 & 3.091 & 7.142 & 8031 & 4.479 & 0.616 & 3.091 & 7.142 & 5344 \\
\hline Log(number valid votes) & 4.347 & 0.652 & 2.996 & 7.066 & 8045 & 4.331 & 0.619 & 2.996 & 7.066 & 5353 \\
\hline
\end{tabular}

Table 1: Summary statistics 


\begin{tabular}{|c|c|c|c|c|c|}
\hline \multirow[b]{2}{*}{ Variables } & \multicolumn{5}{|c|}{ Vote share within $h$ of 0.50 threshold } \\
\hline & $h=0.05$ & $h=0.15$ & $h=0.25$ & $h=0.35$ & $h=0.50$ \\
\hline \multicolumn{6}{|l|}{ Staffing } \\
\hline NA HPRD & $\begin{array}{r}-.0584 \\
(0.111)\end{array}$ & $\begin{array}{l}-.058 \\
(0.182)\end{array}$ & $\begin{array}{r}-.0987 \\
(0.122)\end{array}$ & $\begin{array}{r}-.0204 \\
(0.222)\end{array}$ & $\begin{array}{l}-.137 \\
(0.111)\end{array}$ \\
\hline LPN HPRD & $\begin{array}{l}-.113 \\
(0.101)\end{array}$ & $\begin{array}{l}-.117 \\
(0.161)\end{array}$ & $\begin{array}{r}-.0307 \\
(0.106)\end{array}$ & $\begin{array}{l}.0529 \\
(0.217)\end{array}$ & $\begin{array}{r}-.0723 \\
(0.100)\end{array}$ \\
\hline RN HPRD & $\begin{array}{l}-.103 \\
(0.176)\end{array}$ & $\begin{array}{r}-.0872 \\
(0.231)\end{array}$ & $\begin{array}{r}.00984 \\
(0.173)\end{array}$ & $\begin{array}{r}.11 \\
(0.257)\end{array}$ & $\begin{array}{r}-.0321 \\
(0.151)\end{array}$ \\
\hline \multicolumn{6}{|l|}{ Quality } \\
\hline Total deficiency count & $\begin{array}{r}.349 \\
(0.853)\end{array}$ & $\begin{array}{r}-.264 \\
(1.09)\end{array}$ & $\begin{array}{l}.518 \\
(0.89)\end{array}$ & $\begin{array}{r}1.26 \\
(0.798)\end{array}$ & $\begin{array}{r}1.09 \\
(0.713)\end{array}$ \\
\hline 1(severe deficiency) & $\begin{array}{r}-.0584 \\
(0.111)\end{array}$ & $\begin{array}{l}-.058 \\
(0.182)\end{array}$ & $\begin{array}{r}-.0987 \\
(0.122)\end{array}$ & $\begin{array}{r}-.0204 \\
(0.222)\end{array}$ & $\begin{array}{l}-.137 \\
(0.111)\end{array}$ \\
\hline Prct. private pay & $\begin{array}{l}2.47 \\
(3.06)\end{array}$ & $\begin{array}{l}2.72 \\
(3.76)\end{array}$ & $\begin{array}{r}-.275 \\
(3.00)\end{array}$ & $\begin{array}{l}.148 \\
(2.58)\end{array}$ & $\begin{array}{r}-1.78 \\
(2.42)\end{array}$ \\
\hline \multicolumn{6}{|l|}{ Other strategic margins } \\
\hline Acuity index & $\begin{array}{l}-.181 \\
(0.276)\end{array}$ & $\begin{array}{r}-.0348 \\
(0.349)\end{array}$ & $\begin{array}{l}-.166 \\
(0.259)\end{array}$ & $\begin{array}{r}-.172 \\
(0.31)\end{array}$ & $\begin{array}{r}-.388 \\
(.23)^{*}\end{array}$ \\
\hline Number of beds & $\begin{array}{r}-8.63 \\
(26.4)\end{array}$ & $\begin{array}{r}-11 \\
(30.2)\end{array}$ & $\begin{array}{r}-7.96 \\
(22.6)\end{array}$ & $\begin{array}{r}2.67 \\
(19)\end{array}$ & $\begin{array}{l}.499 \\
(16.7)\end{array}$ \\
\hline Prct. beds occupied & $\begin{array}{r}.505 \\
(4.7)\end{array}$ & $\begin{array}{r}1.46 \\
(5.7)\end{array}$ & $\begin{array}{r}-2.25 \\
(4.35)\end{array}$ & $\begin{array}{r}-.671 \\
(3.7)\end{array}$ & $\begin{array}{r}-.162 \\
(3.45)\end{array}$ \\
\hline \multicolumn{6}{|l|}{ Market characteristics } \\
\hline Market HHI - same county & $\begin{array}{r}.0125 \\
(0.0301)\end{array}$ & $\begin{array}{l}.0786 \\
(0.124)\end{array}$ & $\begin{array}{r}-.00284 \\
(0.043)\end{array}$ & $\begin{array}{r}.123 \\
(0.205)\end{array}$ & $\begin{array}{l}.0234 \\
(0.072)\end{array}$ \\
\hline Union density, private only & $\begin{array}{r}-3.94 \\
(3.54)\end{array}$ & $\begin{array}{r}-4.86 \\
(4.6)\end{array}$ & $\begin{array}{r}-3.81 \\
(3.78)\end{array}$ & $\begin{array}{r}-5.36 \\
(3.48)\end{array}$ & $\begin{array}{l}-6.71 \\
(3.08)^{* *}\end{array}$ \\
\hline \multicolumn{6}{|l|}{ Election characteristics } \\
\hline Log(NLRB election unit size) & $\begin{array}{l}-.184 \\
(0.169)\end{array}$ & $\begin{array}{l}-.188 \\
(0.235)\end{array}$ & $\begin{array}{r}-.156 \\
(0.17)\end{array}$ & $\begin{array}{l}.0313 \\
(0.236)\end{array}$ & $\begin{array}{l}-.106 \\
(0.142)\end{array}$ \\
\hline Log(Valid votes cast in election) & $\begin{array}{l}-.207 \\
(0.167)\end{array}$ & $\begin{array}{l}-.206 \\
(0.232)\end{array}$ & $\begin{array}{r}-.168 \\
(0.17)\end{array}$ & $\begin{array}{l}.0122 \\
(0.239)\end{array}$ & $\begin{array}{l}-.125 \\
(0.144)\end{array}$ \\
\hline Number of homes observed & 131 & 350 & 483 & 576 & 626 \\
\hline Number of home-dates observed & 587 & 1,517 & 2,042 & 2,480 & 2,688 \\
\hline Number of home-date-outcomes observed & 6,986 & 18,077 & 24,350 & 29,574 & 32,053 \\
\hline Adjusted $\mathrm{R}^{2}$ & .526 & .602 & .628 & .639 & .645 \\
\hline Joint-null $F$-test $p$-value & .844 & .885 & .968 & .697 & .359 \\
\hline
\end{tabular}

Coefficient (within-home-correlation corrected SE) Significance: $\quad *: 10 \% \quad * *: 5 \% \quad * * *: 1 \%$. Each column presents discontinuity estimates from a separate system of first-order linear equations in vote share. Only observations from homes with vote share within $h$ of the 0.50 threshold are used. With $h=0.05$, this tests for a difference in means, as only one support point is used on each side of the threshold.

Table 2: Test for discontinuity in mean nursing home characteristics in pre-election panel 


\begin{tabular}{|c|c|c|c|}
\hline \multirow[b]{2}{*}{ Specification } & \multicolumn{3}{|c|}{ Estimates } \\
\hline & 1 & 2 & 3 \\
\hline \multicolumn{4}{|l|}{ Staffing } \\
\hline NA HPRD & $\begin{array}{l}-.311 \\
(.116) * * *\end{array}$ & $\begin{array}{l}-.360 \\
(.118) * * *\end{array}$ & $\begin{array}{l}-.331 \\
(.114) * *\end{array}$ \\
\hline LPN HPRD & $\begin{array}{r}-.072 \\
(.106)\end{array}$ & $\begin{array}{r}-.050 \\
(.068)\end{array}$ & $\begin{array}{r}-.043 \\
(.073)\end{array}$ \\
\hline RN HPRD & $\begin{array}{r}-.278 \\
(.209)\end{array}$ & $\begin{array}{l}-.317 \\
(.153) * *\end{array}$ & $\begin{array}{l}-.291 \\
(.140) * *\end{array}$ \\
\hline \multicolumn{4}{|l|}{ Quality } \\
\hline Total deficiency count & $\begin{array}{r}1.326 \\
(.897)\end{array}$ & $\begin{array}{l}.839 \\
(.837)\end{array}$ & $\begin{array}{c}1.609 \\
(.870) *\end{array}$ \\
\hline 1(severe deficiency) & $\begin{array}{r}-.067 \\
(.052)\end{array}$ & $\begin{array}{r}-.065 \\
(.052)\end{array}$ & $\begin{array}{r}-.048 \\
(.044)\end{array}$ \\
\hline Prct. private pay & $\begin{array}{l}2.633 \\
(3.908)\end{array}$ & $\begin{array}{l}-.971 \\
(2.220)\end{array}$ & $\begin{array}{r}-2.023 \\
(2.202)\end{array}$ \\
\hline \multicolumn{4}{|l|}{ Other strategic margins } \\
\hline Acuity index & $\begin{array}{r}-.177 \\
(.311)\end{array}$ & $\begin{array}{r}-.352 \\
(.242)\end{array}$ & $\begin{array}{r}-.188 \\
(.230)\end{array}$ \\
\hline Number of beds & $\begin{array}{r}-24.31 \\
(25.81)\end{array}$ & $\begin{array}{l}5.151 \\
(4.624)\end{array}$ & $\begin{array}{l}5.368 \\
(4.728)\end{array}$ \\
\hline Prct. beds occupied & $\begin{array}{l}3.143 \\
(4.584)\end{array}$ & $\begin{array}{l}2.334 \\
(3.851)\end{array}$ & $\begin{array}{l}2.081 \\
(3.724)\end{array}$ \\
\hline \multicolumn{4}{|l|}{ Market characteristics } \\
\hline Market HHI - same county & $\begin{array}{l}.051 \\
(.051)\end{array}$ & $\begin{array}{r}-.0004 \\
(.008)\end{array}$ & $\begin{array}{l}.003 \\
(.010)\end{array}$ \\
\hline Union density, private only & $\begin{array}{l}5.545 \\
(7.328)\end{array}$ & $\begin{array}{l}9.688 \\
(4.904) * *\end{array}$ & $\begin{array}{l}10.841 \\
\quad(3.557) * * *\end{array}$ \\
\hline \multicolumn{4}{|c|}{ Specification conditional on home's pre-election mean of: } \\
\hline This outcome variable & $\mathrm{N}$ & $\mathrm{Y}$ & $\mathrm{Y}$ \\
\hline All other outcome variables & $\mathrm{N}$ & $\mathrm{N}$ & $\mathrm{Y}$ \\
\hline
\end{tabular}

$\overline{\overline{\text { Coefficient (within-home cluster bootstrap SE). Significance: }} \quad *: 10 \% \quad * *: 5} \% \quad * * *: 1 \%$. Each cell presents discontinuity estimate from a separate local linear regression. Number of home-dates observed varies due to missing outcomes or conditioning values. Across outcomes, the range of number of homes observed is 626 to 627 (616 to 627 ) (610 to 611) in specification 1 (2) (3), including 5,319 to 5,353 (5,250 to 5,353$)(5,220$ to 5,245$)$ observed home-times. Optimal bandwidth and observations within it for each regression are in Table A.14.

Table 3: Estimated effects on nursing homes characteristics using post-election panel and local linear estimator 


\begin{tabular}{|c|c|c|c|c|}
\hline \multirow[b]{2}{*}{ Specification: } & \multicolumn{3}{|c|}{ Estimates } & \multirow[t]{2}{*}{$\begin{array}{c}\text { Post-election mean } \\
\text { of outcome }\end{array}$} \\
\hline & 1 & 2 & 3 & \\
\hline Prct. urethral catheter & $\begin{array}{l}-.817 \\
(1.441)\end{array}$ & $\begin{array}{r}-.933 \\
(.997)\end{array}$ & $\begin{array}{r}-.917 \\
(.956)\end{array}$ & 7.13 \\
\hline Prct. mobility restrained & $\begin{array}{r}.478 \\
(1.578)\end{array}$ & $\begin{array}{l}-.526 \\
(1.577)\end{array}$ & $\begin{array}{r}-1.415 \\
(1.584)\end{array}$ & 9.24 \\
\hline Prct. spc. feeding tube & $\begin{array}{l}-.580 \\
(1.738)\end{array}$ & $\begin{array}{l}-.206 \\
(1.043)\end{array}$ & $\begin{array}{r}.27 \\
(1.006)\end{array}$ & 6.90 \\
\hline Prct. psycho-active meds & $\begin{array}{c}-4.84 \\
(2.76) *\end{array}$ & $\begin{array}{c}-4.67 \\
(2.47) *\end{array}$ & $\begin{array}{r}-3.13 \\
(2.61)\end{array}$ & 56.43 \\
\hline Prct. skin pressure sores & $\begin{array}{r}-1.369 \\
(.97)\end{array}$ & $\begin{array}{r}-1.673 \\
(1.322)\end{array}$ & $\begin{array}{l}-.613 \\
(1.121)\end{array}$ & 7.77 \\
\hline Prct. bedfast & $\begin{array}{r}.123 \\
(1.052)\end{array}$ & $\begin{array}{r}-.217 \\
(.977)\end{array}$ & $\begin{array}{r}.26 \\
(.935)\end{array}$ & 4.79 \\
\hline Prct. mobility chair & $\begin{array}{r}.237 \\
(3.568)\end{array}$ & $\begin{array}{r}.07 \\
(3.485)\end{array}$ & $\begin{array}{l}1.412 \\
(2.992)\end{array}$ & 52.84 \\
\hline
\end{tabular}

Specification conditional on home's pre-election mean of:

This outcome variable $\quad \mathrm{N} \quad \mathrm{Y} \quad \mathrm{Y}$

All Table 3 variables $\quad \mathrm{N} \quad \mathrm{N} \quad \mathrm{Y}$

Coefficient (within-home cluster bootstrap SE). Significance: $\quad *: 10 \% \quad * *: 5 \% \quad * * *$ : $1 \%$. Each cell presents discontinuity estimate from a separate local linear regression. Number of home-dates observed varies due to missing outcomes or conditioning values. For all outcomes but pressure sores, the of number of homes-dates observed is 5,353 in specifications 1 and 2 and 5,245 in specification 3. For pressure sores, the number is $5,238(3,484)(3,417)$ in specification 1 (2) $(3)$. Optimal bandwidth and observations within it for each regression are in Table A.14.

Table 4: Estimated effects on nursing homes characteristics using post-election panel and local linear estimator 


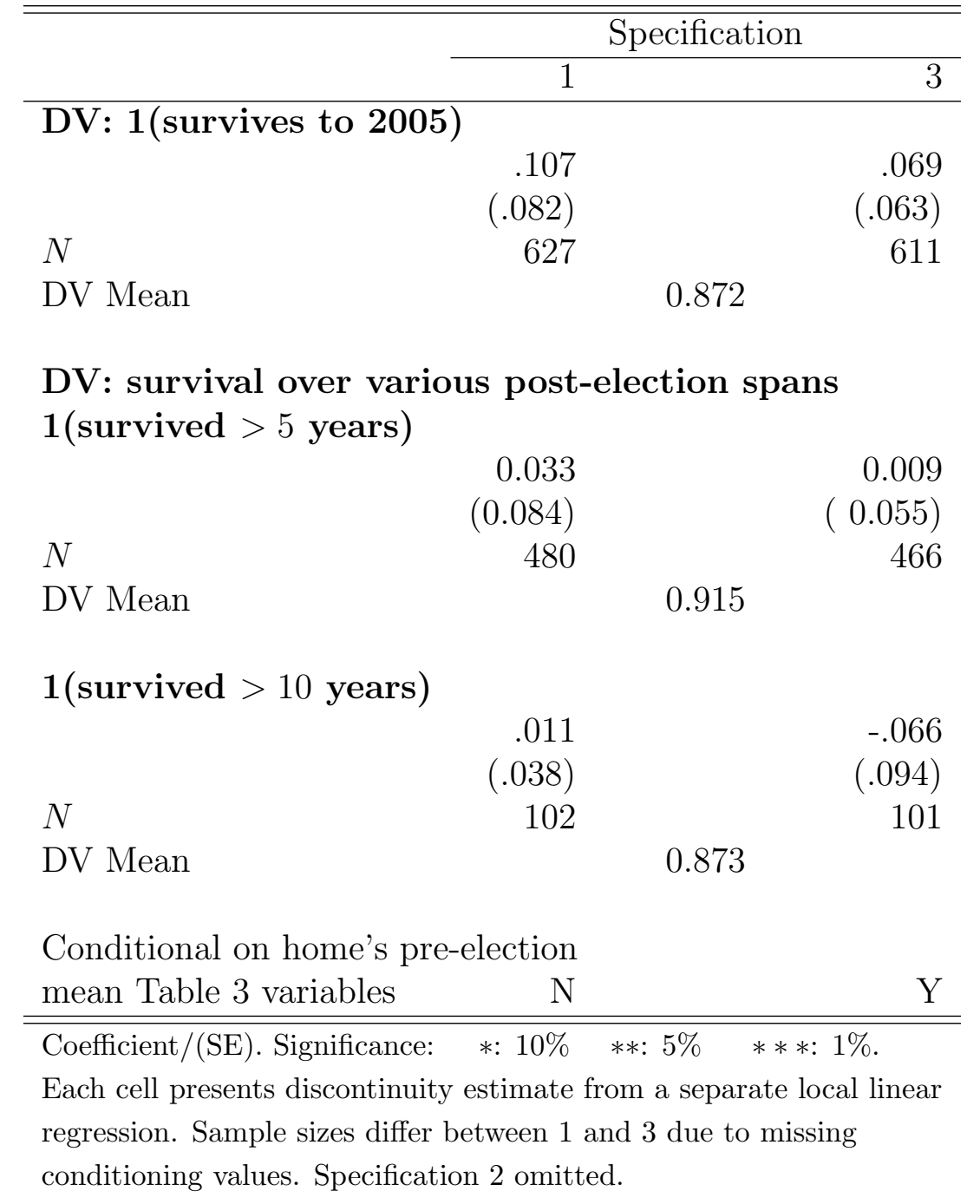

Table 5: Estimated effects on survival 


\begin{tabular}{lrrr}
\hline \hline Specification: & 1 & 2 & 3 \\
\cline { 2 - 4 } Outcome: & & & \\
\hline Home-quarter & -0.206 & -0.107 & -0.078 \\
$\log$ (payroll) & $(.342)$ & $(.114)$ & $(.116)$ \\
& -0.139 & -0.052 & 0.024 \\
$\log ($ employment) & $(.299)$ & $(.096)$ & $(.110)$ \\
& -0.083 & -0.127 & -0.111 \\
$\log ($ average earnings) & $(.083)$ & $(.059)$ & $(.075)$ \\
& 0.076 & -0.104 & -0.055 \\
$\log ($ average wages $)$ & $(.330)$ & $(.130)$ & $(.124)$
\end{tabular}

Employee-quarter for stayers

$\log ($ earnings gain)

0.127 undefined 0.094

(.118)

$(.529)$

Specification conditional on home's pre-election mean of:

$\begin{array}{llll}\text { This outcome variable } & \mathrm{N} & \mathrm{Y} & \mathrm{Y}\end{array}$

All Table 3 variables $\quad \mathrm{N} \quad \mathrm{N} \quad \mathrm{Y}$

Notes: The table reports local linear regression discontinuity estimates (standard errors) of the effect of a union victory on the dependent variable in the left-hand column. Average earnings are payroll/employment and average wages are payroll/FTE. Earnings gains are defined as the difference between an individual's post-election earnings and average pre-election earnings. All outcomes are from the LBD, except FTE from OSCAR and earnings gain from the LEHD.

Table 6: Estimated effects on earnings, payroll, and average wages in the Census subsample 


\begin{tabular}{lccc}
\hline \hline \multirow{2}{*}{ Specification } & \multicolumn{3}{c}{ Estimates } \\
\cline { 2 - 4 } Home in Less Unionized Nursing Home Markets (below & \multicolumn{2}{c}{3} \\
NA HPRD & -.418 & -.535 &.- .533 \\
& $(0.185) * *$ & $(0.196) * * *$ & $(0.219) * *$ \\
LPN HPRD & -.055 & -.056 & -.051 \\
& $(0.156)$ & $(0.084)$ & $(0.106)$ \\
RN HPRD & -.637 & -.610 & -.487 \\
& $(0.331) *$ & $(0.243) * *$ & $(0.252) *$ \\
Total deficiency count & .877 & 1.678 & 1.974 \\
& $(1.295)$ & $(1.202)$ & $(1.401)$ \\
1(severe deficiency) & -.045 & -.045 & -.033 \\
& $(0.060)$ & $(0.061)$ & $(0.065)$ \\
Prct. private pay & 2.987 & -2.029 & -4.207 \\
Acuity index & $(4.768)$ & $(3.019)$ & $(3.819)$ \\
Number of beds & .394 & -.134 &.- .377 \\
& $(0.491)$ & $(0.363)$ & $(0.432)$ \\
Prct. beds occupied & -14.887 & 3.433 & 6.475 \\
& $(29.86)$ & $(4.536)$ & $(5.164)$ \\
Market HHI - same county & 4.681 & 6.560 & 5.784 \\
Union density, private only & $(7.638)$ & $(4.856)$ & $(5.966)$ \\
& $(0.096)$ & -.0003 & -.010 \\
& 21.408 & 20.500 & $(0.020)$ \\
& $(8.230) * *$ & $(7.974) * * *$ & $(6.004) * * *$ \\
& & &
\end{tabular}

Home in More Unionized Nursing Home Markets (above median density) at Election

NA HPRD

LPN HPRD

RN HPRD

Total deficiency count

1 (severe deficiency)

Prct. private pay

Acuity index

Number of beds

Prct. beds occupied

Market HHI - same county

Union density, private only

$\begin{array}{rrr}(0.137) & (0.137) & (0.202) \\ -.107 & -.128 & -.034 \\ (0.125) & (0.108) & (0.137) \\ .124 & .071 & -.128 \\ (0.132) & (0.155) & (0.187) \\ .508 & -.069 & 1.005 \\ (1.203) & (1.264) & (1.474) \\ -.047 & -.038 & -.012 \\ (0.065) & (0.067) & (0.081) \\ 2.098 & -.627 & -2.154 \\ (4.393) & (2.882) & (6.170) \\ -.482 & -.525 & -.128 \\ (0.382) & (0.324) & (0.566) \\ -6.139 & 3.734 & 4.293 \\ (34.682) & (8.154) & (02.030) \\ -5.274 & -5.259 & -3.595 \\ (4.867) & (4.865) & (5.516) \\ -.026 & .003 & .007 \\ (0.041) & (0.005) & (0.007) \\ -3.588 & .593 & 2.014 \\ (8.432) & (6.394) & (8.390)\end{array}$

Specification conditional on home's pre-election mean of:

$\begin{array}{llll}\text { This outcome variable } & \mathrm{N} & \mathrm{Y} & \mathrm{Y} \\ \text { All other outcome variables } & \mathrm{N} & \mathrm{N} & \mathrm{Y}\end{array}$

$\overline{\overline{\text { Coefficient (within-home cluster bootstrap SE). Significance: }} *: 10 \% \quad * *: 5 \% \quad * * *:} 1 \%$. Each cell presents discontinuity estimate from a separate local linear regression and each column corresponds to a different set of control variables. Number of home-dates observed varies due to missing outcomes or conditioning values. Across outcomes, the range of number of homedates observed is 2,719 to 2,733 (2,695 to 2,733$)(2,681$ to 2,695$)$ in specification 1 (2) (3) in the top panel and 2,596 to 2,620 $(2,555$ to 2,620$)(2,534$ to 2,550$)$ in the bottom panel. Optimal bandwidth and observations within it for each regression are in Table A.14.

Table 7: Estimated effects by market's union density 


\begin{tabular}{|c|c|c|c|}
\hline \multirow[b]{2}{*}{ Specification } & \multicolumn{3}{|c|}{ Estimates } \\
\hline & 1 & 2 & 3 \\
\hline \multicolumn{4}{|c|}{ Home in More Competitive Nursing Home Markets (below median HHI) at Election } \\
\hline NA HPRD & $\begin{array}{r}-.237 \\
(0.170)\end{array}$ & $\begin{array}{r}-.230 \\
(0.153)\end{array}$ & $\begin{array}{r}-.188 \\
(0.163)\end{array}$ \\
\hline LPN HPRD & $(0.122) * *$ & $\begin{array}{c}-.160 \\
(0.085) *\end{array}$ & $\begin{array}{r}-.135 \\
(0.102)\end{array}$ \\
\hline RN HPRD & $\begin{array}{r}-.217 \\
(0.219)\end{array}$ & $\begin{array}{r}-.064 \\
(0.167)\end{array}$ & $\begin{array}{r}-.116 \\
(0.220)\end{array}$ \\
\hline Total deficiency count & $\begin{array}{c}-1.074 \\
(1.208)\end{array}$ & $\begin{array}{c}-1.464 \\
(1.193)\end{array}$ & $\begin{array}{r}-.444 \\
(1.437)\end{array}$ \\
\hline 1 (severe deficiency) & ${ }_{(0.077) * *}^{-165}$ & ${ }_{(0.085) * *}^{-.187}$ & ${ }^{-.189}$ \\
\hline Prct. private pay & $\begin{array}{c}9.453 \\
(5.662) *\end{array}$ & $\begin{array}{r}.789 \\
(3.261)\end{array}$ & $\begin{array}{r}-.327 \\
(4.265)\end{array}$ \\
\hline Acuity index & $\begin{array}{r}-.344 \\
(0.424)\end{array}$ & $\begin{array}{r}-.251 \\
(0.384)\end{array}$ & $\begin{array}{r}-.190 \\
(1.036)\end{array}$ \\
\hline Number of beds & $\begin{array}{r}-23.298 \\
(22.68)\end{array}$ & $\begin{array}{r}6.419 \\
(6.073)\end{array}$ & $\begin{array}{c}-2.614 \\
(8.040)\end{array}$ \\
\hline Prct. beds occupied & $\begin{array}{r}7.826 \\
(4.843)\end{array}$ & $\begin{array}{r}5.718 \\
(4.940)\end{array}$ & $\begin{array}{r}6.366 \\
(7.311)\end{array}$ \\
\hline Market HHI - same county & $\begin{array}{r}.007 \\
(0.007)\end{array}$ & $\begin{array}{c}-.0004 \\
(0.002)\end{array}$ & $\begin{array}{r}-.0003 \\
(0.003)\end{array}$ \\
\hline Union density, private only & $\begin{array}{r}.355 \\
(5.509)\end{array}$ & $\begin{array}{r}-1.098 \\
(3.586)\end{array}$ & $\begin{array}{r}-1.373 \\
(5.375)\end{array}$ \\
\hline
\end{tabular}

Home in Less Competitive Nursing Home Markets (above median HHI) at Election

NA HPRD

LPN HPRD

RN HPRD

Total deficiency count

1 (severe deficiency)

Prct. private pay

Acuity index

Number of beds

Prct. beds occupied

Market HHI - same county

Union density, private only

$\begin{array}{ccc}(0.156) * * & (0.160) * * * & (0.216) * * \\ .092 & .011 & .005 \\ (0.147) & (0.106) & (0.118) \\ -.344 & -.560 & -.470 \\ (0.285) & (0.270) * * & (0.236) * * \\ 3.056 & 2.500 & 2.927 \\ (1.240) * * & (1.306) * * & (1.363) * * \\ .036 & .038 & .018 \\ (0.063) & (0.064) & (0.065) \\ -4.090 & -4.100 & -3.836 \\ (5.142) & (3.469) & (3.293) \\ -.264 & -.739 & -.402 \\ (0.491) & (0.378) * * & (0.412) \\ -20.69 & 1.644 & 3.534 \\ (33.933) & (6.333) & (6.156) \\ -1.883 & -.655 & -2.013 \\ (6.556) & (4.935) & (5.232) \\ .044 & .003 & .002 \\ (0.081) & (0.014) & (0.019) \\ 8.990 & 18.033 & 16.348 \\ (10.872) & (7.887) * * & (7.587) * *\end{array}$

Specification conditional on home's pre-election mean of:

$\begin{array}{llll}\text { This outcome variable } & \mathrm{N} & \mathrm{Y} & \mathrm{Y} \\ \text { All other outcome variables } & \mathrm{N} & \mathrm{N} & \mathrm{Y}\end{array}$

$\overline{\overline{\text { Coefficient (within-home cluster bootstrap SE). Significance: }} *: 10 \% \quad * *: 5 \% \quad * * *:} 1 \%$. Each cell presents discontinuity estimate from a separate local linear regression and each column corresponds to a different set of control variables. Number of home-dates observed varies due to missing outcomes or conditioning values. Across outcomes, the range of number of homedates observed is 2,513 to $2,531(2,478$ to 2,531$)(2,478$ to 2,486$)$ in specification 1 (2) (3) in the top panel and 2,806 to 2,822 $(2,772$ to 2,822$)(2,745$ to 2,759$)$ in the bottom panel. Optimal bandwidth and observations within it for each regression are in Table A.14.

Table 8: Estimated effects by product market competitiveness 


\begin{tabular}{|c|c|c|c|}
\hline \multirow[b]{2}{*}{ Specification } & \multicolumn{3}{|c|}{ Estimates } \\
\hline & 1 & 2 & 3 \\
\hline Observations in State-Years & with Strong & N/LPN Sta & g Regulation \\
\hline NA HPRD & $(.352) * *$ & $\begin{array}{l}-.405 \\
(.151) * * *\end{array}$ & $\begin{array}{l}-.371 \\
(.151) * *\end{array}$ \\
\hline LPN HPRD & $\begin{array}{l}-.089 \\
(.113)\end{array}$ & $\left(\begin{array}{l}-.108 \\
.106)\end{array}\right.$ & $\begin{array}{l}-.095 \\
(.104)\end{array}$ \\
\hline RN HPRD & $\begin{array}{l}-.032 \\
(.254)\end{array}$ & $\begin{array}{l}-.153 \\
(.200)\end{array}$ & $\begin{array}{l}-.202 \\
(.192)\end{array}$ \\
\hline Total deficiency count & $\begin{array}{r}.363 \\
(1.000)\end{array}$ & $\begin{array}{r}.586 \\
(.991)\end{array}$ & $\begin{array}{l}1.333 \\
(.944)\end{array}$ \\
\hline 1 (severe deficiency) & $\begin{array}{l}-.068 \\
(.054)\end{array}$ & $\begin{array}{l}-.067 \\
(.055)\end{array}$ & $\begin{array}{l}-.033 \\
(.060)\end{array}$ \\
\hline Prct. private pay & $\begin{array}{r}5.135 \\
(4.382)\end{array}$ & $\begin{array}{r}.274 \\
(2.846)\end{array}$ & $\begin{array}{l}-1.825 \\
(2.890)\end{array}$ \\
\hline Acuity index & $\begin{array}{l}-.266 \\
(.393)\end{array}$ & $\begin{array}{l}-.446 \\
(.316)\end{array}$ & $\begin{array}{l}-.071 \\
(.317)\end{array}$ \\
\hline Number of beds & $\begin{array}{l}-23.182 \\
(25.639)\end{array}$ & $\begin{array}{l}-2.329 \\
(5.630)\end{array}$ & $\begin{array}{l}-1.274 \\
(3.924)\end{array}$ \\
\hline Prct. beds occupied & $\begin{array}{r}6.824 \\
(6.485)\end{array}$ & $\begin{array}{r}6.190 \\
(4.752)\end{array}$ & $\begin{array}{r}6.899 \\
(4.784)\end{array}$ \\
\hline Market HHI - same county & $\begin{array}{r}.015 \\
(.043)\end{array}$ & $\begin{array}{r}.003 \\
(.005)\end{array}$ & $\begin{array}{r}.006 \\
(.007)\end{array}$ \\
\hline Union density, private only & $\begin{array}{r}2.971 \\
(7.753)\end{array}$ & $\begin{array}{r}5.006 \\
(4.113)\end{array}$ & $\begin{array}{c}6.698 \\
(3.984) *\end{array}$ \\
\hline
\end{tabular}

Observations in State-Years with Weak RN/LPN Staffing Regulation

$\begin{array}{lrrr}\text { NA HPRD } & (.194) & (.168) & (.268) \\ \text { LPN HPRD } & . .051 & .045 & .053 \\ & (.204) & (.078) & (.283) \\ \text { RN HPRD } & -.550 & -.414 & -. .375 \\ & (.324) * & (.199) * * & (.865) \\ \text { Total deficiency count } & 2.054 & .158 & .828 \\ & (1.584) & (1.748) & (4.270) \\ \text { 1(severe deficiency) } & . .002 & .005 & -.019 \\ & (.079) & (.078) & (.232) \\ \text { Prct. private pay } & -2.687 & -2.194 & -3.974 \\ & (5.021) & (3.753) & (17.703) \\ \text { Acuity index } & -.400 & -.473 & (. .498 \\ & (.499) & (.487) & (.721) \\ \text { Number of beds } & 19.657 & 6.801 & 3.956 \\ & (47.458) & (6.706) & (10.597) \\ \text { Prct. beds occupied } & -7.227 & -6.307 & -8.562 \\ \text { Market HHI - same county } & (5.241) & (5.027) & (11.836) \\ & (.095 & -.009 & (.015) \\ \text { Union density, private only } & 7.996 & (.019) & (.105) \\ & (13.836) & (10.088) * & (13.429 \\ & & & \end{array}$

Specification conditional on home's pre-election mean of:

This outcome variable $\quad \mathrm{N} \quad \mathrm{Y} \quad \mathrm{Y}$ $\begin{array}{llll}\text { All other outcome variables } & \mathrm{N} & \mathrm{N} & \mathrm{Y}\end{array}$

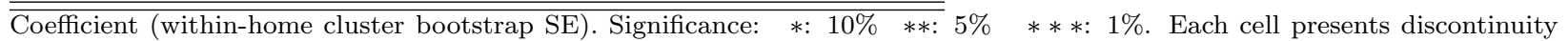
estimate from a separate local linear regression and each column corresponds to a different set of control variables. Number of home-dates observed varies due to missing outcomes or conditioning values. Across outcomes, the range of number of homedates observed is 3,585 to 3,605 (3,545 to 3,605$)(3,529$ to 3,544$)$ in specification 1 (2) (3) in the top panel and 1,734 to 1,748 $(1,705$ to 1,748$)(1,689$ to 1,701$)$ in the bottom panel. Optimal bandwidth and observations within it for each regression are in Table A.14.

Table 9: Estimated effects by strength of state RN/LPN staffing regulation 


\begin{tabular}{|c|c|c|c|}
\hline \multirow[b]{2}{*}{ Specification } & \multicolumn{3}{|c|}{ Estimates } \\
\hline & 1 & 2 & 3 \\
\hline \multicolumn{4}{|c|}{ Short-run effects: observations less than median elapsed time (4.6 years) past election } \\
\hline NA HPRD & $\begin{array}{c}-.333 \\
(0.163) * *\end{array}$ & $\begin{array}{c}-.350 \\
(0.135) * * *\end{array}$ & $(0.134) * *$ \\
\hline LPN HPRD & $\begin{array}{r}-.090 \\
(0.136)\end{array}$ & $\begin{array}{r}-.061 \\
(0.083)\end{array}$ & $\begin{array}{r}-.042 \\
(0.075)\end{array}$ \\
\hline RN HPRD & $\begin{array}{r}-.307 \\
(0.258)\end{array}$ & $\begin{array}{c}-.282 \\
(0.171) *\end{array}$ & $\begin{array}{r}-.236 \\
(0.152)\end{array}$ \\
\hline Total deficiency count & $\begin{array}{r}.593 \\
(1.001)\end{array}$ & $\begin{array}{r}-.065 \\
(0.876)\end{array}$ & $\begin{array}{r}.512 \\
(0.896)\end{array}$ \\
\hline 1 (severe deficiency) & $\begin{array}{r}-.078 \\
(0.073)\end{array}$ & $\begin{array}{r}-.070 \\
(0.074)\end{array}$ & $\begin{array}{r}-.046 \\
(0.060)\end{array}$ \\
\hline Prct. private pay & $\begin{array}{r}-.737 \\
(3.905)\end{array}$ & $\begin{array}{l}-2.135 \\
(2.237)\end{array}$ & $\begin{array}{l}-3.341 \\
(2.200)\end{array}$ \\
\hline Acuity index & $\begin{array}{r}-.165 \\
(0.359)\end{array}$ & $\begin{array}{r}-.296 \\
(0.267)\end{array}$ & $\begin{array}{r}-.044 \\
(0.241)\end{array}$ \\
\hline Number of beds & $\begin{array}{l}-18.729 \\
(28.978)\end{array}$ & $\begin{array}{l}11.296 \\
(4.804) * *\end{array}$ & $\begin{array}{c}9.624 \\
(4.949) *\end{array}$ \\
\hline Prct. beds occupied & $\begin{array}{r}1.728 \\
(5.235)\end{array}$ & $\begin{array}{r}1.164 \\
(3.687)\end{array}$ & $\begin{array}{r}.210 \\
(3.348)\end{array}$ \\
\hline Market HHI - same county & $\begin{array}{r}.046 \\
(0.045)\end{array}$ & $\begin{array}{r}.007 \\
(0.008)\end{array}$ & $\begin{array}{r}.011 \\
(0.009)\end{array}$ \\
\hline Union density, private only & $\begin{array}{r}8.462 \\
(6.441)\end{array}$ & $\begin{array}{l}11.058 \\
(4.165) * * *\end{array}$ & $\begin{array}{l}12.109 \\
(3.249) * * *\end{array}$ \\
\hline
\end{tabular}

Long-run effects: observations more than median elapsed time (4.6 years) past election

NA HPRD

LPN HPRD

RN HPRD

Total deficiency count

1 (severe deficiency)

Prct. private pay

Acuity index

Number of beds

Prct. beds occupied

Market HHI - same county

Union density, private only

$\begin{array}{ccc}(0.129) * * & (0.128) * * & (0.149) * \\ -.029 & -.049 & -.051 \\ (0.099) & (0.080) & (0.073) \\ -.131 & -.305 & -.318 \\ (0.170) & (0.153) * * & (0.129) * * \\ 1.848 & 1.593 & 2.546 \\ (1.103) * & (1.084) & (1.182) * * \\ -.056 & -.056 & -.033 \\ (0.053) & (0.051) & (0.057) \\ 1.885 & -1.296 & -.176 \\ (4.128) & (2.759) & (2.688) \\ -.178 & -.375 & -.269 \\ (0.330) & (0.302) & (0.284) \\ -29.470 & -1.161 & 2.660 \\ (21.108) & (6.805) & (5.498) \\ 3.010 & 2.372 & 3.411 \\ (5.515) & (4.555) & (4.423) \\ .053 & -.005 & -.001 \\ (0.062) & (0.011) & (0.012) \\ 2.714 & 8.053 & 8.570 \\ (7.974) & (6.123) & (5.217) * \\ & & \end{array}$

Specification conditional on home's pre-election mean of:

$\begin{array}{llll}\text { This outcome variable } & \text { N } & \text { Y } & \text { Y } \\ \text { All other outcome variables } & \text { N } & \text { N } & \text { Y }\end{array}$

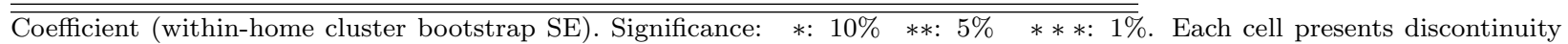
estimate from a separate local linear regression and each column corresponds to a different set of control variables. Number of home-dates observed varies due to missing outcomes or conditioning values. Across outcomes, the range of number of homedates observed is 2,652 to 2,676 (2,618 to 2,676$)(2,593$ to 2,617$)$ in specification 1 (2) (3) in the top panel and 2,667 to 2,667 $(2,632$ to 2,677$)(2,620$ to 2,628$)$ in the bottom panel. Optimal bandwidth and observations within it for each regression are in Table A.14.

Table 10: Estimated effects by elapsed time since election 


\section{$7 \quad$ Figures}

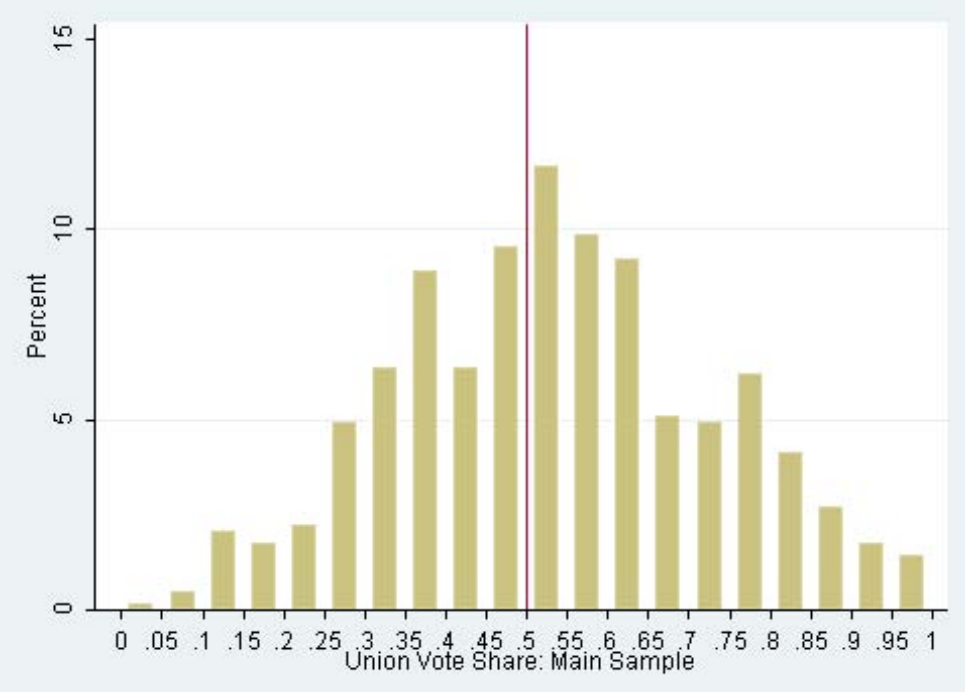

Figure 1: Density of election vote shares in main sample $(N=627)$.

Outcome: 1(any FMCS filing 1+ year post-election)

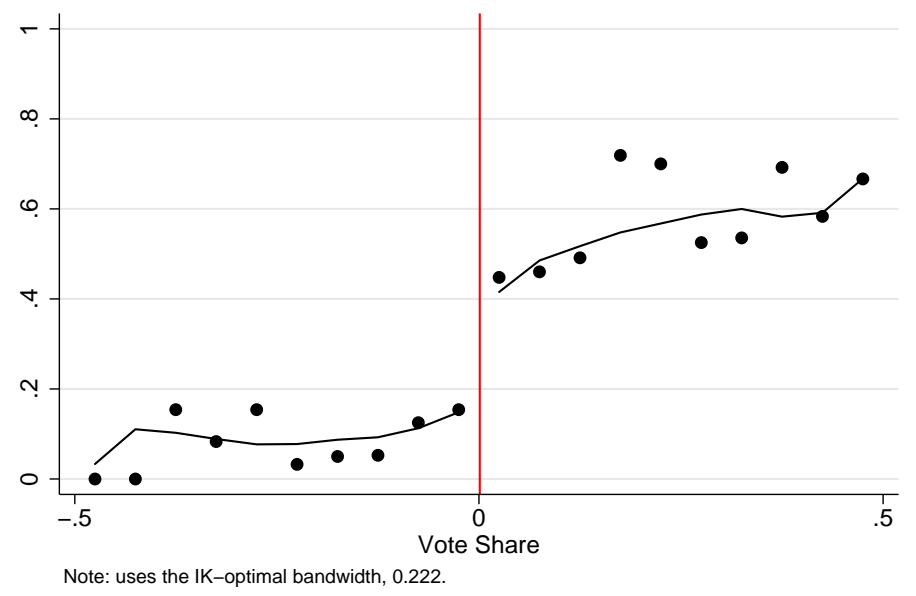

Figure 2: Expectation of indicator for any FMCS notice filed at least one year after focal NLRB election by vote share. Means of the indicator variable by vote share bin are plotted. Estimated expectation from local-linear regression on either side of the threshold using the IK-optimal bandwidth is graphed. 


\section{Outcome: NA HPRD}

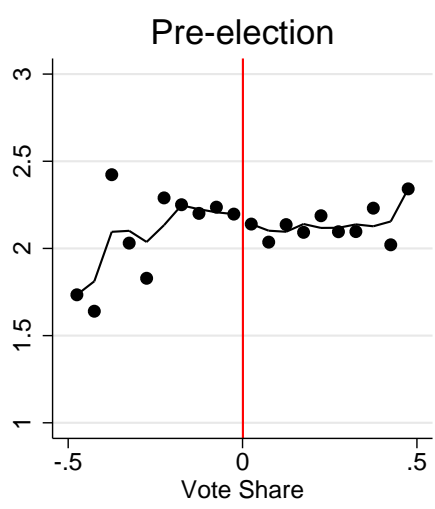

Disc. estim. (SE): .015 (.178)

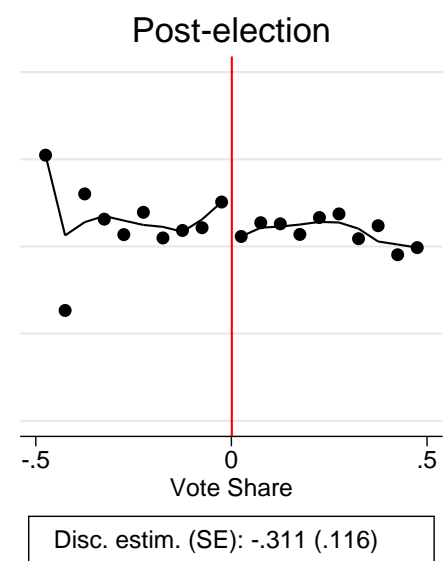

Note: both use the IK-optimal bandwidth for post-election sample: 0.093

\section{Outcome: LPN HPRD}
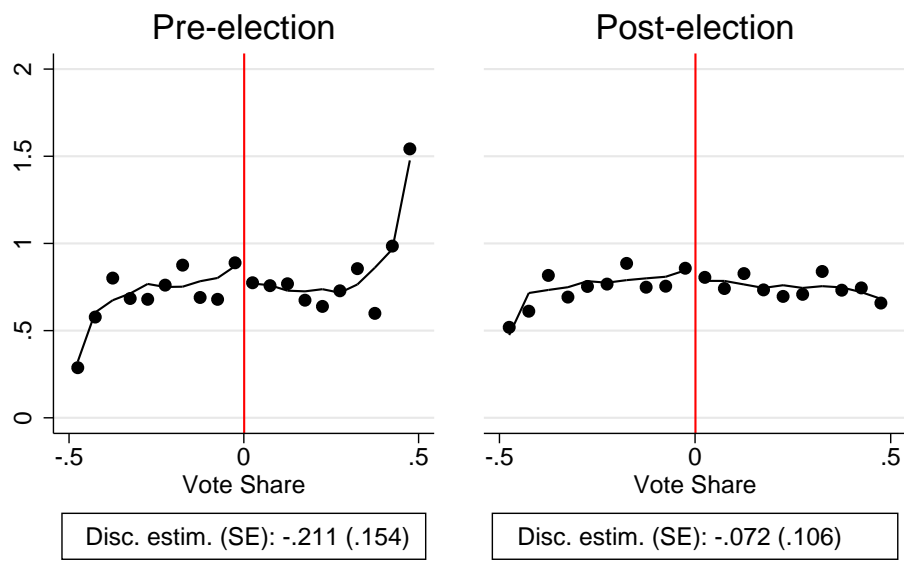

Note: both use the IK-optimal bandwidth for post-election sample: 0.1

(b)

(a)

Outcome: RN HPRD
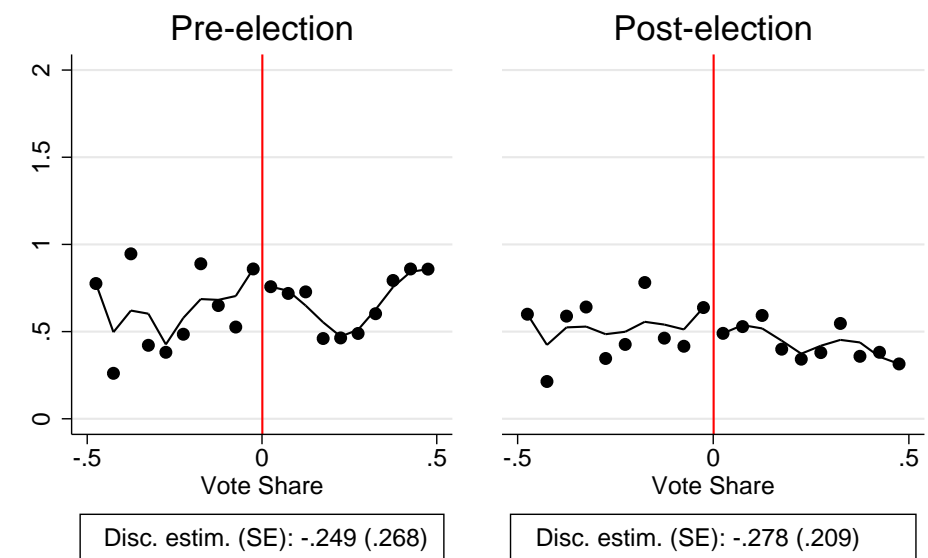

Note: both use the IK-optimal bandwidth for post-election sample: 0.096 .

(c)

Figure 3: Staffing levels: expected nurse aide (NA), licensed practical nurse (LPN), and registered nurse (RN) hours per resident-day (HPRD) by vote share bin in the pre- and post-election periods are plotted. Estimated expectations from locallinear regression on either side of the threshold using the IK-optimal bandwidth as in specification 1 of Table 3 is graphed. 
Outcome: Total deficiency count

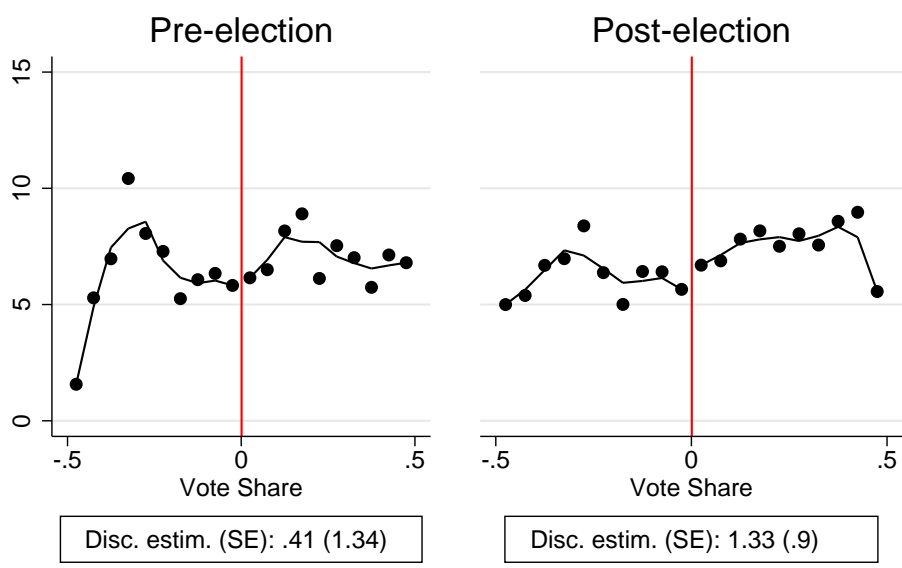

Note: both use the IK-optimal bandwidth for post-election sample: 0.095 .

(a)
Outcome: 1 (severe deficiency)
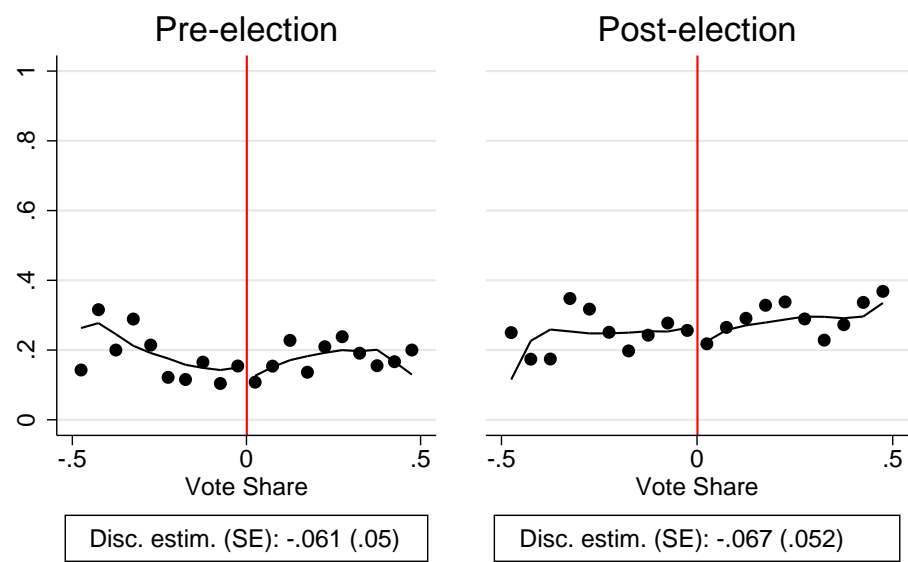

Note: both use the IK-optimal bandwidth for post-election sample: 0.203

(b)

Outcome: Pct. private pay
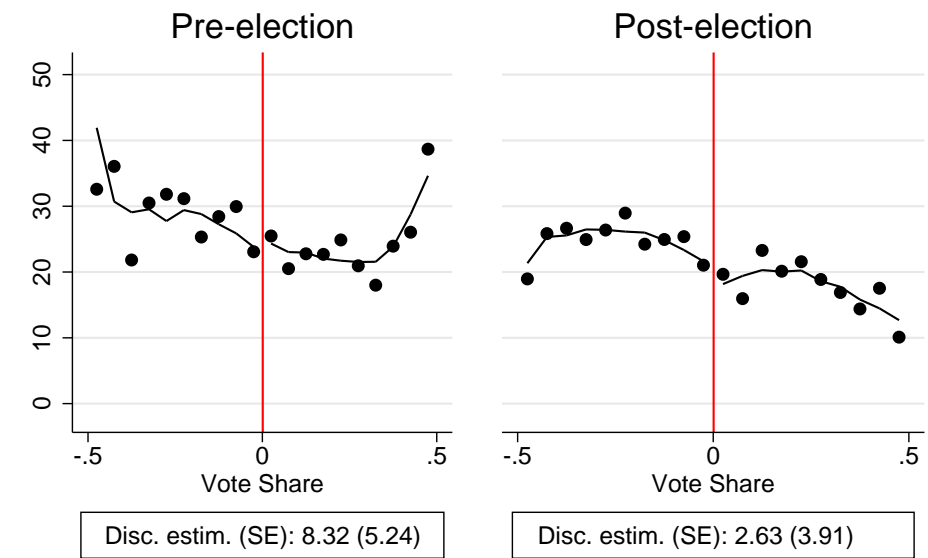

Note: both use the IK-optimal bandwidth for post-election sample: 0.102 .

(c)

Figure 4: Care quality: expected total deficiency counts, indicator that a severe deficiency present, and percentage of residents private-pay by vote share bin in the pre- and post-election periods are plotted. Estimated expectations from local-linear regression on either side of the threshold using the IK-optimal bandwidth as in specification 1 of Table 3 is graphed. 


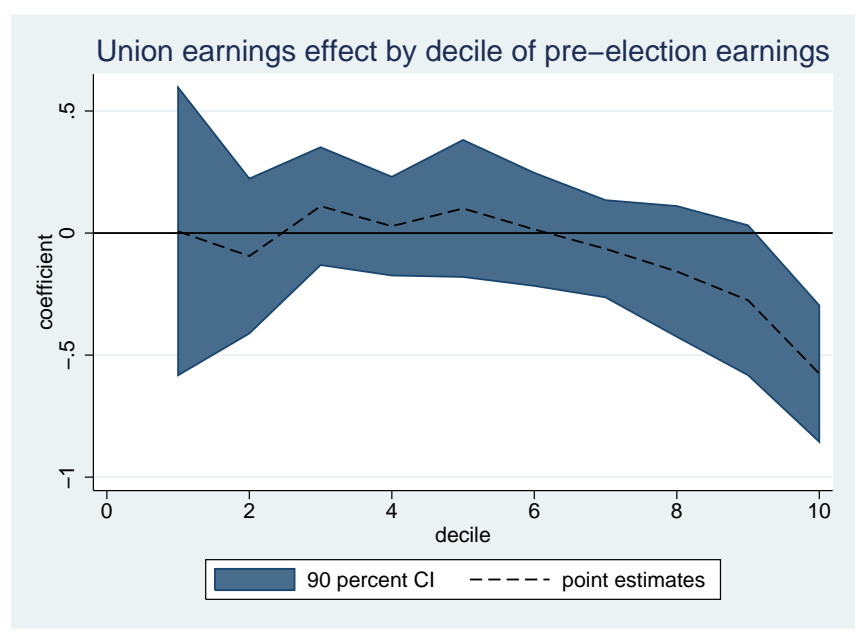

(a)

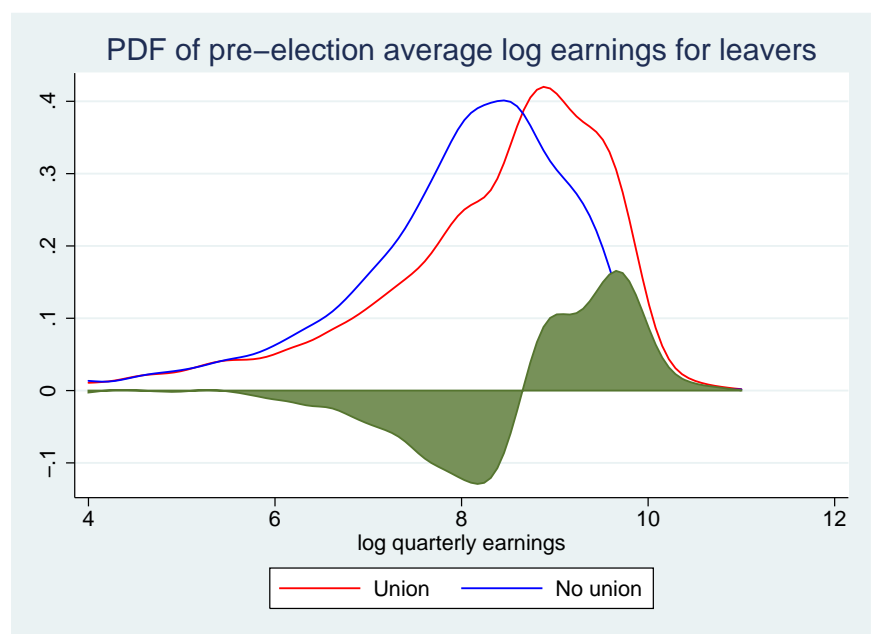

(c)

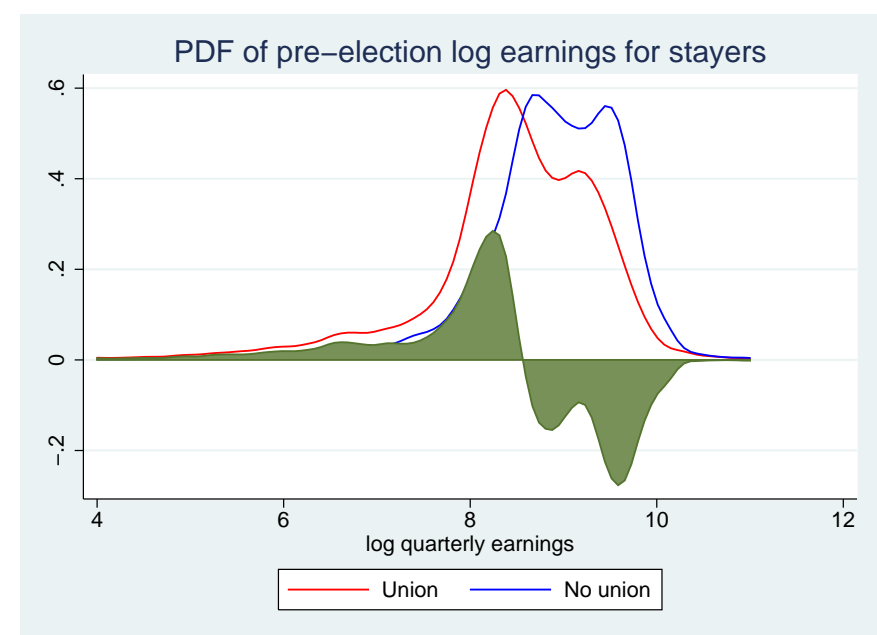

(b)

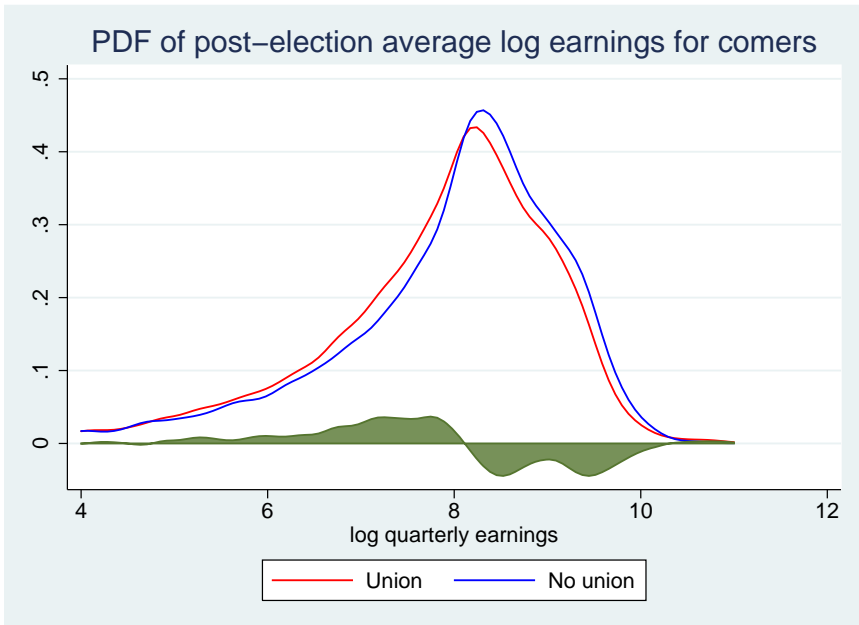

(d)

Figure 5: How does unionization affect selection and earnings? Subfigure 5(a) presents the local-linear estimates of effect of unionization on post-election earnings among employees who continue working at the home in the calendar quarter after the election (stayers) by pre-election earnings decile. Subfigure 5(b) presents local-linear estimates of densities of pre-election earnings for stayers at homes where unions just win elections and homes where unions just lose, as well as the difference between the distributions. Subfigure 5(c) does the same for those who leave the home. Subfigure 5(d) does the same for post-election earnings for those who begin employment at the home after the election. 


\section{A For Online Publication - Web Appendix}

Impacts of Unionization on Quality and Productivity

by Sojourner, Frandsen, Town, Grabowski, \& Chen

March 19, 2014 


\section{A.1 Tables}

\begin{tabular}{|c|c|c|c|c|c|}
\hline \multirow[b]{2}{*}{ Variables } & \multicolumn{5}{|c|}{ Vote share within $h$ of 0.50 threshold } \\
\hline & $h=0.05$ & $h=0.15$ & $h=0.25$ & $h=0.35$ & $h=0.50$ \\
\hline \multicolumn{6}{|l|}{ Staffing } \\
\hline NA HPRD & $\begin{array}{r}-0.058 \\
(0.111)\end{array}$ & $\begin{array}{r}-0.26 \\
(2.86)\end{array}$ & $\begin{array}{r}0.058 \\
(1.63)\end{array}$ & $\begin{array}{l}-1.9 \\
(1.47)\end{array}$ & $\begin{array}{r}0.254 \\
(1.16)\end{array}$ \\
\hline LPN HPRD & $\begin{array}{l}-.113 \\
(0.101)\end{array}$ & $\begin{array}{r}-.309 \\
(2.82)\end{array}$ & $\begin{array}{r}.128 \\
(1.6)\end{array}$ & $\begin{array}{l}-1.8 \\
(1.44)\end{array}$ & $\begin{array}{r}.32 \\
(1.14)\end{array}$ \\
\hline RN HPRD & $\begin{array}{l}-.103 \\
(0.176)\end{array}$ & $\begin{array}{l}-.27 \\
(2.84)\end{array}$ & $\begin{array}{l}.166 \\
(1.62)\end{array}$ & $\begin{array}{r}-1.79 \\
(1.46)\end{array}$ & $\begin{array}{l}.353 \\
(1.16)\end{array}$ \\
\hline \multicolumn{6}{|l|}{ Quality } \\
\hline Total deficiency count & $\begin{array}{l}0.349 \\
(0.853)\end{array}$ & $\begin{array}{r}-0.498 \\
(3.09)\end{array}$ & $\begin{array}{r}0.591 \\
(1.89)\end{array}$ & $\begin{array}{r}-0.349 \\
(1.68)\end{array}$ & $\begin{array}{l}1.53 \\
(1.36)\end{array}$ \\
\hline 1(severe deficiency) & $\begin{array}{r}-0.058 \\
(0.111)\end{array}$ & $\begin{array}{r}-0.26 \\
(2.86)\end{array}$ & $\begin{array}{r}0.058 \\
(1.63)\end{array}$ & $\begin{array}{l}-1.9 \\
(1.47)\end{array}$ & $\begin{array}{l}.254 \\
(1.16)\end{array}$ \\
\hline Prct. private-pay & $\begin{array}{l}2.47 \\
(3.06)\end{array}$ & $\begin{array}{l}2.53 \\
(4.68)\end{array}$ & $\begin{array}{r}-0.0918 \\
(3.35)\end{array}$ & $\begin{array}{r}-1.58 \\
(2.97)\end{array}$ & $\begin{array}{r}-1.27 \\
(2.63)\end{array}$ \\
\hline \multicolumn{6}{|l|}{ Other strategic margins } \\
\hline Acuity Index & $\begin{array}{r}-0.181 \\
(0.276)\end{array}$ & $\begin{array}{r}-0.201 \\
\quad(2.86)\end{array}$ & $\begin{array}{r}-0.005 \\
(1.64)\end{array}$ & $\begin{array}{r}-2.00 \\
(1.48)\end{array}$ & $\begin{array}{r}-0.006 \\
(1.17)\end{array}$ \\
\hline Number of beds & $\begin{array}{r}-8.63 \\
(26.4)\end{array}$ & $\begin{array}{r}-9.58 \\
(31.8)\end{array}$ & $\begin{array}{r}-6.39 \\
(23.6)\end{array}$ & $\begin{array}{l}1.12 \\
(20.1)\end{array}$ & $\begin{array}{l}.506 \\
(17.2)\end{array}$ \\
\hline Prct. of beds occupied & $\begin{array}{r}.505 \\
(4.7)\end{array}$ & $\begin{array}{r}.63 \\
(5.84)\end{array}$ & $\begin{array}{r}-2.31 \\
(4.32)\end{array}$ & $\begin{array}{r}-1.72 \\
(3.62)\end{array}$ & $\begin{array}{r}.37 \\
(3.37)\end{array}$ \\
\hline \multicolumn{6}{|l|}{ Market characteristics } \\
\hline Market HHI - same county & $\begin{array}{r}0.0125 \\
(.0301)\end{array}$ & $\begin{array}{r}-0.141 \\
(2.82)\end{array}$ & $\begin{array}{r}0.149 \\
(1.6)\end{array}$ & $\begin{array}{r}-1.73 \\
(1.44)\end{array}$ & $\begin{array}{r}0.419 \\
(1.14)\end{array}$ \\
\hline Union density, private only & $\begin{array}{r}-3.94 \\
(3.54)\end{array}$ & $\begin{array}{r}-5.14 \\
(5.15)\end{array}$ & $\begin{array}{r}-3.78 \\
(3.92)\end{array}$ & $\begin{array}{r}-5.27 \\
(3.71)\end{array}$ & $\begin{array}{r}-5.90 \\
(3.20)\end{array}$ \\
\hline \multicolumn{6}{|l|}{ Election characteristics } \\
\hline Log(NLRB election unit size) & $\begin{array}{l}-.184 \\
(0.169)\end{array}$ & $\begin{array}{r}-.367 \\
(2.85)\end{array}$ & $\begin{array}{r}-.0016 \\
(1.62)\end{array}$ & $\begin{array}{r}-1.87 \\
(1.46)\end{array}$ & $\begin{array}{l}.271 \\
(1.16)\end{array}$ \\
\hline $\log$ (Valid votes cast in election) & $\begin{array}{l}-.207 \\
(0.167)\end{array}$ & $\begin{array}{r}-.385 \\
(2.84)\end{array}$ & $\begin{array}{r}-.0114 \\
(1.62)\end{array}$ & $\begin{array}{r}-1.89 \\
(1.45)\end{array}$ & $\begin{array}{l}.248 \\
(1.15)\end{array}$ \\
\hline Number of homes observed & 131 & 350 & 483 & 576 & 626 \\
\hline Number of home-dates observed & 587 & 1,517 & 2,042 & 2,480 & 2,688 \\
\hline Number of home-date-outcomes observed & 6,986 & 18,077 & 24,350 & 29,574 & 32,053 \\
\hline Adjusted $\mathrm{R}^{2}$ & .526 & .604 & .629 & .64 & .646 \\
\hline Joint-null $F$-test $p$-value & .844 & .933 & .977 & .468 & .296 \\
\hline
\end{tabular}

Coefficient (within-home-correlation corrected SE). Significance: $\quad *: 10 \% \quad * *: 5 \% \quad * * *: 1 \%$.

Each column presents discontinuity estimates from a separate system of second-order linear equations (3).

Only observations from homes with vote share within $h$ of the 0.50 threshold are used.

Table A.1: Test for discontinuity in mean nursing homes characteristics in pre-election panel using quadratic vote share function 
Table A.2: Estimated effect on certified nurse's aide (NA) hours per resident day (HPRD) in post-election panel under various bandwidth and specifications

\begin{tabular}{|c|c|c|c|c|c|c|c|c|c|c|c|c|}
\hline \multirow{2}{*}{$\begin{array}{l}\text { Bandwidth }(h) \text { : } \\
\text { Specification: }\end{array}$} & \multicolumn{3}{|c|}{$h=0.05$} & \multicolumn{3}{|c|}{$h=0.15$} & \multicolumn{3}{|c|}{$h=0.25$} & \multicolumn{3}{|c|}{$h=0.35$} \\
\hline & 1 & 2 & 3 & 1 & 2 & 3 & 1 & 2 & 3 & 1 & 2 & 3 \\
\hline$\hat{\tau}$ & $\begin{array}{l}-.198 \\
(.078)^{* *}\end{array}$ & $\begin{array}{c}-.218 \\
(.069)^{* * *}\end{array}$ & $\begin{array}{c}-.209 \\
(.068)^{* * *}\end{array}$ & & nel A: Exp & cted value & not depe & d on vote & & & & \\
\hline$\hat{\tau}$ & & & & $\begin{array}{l}-.228 \\
(.096)^{* *}\end{array}$ & $\begin{array}{c}\text { Panel B } \\
-.257 \\
(.086)^{* * *}\end{array}$ & $\begin{array}{c}\text { Expected } \\
-.243 \\
(.084)^{* * *}\end{array}$ & $\begin{array}{c}\text { linear in } \\
-.138 \\
(.076)^{*}\end{array}$ & $\begin{array}{c}\text { ote share } \\
-.124 \\
(.068)^{*}\end{array}$ & $\begin{array}{l}-.124 \\
(.068)^{*}\end{array}$ & $\begin{array}{l}-.102 \\
(.067)\end{array}$ & $\begin{array}{l}-.094 \\
(.061)\end{array}$ & $\begin{array}{r}-.068 \\
(.06)\end{array}$ \\
\hline$\hat{\tau}$ & & & & $\begin{array}{c}-.392 \\
(.181)^{* *}\end{array}$ & $\begin{array}{c}\text { Panel C } \\
-.477 \\
(.16)^{* * *}\end{array}$ & $\begin{array}{c}\text { Expected } \\
-.470 \\
(.154)^{* * *}\end{array}$ & $\begin{array}{c}\text { square ir } \\
-.298 \\
(.12)^{* *}\end{array}$ & $\begin{array}{c}\text { vote share } \\
-.358 \\
(.107)^{* * *}\end{array}$ & $\begin{array}{c}-.340 \\
(.105)^{* * *}\end{array}$ & $\begin{array}{c}-.248 \\
(.102)^{* *}\end{array}$ & $\begin{array}{l}-.245 \\
(.09)^{* * *}\end{array}$ & $\begin{array}{c}-.254 \\
(.088)^{* * *}\end{array}$ \\
\hline$\hat{\tau}$ & & & & $\begin{array}{l}-.347 \\
(.147)^{* *}\end{array}$ & $\begin{array}{l}\text { Panel D } \\
-.416 \\
(.13)^{* * *}\end{array}$ & $\begin{array}{c}\text { Expected } \\
-.408 \\
(.125)^{* * *}\end{array}$ & $\begin{array}{c}\text { cubic in } \\
-.393 \\
(.202)^{*}\end{array}$ & $\begin{array}{l}\text { ote share } \\
\quad-.506 \\
(.18)^{* * *}\end{array}$ & $\begin{array}{c}-.478 \\
(.176)^{* * *}\end{array}$ & $\begin{array}{c}-.31 \\
(.145)^{* *}\end{array}$ & $\begin{array}{c}-.422 \\
(.129)^{* * *}\end{array}$ & $\begin{array}{c}-.400 \\
(.126)^{* * *}\end{array}$ \\
\hline$\hat{\tau}$ & & & & & Panel E & Expected $\mathrm{v}$ & $\begin{array}{c}\text { quartic i } \\
\quad-.506 \\
(.451)\end{array}$ & $\begin{array}{c}\text { vote share } \\
-.609 \\
(.411)\end{array}$ & $\begin{array}{l}-.659 \\
(.398)^{*}\end{array}$ & $\begin{array}{l}-.498 \\
(.233)^{* *}\end{array}$ & $\begin{array}{c}-.569 \\
(.207)^{* * *}\end{array}$ & $\begin{array}{l}-.513 \\
(.2)^{* *}\end{array}$ \\
\hline Conditional on he & me's pre-el & ction meal & & & & & & & & & & \\
\hline this variable & $\mathrm{N}$ & Y & Y & $\mathrm{N}$ & Y & Y & $\mathrm{N}$ & $\mathrm{Y}$ & $\mathrm{Y}$ & $\mathrm{N}$ & $\mathrm{Y}$ & Y \\
\hline all variables & $\mathrm{N}$ & $\mathrm{N}$ & $\mathrm{Y}$ & $\mathrm{N}$ & $\mathrm{N}$ & $\mathrm{Y}$ & $\mathrm{N}$ & $\mathrm{N}$ & $\mathrm{Y}$ & $\mathrm{N}$ & $\mathrm{N}$ & $\mathrm{Y}$ \\
\hline Homes obs. & 131 & 128 & 126 & 350 & 343 & 340 & 483 & 476 & 473 & 576 & 568 & 564 \\
\hline Home-dates obs. & 1,142 & 1,122 & 1,117 & 3,031 & 2,981 & 2,970 & 4,174 & 4,124 & 4,113 & 4,934 & 4,879 & 4,860 \\
\hline
\end{tabular}


Table A.3: Estimated effect on licensed practical nurses (LPN) hours per resident day (HPRD) in post-election panel under various bandwidth and specifications

\begin{tabular}{|c|c|c|c|c|c|c|c|c|c|c|c|c|}
\hline \multirow{2}{*}{$\begin{array}{l}\text { Bandwidth }(h) \text { : } \\
\text { Specification: }\end{array}$} & \multicolumn{3}{|c|}{$h=0.05$} & \multicolumn{3}{|c|}{$h=0.15$} & \multicolumn{3}{|c|}{$h=0.25$} & \multicolumn{3}{|c|}{$h=0.35$} \\
\hline & 1 & 2 & 3 & 1 & 2 & 3 & 1 & 2 & 3 & 1 & 2 & 3 \\
\hline$\hat{\tau}$ & $\begin{array}{l}-.052 \\
(.066)\end{array}$ & $\begin{array}{l}-.070 \\
(.055)\end{array}$ & $\begin{array}{l}-.087 \\
(.048)^{*}\end{array}$ & Panel & : Expec & value & not dep & ad on & e share & & & \\
\hline$\hat{\tau}$ & & & & $\begin{array}{c} \\
-.093 \\
(.081)\end{array}$ & $\begin{array}{c}\text { anel B: } \\
-.118 \\
(.066)^{*}\end{array}$ & $\begin{array}{c}\text { pected } \\
-.109 \\
.062^{*}\end{array}$ & $\begin{array}{c}\text { linear } \\
-.009 \\
(.063)\end{array}$ & $\begin{array}{c}\text { vote sl } \\
-.044 \\
(.051)\end{array}$ & $\begin{array}{l}\text { re } \\
-0.083 \\
(.049)^{*}\end{array}$ & $\begin{array}{l}-.042 \\
(.061)\end{array}$ & $\begin{array}{c}-.04 \\
(.046)\end{array}$ & $\begin{array}{l}-0.064 \\
(.042)\end{array}$ \\
\hline$\hat{\tau}$ & & & & $\begin{array}{c}{ }^{\mathrm{F}} \\
-.052 \\
(.163)\end{array}$ & $\begin{array}{c}\text { nel C: } \\
\quad-.057 \\
(.134)\end{array}$ & $\begin{array}{l}\text { pected } \\
-0.038 \\
(.112)\end{array}$ & $\begin{array}{c}\text { square } \\
-.091 \\
(.098)\end{array}$ & $\begin{array}{l}\text { vote s } \\
-.115 \\
(.081)\end{array}$ & $\begin{array}{l}\text { re } \\
\quad-0.09 \\
(.074)\end{array}$ & $\begin{array}{l}-.003 \\
(.087)\end{array}$ & $\begin{array}{l}-.062 \\
(.066)\end{array}$ & $\begin{array}{l}-.082 \\
(.061)\end{array}$ \\
\hline$\hat{\tau}$ & & & & $\begin{array}{l}-.063 \\
(.13)\end{array}$ & $\begin{array}{l}\text { nel D: } \\
-.074 \\
(.107)\end{array}$ & $\begin{array}{l}\text { pected } \\
-0.057 \\
(.09)\end{array}$ & $\begin{array}{l}\text { cubic } \mathrm{i} \\
-.196 \\
(.173)\end{array}$ & $\begin{array}{l}\text { vote sl } \\
-.19 \\
(.141)\end{array}$ & $\begin{array}{l}-0.149 \\
(.126)\end{array}$ & $\begin{array}{l}-.173 \\
(.121)\end{array}$ & $\begin{array}{l}-.181 \\
(.099)^{*}\end{array}$ & $\begin{array}{r}-0.138 \\
(.088)\end{array}$ \\
\hline$\hat{\tau}$ & & & & & nel E: E & ected $v$ & $\begin{array}{c}\text { quartic } \\
.34 \\
(.398)\end{array}$ & $\begin{array}{l}\text { vote } \mathrm{s} \\
.333 \\
(.322)\end{array}$ & $\begin{array}{l}.235 \\
(.275)\end{array}$ & $\begin{array}{l}-.18 \\
(.204)\end{array}$ & $\begin{array}{l}-.12 \\
(.165)\end{array}$ & $\begin{array}{l}-.042 \\
(.151)\end{array}$ \\
\hline $\begin{array}{l}\text { Conditional on } \mathrm{h} \\
\text { this variable } \\
\text { all variables }\end{array}$ & $\begin{array}{l}\text { ne's pre } \\
\text { N } \\
\text { N }\end{array}$ & $\begin{array}{l}\text { lection } \\
\text { Y } \\
\text { N }\end{array}$ & $\begin{array}{l}\text { ean of: } \\
\text { Y } \\
\text { Y }\end{array}$ & $\begin{array}{l}\mathrm{N} \\
\mathrm{N}\end{array}$ & $\begin{array}{l}\mathrm{Y} \\
\mathrm{N}\end{array}$ & $\begin{array}{l}\mathrm{Y} \\
\mathrm{Y}\end{array}$ & $\begin{array}{l}\mathrm{N} \\
\mathrm{N}\end{array}$ & $\begin{array}{l}\mathrm{Y} \\
\mathrm{N}\end{array}$ & $\begin{array}{l}\mathrm{Y} \\
\mathrm{Y}\end{array}$ & $\begin{array}{l}\mathrm{N} \\
\mathrm{N}\end{array}$ & $\begin{array}{l}\mathrm{Y} \\
\mathrm{N}\end{array}$ & $\begin{array}{l}\mathrm{Y} \\
\mathrm{Y}\end{array}$ \\
\hline $\begin{array}{l}\text { Homes obs. } \\
\text { Home-dates obs. }\end{array}$ & $\begin{array}{c}131 \\
1,147\end{array}$ & $\begin{array}{c}129 \\
1,128\end{array}$ & $\begin{array}{c}126 \\
1,122\end{array}$ & $\begin{array}{c}350 \\
3,038\end{array}$ & $\begin{array}{c}348 \\
3,019\end{array}$ & $\begin{array}{c}340 \\
2,976\end{array}$ & $\begin{array}{c}483 \\
4,187\end{array}$ & $\begin{array}{c}481 \\
4,168\end{array}$ & $\begin{array}{c}473 \\
4,125\end{array}$ & $\begin{array}{c}576 \\
4,948\end{array}$ & $\begin{array}{c}572 \\
4,916\end{array}$ & $\begin{array}{c}564 \\
4,873\end{array}$ \\
\hline
\end{tabular}

Coefficient. Within-site-correlation corrected SE. Significance: $\quad *: 10 \% \quad * *: 5 \% \quad * * *: 1 \%$. Only observations from homes with vote share within $h$ of the 0.50 threshold are used. Panels vary the assumed form of the outcome's expected value function, varying assumptions on $f_{0}$ and $f_{1}$ in $E\left[y_{i t} \mid X_{i}, D_{i}\right]=\tau D_{i}+f_{1}\left(X_{i}\right) D_{i}+\beta_{0}+f_{0}\left(X_{i}\right)$. For each bandwidth and functional form, estimates of the discontinuity parameter from each of 3 specifications are presented. 
Table A.4: Estimated effect on registered nurse (RN) hours per resident day (HPRD) in post-election panel under various bandwidth and specifications

\begin{tabular}{|c|c|c|c|c|c|c|c|c|c|c|c|c|}
\hline \multirow{2}{*}{$\begin{array}{l}\text { Bandwidth }(h): \\
\text { Specification: }\end{array}$} & \multicolumn{3}{|c|}{$h=0.05$} & \multicolumn{3}{|c|}{$h=0.15$} & \multicolumn{3}{|c|}{$h=0.25$} & \multicolumn{3}{|c|}{$h=0.35$} \\
\hline & 1 & 2 & 3 & 1 & 2 & 3 & 1 & 2 & 3 & 1 & 2 & 3 \\
\hline$\hat{\tau}$ & $\begin{array}{l}-.148 \\
(.137)\end{array}$ & $\begin{array}{l}-.248 \\
(.116)^{* *}\end{array}$ & $\begin{array}{l}-0.233 \\
(.095)^{* *}\end{array}$ & & Panel A: & spected va & bes not de & end on vot & share & & & \\
\hline$\hat{\tau}$ & & & & $\begin{array}{l}-.186 \\
(.161)\end{array}$ & $\begin{array}{c}\text { Pan } \\
-.34 \\
(.134)^{* *}\end{array}$ & $\begin{array}{c}\text { B: Expect } \\
-0.327 \\
(.114)^{* * *}\end{array}$ & $\begin{array}{l}\text { lue linear } \\
-.00837 \\
(.119)\end{array}$ & $\begin{array}{l}\text { a vote sha } \\
-.185 \\
(.097)^{*}\end{array}$ & $\begin{array}{c}-0.252 \\
(.089)^{* * *}\end{array}$ & $\begin{array}{l}-.033 \\
(.104)\end{array}$ & $\begin{array}{l}-.151 \\
(.084)^{*}\end{array}$ & $\begin{array}{l}-0.195 \\
(.077)^{* *}\end{array}$ \\
\hline$\hat{\tau}$ & & & & $\begin{array}{c}-.37 \\
(.286)\end{array}$ & $\begin{array}{c}\text { Pane } \\
-.441 \\
(.237)^{*}\end{array}$ & $\begin{array}{c}\text { C: Expect } \\
-.313 \\
(.186)^{*}\end{array}$ & $\begin{array}{c}\text { lue squar } \\
-.196 \\
(.198)\end{array}$ & $\begin{array}{c}\text { n vote sha } \\
-.365 \\
(.17)^{* *}\end{array}$ & $\begin{array}{l}-.310 \\
(.139)^{* *}\end{array}$ & $\begin{array}{l}-.060 \\
(.168)\end{array}$ & $\begin{array}{l}-.271 \\
(.137)^{* *}\end{array}$ & $\begin{array}{c}-.319 \\
(.119)^{* * *}\end{array}$ \\
\hline$\hat{\tau}$ & & & & $\begin{array}{l}-.319 \\
(.242)\end{array}$ & $\begin{array}{c}\text { Pan } \\
-.412 \\
(.204)^{* *}\end{array}$ & $\begin{array}{c}\text { D: Expect } \\
-0.316 \\
(.159)^{* *}\end{array}$ & $\begin{array}{l}\text { lue cubic } \\
-.708 \\
(.326)^{* *}\end{array}$ & $\begin{array}{l}\text { vote shar } \\
-.716 \\
(.267)^{* * *}\end{array}$ & $\begin{array}{l}-0.561 \\
(.203)^{* * *}\end{array}$ & $\begin{array}{l}-.334 \\
(.233)\end{array}$ & $\begin{array}{c}-.475 \\
(.202)^{* *}\end{array}$ & $\begin{array}{c}-0.371 \\
(.163)^{* *}\end{array}$ \\
\hline$\hat{\tau}$ & & & & & Pane & E: Expecte & $\begin{array}{c}\text { ue quarti } \\
.164 \\
(.642)\end{array}$ & $\begin{array}{c}\text { In vote sha } \\
.067 \\
(.458)\end{array}$ & $\begin{array}{l}.170 \\
(.408)\end{array}$ & $\begin{array}{l}-.835 \\
(.358)^{* *}\end{array}$ & $\begin{array}{c}-.738 \\
(.295)^{* *}\end{array}$ & $\begin{array}{c}-0.579 \\
(.232)^{* *}\end{array}$ \\
\hline $\begin{array}{l}\text { Conditional on } \mathrm{h} \\
\text { this variable } \\
\text { all variables }\end{array}$ & $\begin{array}{l}\text { me's pre } \\
\text { N } \\
\mathrm{N}\end{array}$ & $\begin{array}{c}\text { lection } \mathrm{m} \\
\mathrm{Y} \\
\mathrm{N}\end{array}$ & $\begin{array}{r}\text { n of: } \\
\text { Y } \\
Y\end{array}$ & $\begin{array}{l}\mathrm{N} \\
\mathrm{N}\end{array}$ & $\begin{array}{l}\mathrm{Y} \\
\mathrm{N}\end{array}$ & $\begin{array}{l}\mathrm{Y} \\
\mathrm{Y}\end{array}$ & $\begin{array}{l}\mathrm{N} \\
\mathrm{N}\end{array}$ & $\begin{array}{l}\mathrm{Y} \\
\mathrm{N}\end{array}$ & $\begin{array}{l}\mathrm{Y} \\
\mathrm{Y}\end{array}$ & $\begin{array}{l}\mathrm{N} \\
\mathrm{N}\end{array}$ & $\begin{array}{l}\mathrm{Y} \\
\mathrm{N}\end{array}$ & $\begin{array}{l}\mathrm{Y} \\
\mathrm{Y}\end{array}$ \\
\hline $\begin{array}{l}\text { Homes obs. } \\
\text { Home-dates obs. }\end{array}$ & $\begin{array}{c}131 \\
1,146\end{array}$ & $\begin{array}{c}128 \\
1,133\end{array}$ & $\begin{array}{c}126 \\
1,123\end{array}$ & $\begin{array}{c}350 \\
3,036\end{array}$ & $\begin{array}{c}344 \\
3,007\end{array}$ & $\begin{array}{c}340 \\
2,978\end{array}$ & $\begin{array}{c}483 \\
4,186\end{array}$ & $\begin{array}{c}477 \\
4,157\end{array}$ & $\begin{array}{c}473 \\
4,128\end{array}$ & $\begin{array}{c}576 \\
4,947\end{array}$ & $\begin{array}{c}568 \\
4,905\end{array}$ & $\begin{array}{c}564 \\
4,876 \\
\end{array}$ \\
\hline
\end{tabular}

each bandwidth and functional form, estimates of the discontinuity parameter from each of 3 specifications are presented. 
Table A.5: Estimated effect on total deficiency count in post-election panel under various bandwidth and specifications

\begin{tabular}{|c|c|c|c|c|c|c|c|c|c|c|c|c|}
\hline \multirow{2}{*}{$\begin{array}{l}\text { Bandwidth }(h) \text { : } \\
\text { Specification: }\end{array}$} & \multicolumn{3}{|c|}{$h=0.05$} & \multicolumn{3}{|c|}{$h=0.15$} & \multicolumn{3}{|c|}{$h=0.25$} & \multicolumn{3}{|c|}{$h=0.35$} \\
\hline & 1 & 2 & 3 & 1 & 2 & 3 & 1 & 2 & 3 & 1 & 2 & 3 \\
\hline$\hat{\tau}$ & $\begin{array}{l}1.041 \\
(.576)^{*}\end{array}$ & $\begin{array}{l}.895 \\
(.549)\end{array}$ & $\begin{array}{c}1.274 \\
(.513)^{* *}\end{array}$ & & anel A: & xpected v & does not de & end on $v$ & e share & & & \\
\hline$\hat{\tau}$ & & & & $\begin{array}{l}.757 \\
(.726)\end{array}$ & $\begin{array}{l}\text { Pan } \\
.759 \\
(.712)\end{array}$ & $\begin{array}{l}\text { B: Expec } \\
1.225 \\
(.653)^{*}\end{array}$ & $\begin{array}{l}\text { ralue linear } \\
\quad .677 \\
(.569)\end{array}$ & $\begin{array}{l}\text { vote sh } \\
.562 \\
(.556)\end{array}$ & $\begin{array}{l}0.911 \\
(.516)^{*}\end{array}$ & $\begin{array}{l}1.152 \\
(.507)^{* *}\end{array}$ & $\begin{array}{c}.92 \\
(.492)^{*}\end{array}$ & $\begin{array}{l}1.165 \\
(.46)^{* *}\end{array}$ \\
\hline$\hat{\tau}$ & & & & $\begin{array}{c}1.886 \\
(1.376)\end{array}$ & $\begin{array}{c}\text { Pan } \\
.569 \\
(1.312)\end{array}$ & $\begin{array}{c}\text { C: Expec } \\
1.962 \\
(1.294)\end{array}$ & $\begin{array}{c}\text { alue square } \\
.454 \\
(.893)\end{array}$ & $\begin{array}{l}\mathrm{n} \text { vote } \mathrm{sh} \\
.495 \\
(.879)\end{array}$ & $\begin{array}{l}1.06 \\
(.813)\end{array}$ & $\begin{array}{c}.277 \\
(.731)\end{array}$ & $\begin{array}{c}.349 \\
(.731)\end{array}$ & $\begin{array}{l}1.006 \\
(.681)\end{array}$ \\
\hline$\hat{\tau}$ & & & & $\begin{array}{c}1.575 \\
(1.106)\end{array}$ & $\begin{array}{l}\text { Pan } \\
.621 \\
(1.062)\end{array}$ & $\begin{array}{c}\text { D: Expec } \\
1.768 \\
(1.034)^{*}\end{array}$ & $\begin{array}{l}\text { value cubic } \\
3.213 \\
(1.442)^{* *}\end{array}$ & $\begin{array}{l}\text { vote sh } \\
1.753 \\
(1.363)\end{array}$ & $\begin{array}{l}\mathrm{e} \\
3.349 \\
(1.343)^{* *}\end{array}$ & $\begin{array}{c}.89 \\
(1.105)\end{array}$ & $\begin{array}{c}.646 \\
(1.064)\end{array}$ & $\begin{array}{c}1.503 \\
(1.014)\end{array}$ \\
\hline$\hat{\tau}$ & & & & & Pane & E: Expect & $\begin{array}{l}\text { alue quartic } \\
.991 \\
(3.534)\end{array}$ & $\begin{array}{l}n \text { vote s } \\
-1.73 \\
(3.199)\end{array}$ & $\begin{array}{l}\text { re } \\
0.238 \\
(3.153)\end{array}$ & $\begin{array}{c}3.88 \\
(1.769)^{* *}\end{array}$ & $\begin{array}{l}2.428 \\
(1.71)\end{array}$ & $\begin{array}{c}4.495 \\
(1.666)^{* * *}\end{array}$ \\
\hline $\begin{array}{l}\text { Conditional on ho } \\
\text { this variable } \\
\text { all variables }\end{array}$ & $\begin{array}{l}\text { ne's pre- } \\
\text { N } \\
\text { N }\end{array}$ & $\begin{array}{c}\text { ection } n \\
\text { Y } \\
\mathrm{N}\end{array}$ & $\begin{array}{r}\operatorname{ean} \text { of: } \\
\text { Y } \\
\text { Y }\end{array}$ & $\begin{array}{l}\mathrm{N} \\
\mathrm{N}\end{array}$ & $\begin{array}{l}\mathrm{Y} \\
\mathrm{N}\end{array}$ & $\begin{array}{l}\mathrm{Y} \\
\mathrm{Y}\end{array}$ & $\begin{array}{l}\mathrm{N} \\
\mathrm{N}\end{array}$ & $\begin{array}{l}\mathrm{Y} \\
\mathrm{N}\end{array}$ & $\begin{array}{l}\text { Y } \\
Y\end{array}$ & $\begin{array}{l}\mathrm{N} \\
\mathrm{N}\end{array}$ & $\begin{array}{l}\mathrm{Y} \\
\mathrm{N}\end{array}$ & $\begin{array}{l}\mathrm{Y} \\
\mathrm{Y}\end{array}$ \\
\hline $\begin{array}{l}\text { Homes obs. } \\
\text { Home-dates obs. }\end{array}$ & $\begin{array}{c}132 \\
1,151\end{array}$ & $\begin{array}{c}132 \\
1,151 \\
\end{array}$ & $\begin{array}{c}126 \\
1,125\end{array}$ & $\begin{array}{c}351 \\
3,045\end{array}$ & $\begin{array}{c}351 \\
3,045\end{array}$ & $\begin{array}{c}340 \\
2,981\end{array}$ & $\begin{array}{c}484 \\
4,198 \\
\end{array}$ & $\begin{array}{c}484 \\
4,198 \\
\end{array}$ & $\begin{array}{c}473 \\
4,134 \\
\end{array}$ & $\begin{array}{c}577 \\
4,967 \\
\end{array}$ & $\begin{array}{c}577 \\
4,967 \\
\end{array}$ & $\begin{array}{c}564 \\
4,884 \\
\end{array}$ \\
\hline
\end{tabular}

are used. Panels vary the assumed form of the outcome's expected value function, varying assumptions on $f_{0}$ and $f_{1}$ in $E\left[y_{i t} \mid X_{i}, D_{i}\right]=\tau D_{i}+f_{1}\left(X_{i}\right) D_{i}+\beta_{0}+f_{0}\left(X_{i}\right)$. For each bandwidth and functional form, estimates of the discontinuity parameter from each of 3 specifications are presented. 
Table A.6: Estimated effect on severe deficiency indicator in post-election panel under various bandwidth and specifications

\begin{tabular}{|c|c|c|c|c|c|c|c|c|c|c|c|c|}
\hline \multirow{2}{*}{$\begin{array}{l}\text { Bandwidth }(h) \text { : } \\
\text { Specification: }\end{array}$} & \multicolumn{3}{|c|}{$h=0.05$} & \multicolumn{3}{|c|}{$h=0.15$} & \multicolumn{3}{|c|}{$h=0.25$} & \multicolumn{3}{|c|}{$h=0.35$} \\
\hline & 1 & 2 & 3 & 1 & 2 & 3 & 1 & 2 & 3 & 1 & 2 & 3 \\
\hline$\hat{\tau}$ & $\begin{array}{l}-.038 \\
(.031)\end{array}$ & $\begin{array}{l}-.039 \\
(.031)\end{array}$ & $\begin{array}{l}-0.03 \\
(.027)\end{array}$ & & el A: E & ected v & does not & epend or & vote shai & & & \\
\hline$\hat{\tau}$ & & & & $\begin{array}{l}-.064 \\
(.039)^{*}\end{array}$ & $\begin{array}{l}\text { Panel } \\
-.061 \\
(.039)\end{array}$ & $\begin{array}{r}\text { Expec } \\
-0.039 \\
(.035)\end{array}$ & $\begin{array}{c}\text { value line } \\
-.058 \\
(.032)^{*}\end{array}$ & $\begin{array}{c}\mathrm{r} \text { in vote } \\
-.057 \\
(.032)^{*}\end{array}$ & $\begin{array}{l}\text { hare } \\
\quad-.037 \\
\quad(.03)\end{array}$ & $\begin{array}{l}.003 \\
(.028)\end{array}$ & $\begin{array}{l}.004 \\
(.028)\end{array}$ & $\begin{array}{c}.017 \\
(.026)\end{array}$ \\
\hline$\hat{\tau}$ & & & & $\begin{array}{l}-.038 \\
(.076)\end{array}$ & $\begin{array}{c}\text { Panel } \\
-.03 \\
(.077)\end{array}$ & $\begin{array}{l}\text { Expec } \\
-0.016 \\
(.072)\end{array}$ & $\begin{array}{c}\text { alue squ } \\
-.081 \\
(.048)^{*}\end{array}$ & $\begin{array}{c}\text { e in vote } \\
-.076 \\
(.048)\end{array}$ & $\begin{array}{l}\text { hare } \\
-0.051 \\
(.044)\end{array}$ & $\begin{array}{l}-.116 \\
(.04)^{* * *}\end{array}$ & $\begin{array}{c}-.113 \\
(.041)^{* * *}\end{array}$ & $\begin{array}{l}-0.085 \\
(.037)^{* *}\end{array}$ \\
\hline$\hat{\tau}$ & & & & $\begin{array}{l}-.046 \\
(.06)\end{array}$ & $\begin{array}{l}\text { Panel } \\
-.039 \\
(.061)\end{array}$ & $\begin{array}{l}\text { : Expe } \\
-.022 \\
(.056)\end{array}$ & $\begin{array}{c}\text { value cu } \\
.0008 \\
(.082)\end{array}$ & $\begin{array}{c}c \text { in vote } \\
.015 \\
(.083)\end{array}$ & $\begin{array}{l}\text { hare } \\
.032 \\
(.078)\end{array}$ & $\begin{array}{l}-.054 \\
(.059)\end{array}$ & $\begin{array}{l}-.05 \\
(.059)\end{array}$ & $\begin{array}{l}-0.018 \\
(.054)\end{array}$ \\
\hline$\hat{\tau}$ & & & & & Panel & Expec & $\begin{array}{c}\text { alue qua } \\
-.071 \\
(.196)\end{array}$ & $\begin{array}{c}\text { ic in vot } \\
-.066 \\
(.195)\end{array}$ & $\begin{array}{l}\text { share } \\
-0.038 \\
(.189)\end{array}$ & $\begin{array}{l}.037 \\
(.098)\end{array}$ & $\begin{array}{l}.051 \\
(.099)\end{array}$ & $\begin{array}{l}.055 \\
(.094)\end{array}$ \\
\hline $\begin{array}{l}\text { Conditional on } \mathrm{h} \\
\text { this variable }\end{array}$ & $\begin{array}{l}\text { ne's pre } \\
\mathrm{N}\end{array}$ & lection & $\begin{array}{c}\text { hean of: } \\
\text { Y }\end{array}$ & $\mathrm{N}$ & Y & Y & $\mathrm{N}$ & Y & Y & $\mathrm{N}$ & Y & Y \\
\hline all variables & $\mathrm{N}$ & $\mathrm{N}$ & Y & $\mathrm{N}$ & $\mathrm{N}$ & $\mathrm{Y}$ & $\mathrm{N}$ & $\mathrm{N}$ & $\mathrm{Y}$ & $\mathrm{N}$ & $\mathrm{N}$ & $\mathrm{Y}$ \\
\hline $\begin{array}{l}\text { Homes obs. } \\
\text { Home-dates obs. }\end{array}$ & $\begin{array}{c}132 \\
1,151\end{array}$ & $\begin{array}{c}132 \\
1,151\end{array}$ & $\begin{array}{c}126 \\
1,125\end{array}$ & $\begin{array}{c}351 \\
3,045\end{array}$ & $\begin{array}{c}351 \\
3,045\end{array}$ & $\begin{array}{c}340 \\
2,981\end{array}$ & $\begin{array}{c}484 \\
4,198\end{array}$ & $\begin{array}{c}484 \\
4,198\end{array}$ & $\begin{array}{c}473 \\
4,134\end{array}$ & $\begin{array}{c}577 \\
4,967\end{array}$ & $\begin{array}{c}577 \\
4,967\end{array}$ & $\begin{array}{c}564 \\
4,884\end{array}$ \\
\hline
\end{tabular}

Coefficient. Within-site-correlation corrected SE. Significance: $\quad *: 10 \% \quad * *: 5 \% \quad * * *: 1 \%$. Only observations from homes with vote share within $h$ of the 0.50 threshold are used. Panels vary the assumed form of the outcome's expected value function, varying assumptions on $f_{0}$ and $f_{1}$ in $E\left[y_{i t} \mid X_{i}, D_{i}\right]=\tau D_{i}+f_{1}\left(X_{i}\right) D_{i}+\beta_{0}+f_{0}\left(X_{i}\right)$. For each bandwidth and functional form, estimates of the discontinuity parameter from each of 3 specifications are presented. 
Table A.7: Estimated effect on percentage of residents private-pay in post-election panel under various bandwidth and specifications

\begin{tabular}{|c|c|c|c|c|c|c|c|c|c|c|c|c|}
\hline \multirow{2}{*}{$\begin{array}{l}\text { Bandwidth }(h) \text { : } \\
\text { Specification: }\end{array}$} & \multicolumn{3}{|c|}{$\bar{~} h=0.05$} & \multicolumn{3}{|c|}{$\bar{~} h=0.15$} & \multicolumn{3}{|c|}{$h=0.25$} & \multicolumn{3}{|c|}{$h=0.35$} \\
\hline & 1 & 2 & 3 & 1 & 2 & 3 & 1 & 2 & 3 & 1 & 2 & 3 \\
\hline$\hat{\tau}$ & $\begin{array}{l}-1.385 \\
(2.197)\end{array}$ & $\begin{array}{l}-2.491 \\
(1.47)^{*}\end{array}$ & $\begin{array}{c}-2.468 \\
(1.324)^{*}\end{array}$ & & anel A: E & pected valu & es not depe & d on vote & hare & & & \\
\hline$\hat{\tau}$ & & & & $\begin{array}{l}-3.404 \\
(2.764)\end{array}$ & $\begin{array}{c}\text { Panel } \\
-4.764 \\
(1.92)^{* *}\end{array}$ & $\begin{array}{c}\text { 3: Expecte } \\
-5.197 \\
(1.77)^{* * *}\end{array}$ & $\begin{array}{l}\text { ue linear ir } \\
-2.93 \\
(2.359)\end{array}$ & $\begin{array}{c}\text { ote share } \\
-3.19 \\
(1.63)^{*}\end{array}$ & $\begin{array}{c}-2.887 \\
(1.425)^{* *}\end{array}$ & $\begin{array}{r}-2.457 \\
(1.92)\end{array}$ & $\begin{array}{c}-2.406 \\
(1.418)^{*}\end{array}$ & $\begin{array}{l}-1.993 \\
(1.226)\end{array}$ \\
\hline$\hat{\tau}$ & & & & $\begin{array}{c}8.556 \\
(5.243)\end{array}$ & $\begin{array}{l}\text { Panel } \\
2.679 \\
(3.564)\end{array}$ & $\begin{array}{l}\text { Expectec } \\
1.018 \\
(3.196)\end{array}$ & $\begin{array}{l}\text { e square i } \\
-2.522 \\
(3.566)\end{array}$ & $\begin{array}{c}\text { vote shar } \\
-5.139 \\
2.507^{* *}\end{array}$ & $\begin{array}{l}-5.553 \\
2.212^{* *}\end{array}$ & $\begin{array}{l}-2.958 \\
(2.897)\end{array}$ & $\begin{array}{c}-3.976 \\
(2.083)^{*}\end{array}$ & $\begin{array}{c}-4.178 \\
(1.79)^{* *}\end{array}$ \\
\hline$\hat{\tau}$ & & & & $\begin{array}{c}5.226 \\
(4.217)\end{array}$ & $\begin{array}{c}\text { Pane } \\
.636 \\
(2.877)\end{array}$ & $\begin{array}{l}\text { D: Expecte } \\
-0.674 \\
(2.543)\end{array}$ & $\begin{array}{l}\text { ue cubic ir } \\
8.005 \\
(5.92)\end{array}$ & $\begin{array}{c}\text { ote share } \\
.657 \\
(4.006)\end{array}$ & $\begin{array}{l}-2.105 \\
(3.603)\end{array}$ & $\begin{array}{c}-.801 \\
(4.313)\end{array}$ & $\begin{array}{c}-5.128 \\
(3.055)^{*}\end{array}$ & $\begin{array}{c}-6.682 \\
(2.703)^{* *}\end{array}$ \\
\hline$\hat{\tau}$ & & & & & Panel & : Expected & $\begin{array}{c}\text { e quartic i } \\
26.346 \\
(13.836)^{*}\end{array}$ & $\begin{array}{c}\text { vote shar } \\
14.9 \\
(9.238)\end{array}$ & $\begin{array}{c}13.809 \\
(8.91)\end{array}$ & $\begin{array}{l}10.464 \\
(6.724)\end{array}$ & $\begin{array}{c}3.74 \\
(4.559)\end{array}$ & $\begin{array}{c}-.930 \\
(4.108)\end{array}$ \\
\hline $\begin{array}{l}\text { Conditional on } \mathrm{h} \\
\text { this variable } \\
\text { all variables }\end{array}$ & $\begin{array}{l}\text { ne's pre- } \\
\mathrm{N} \\
\mathrm{N}\end{array}$ & $\begin{array}{c}\text { ection m } \\
\text { Y } \\
\text { N }\end{array}$ & $\begin{array}{r}\text { an of: } \\
\text { Y } \\
\text { Y }\end{array}$ & $\begin{array}{l}\mathrm{N} \\
\mathrm{N}\end{array}$ & $\begin{array}{l}\mathrm{Y} \\
\mathrm{N}\end{array}$ & $\begin{array}{l}\mathrm{Y} \\
\mathrm{Y}\end{array}$ & $\begin{array}{l}\mathrm{N} \\
\mathrm{N}\end{array}$ & $\begin{array}{l}\mathrm{Y} \\
\mathrm{N}\end{array}$ & $\begin{array}{l}\mathrm{Y} \\
\mathrm{Y}\end{array}$ & $\begin{array}{l}\mathrm{N} \\
\mathrm{N}\end{array}$ & $\begin{array}{l}\mathrm{Y} \\
\mathrm{N}\end{array}$ & $\begin{array}{l}\mathrm{Y} \\
\mathrm{Y}\end{array}$ \\
\hline $\begin{array}{l}\text { Homes obs. } \\
\text { Home-dates obs. }\end{array}$ & $\begin{array}{c}132 \\
1,151\end{array}$ & $\begin{array}{c}132 \\
1,151\end{array}$ & $\begin{array}{c}126 \\
1,125\end{array}$ & $\begin{array}{c}351 \\
3,045\end{array}$ & $\begin{array}{c}351 \\
3,045\end{array}$ & $\begin{array}{c}340 \\
2,981\end{array}$ & $\begin{array}{c}484 \\
4,198\end{array}$ & $\begin{array}{c}484 \\
4,198\end{array}$ & $\begin{array}{c}473 \\
4,134\end{array}$ & $\begin{array}{c}577 \\
4,967\end{array}$ & $\begin{array}{c}577 \\
4,967\end{array}$ & $\begin{array}{c}564 \\
4,884\end{array}$ \\
\hline
\end{tabular}

are used. Panels vary the assumed form of the outcome's expected value function, varying assumptions on $f_{0}$ and $f_{1}$ in $E_{i j} y_{i} \mid X_{i}, D_{i}=\tau D_{i}+f_{1}\left(X_{i}\right) D_{i}+\beta_{0}+f_{0}\left(X_{i}\right)$. For each bandwidth and functional form, estimates of the discontinuity parameter from each of 3 specifications are presented. 
Table A.8: Estimated effect on acuity index in post-election panel under various bandwidth and specifications

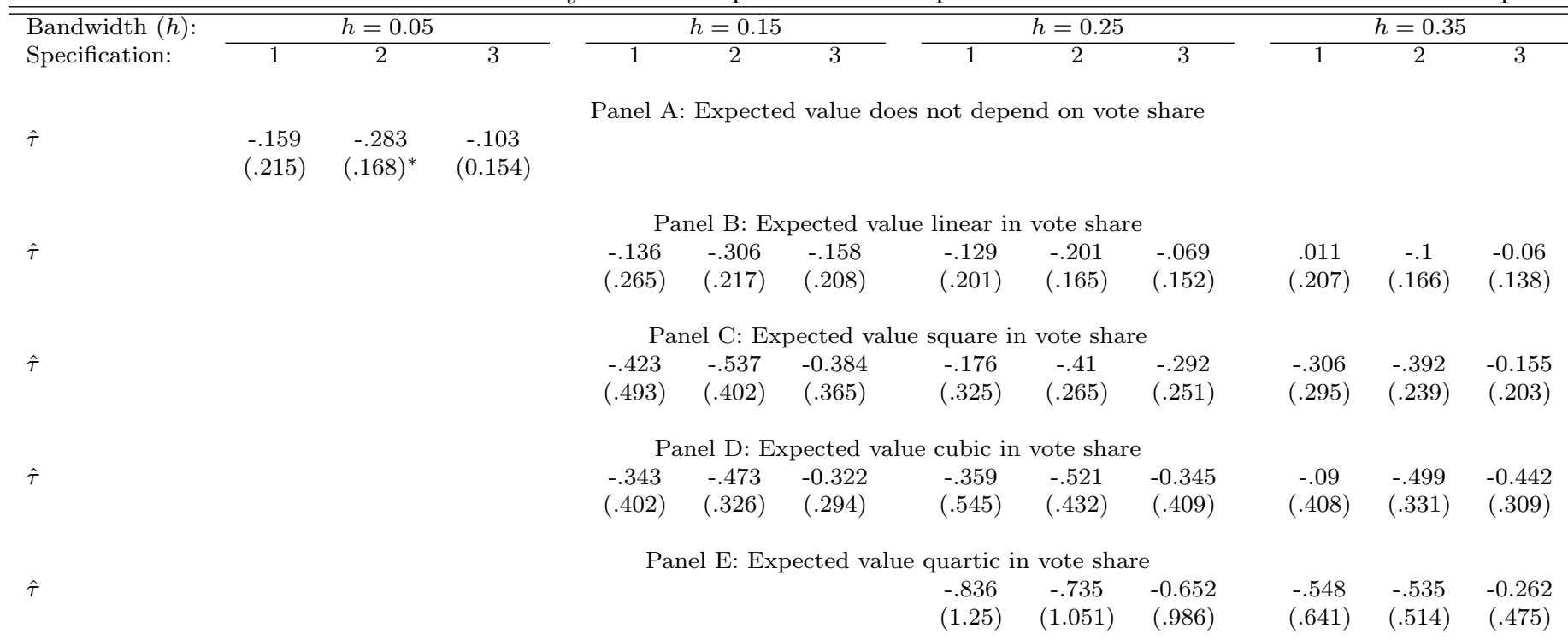

Conditional on home's pre-election mean of:

\begin{tabular}{|c|c|c|c|c|c|c|c|c|c|c|c|c|}
\hline this variable & $\mathrm{N}$ & $\mathrm{Y}$ & $\mathrm{Y}$ & $\mathrm{N}$ & Y & $\mathrm{Y}$ & $\mathrm{N}$ & $\mathrm{Y}$ & $\mathrm{Y}$ & $\mathrm{N}$ & Y & $\mathrm{Y}$ \\
\hline all variables & $\mathrm{N}$ & $\mathrm{N}$ & $\mathrm{Y}$ & $\mathrm{N}$ & $\mathrm{N}$ & $\mathrm{Y}$ & $\mathrm{N}$ & $\mathrm{N}$ & $\mathrm{Y}$ & $\mathrm{N}$ & $\mathrm{N}$ & $\mathrm{Y}$ \\
\hline Homes obs. & 132 & 131 & 126 & 350 & 349 & 339 & 483 & 482 & 472 & 576 & 575 & 563 \\
\hline
\end{tabular}

\begin{tabular}{|c|c|c|c|c|c|c|c|c|c|c|c|c|}
\hline $\begin{array}{l}\text { Homes obs. } \\
\text { Home-dates }\end{array}$ & $\begin{array}{c}132 \\
1,149\end{array}$ & $\begin{array}{c}131 \\
1,148\end{array}$ & $\begin{array}{c}126 \\
1,123\end{array}$ & $\begin{array}{c}350 \\
3,034\end{array}$ & $\begin{array}{c}349 \\
3,033\end{array}$ & $\begin{array}{c}339 \\
2,970\end{array}$ & $\begin{array}{c}483 \\
4,182\end{array}$ & $\begin{array}{c}482 \\
4,181\end{array}$ & $\begin{array}{c}472 \\
4,118\end{array}$ & $\begin{array}{c}576 \\
4,947\end{array}$ & $\begin{array}{c}575 \\
4,946\end{array}$ & 563 \\
\hline Hor & 1,149 & 1,148 & 1,123 & 3,034 & 3,033 & 2,970 & 4,182 & 4,181 & 4,118 & 4,947 & 4,946 & 864 \\
\hline
\end{tabular}

Coefficient. Within-site-correlation corrected SE. Significance: $\quad *: 10 \% \quad * *: 5 \% \quad * * *: 1 \%$. Only observations from homes with vote share within $h$ of the 0.50 threshold are used. Panels vary the assumed form of the outcome's expected value function, varying assumptions on $f_{0}$ and $f_{1}$ in $E\left[y_{i t} \mid X_{i}, D_{i}\right]=\tau D_{i}+f_{1}\left(X_{i}\right) D_{i}+\beta_{0}+f_{0}\left(X_{i}\right)$. For each bandwidth and functional form, estimates of the discontinuity parameter from each of 3 specifications are presented. 
Table A.9: Estimated effect on total bed count in post-election panel under various bandwidth and specifications

\begin{tabular}{|c|c|c|c|c|c|c|c|c|c|c|c|c|}
\hline \multirow{2}{*}{$\begin{array}{l}\text { Bandwidth }(h) \text { : } \\
\text { Specification: }\end{array}$} & \multicolumn{3}{|c|}{$h=0.05$} & \multicolumn{3}{|c|}{$h=0.15$} & \multicolumn{3}{|c|}{$h=0.25$} & \multicolumn{3}{|c|}{$h=0.35$} \\
\hline & 1 & 2 & 3 & 1 & 2 & 3 & 1 & 2 & 3 & 1 & 2 & 3 \\
\hline$\hat{\tau}$ & $\begin{array}{c}-9.88 \\
(15.359)\end{array}$ & $\begin{array}{c}4.001 \\
(4.285)\end{array}$ & $\begin{array}{c}5.571 \\
(3.824)\end{array}$ & & el A: Ex] & cted valu & es not dep & ad on vot & share & & & \\
\hline$\hat{\tau}$ & & & & $\begin{array}{c}-8.251 \\
(17.984)\end{array}$ & $\begin{array}{c}\text { Panel I } \\
5.255 \\
(4.594)\end{array}$ & $\begin{array}{c}\text { Expecte } \\
5.721 \\
(4.368)\end{array}$ & $\begin{array}{c}\text { ue linear i } \\
\quad-.213 \\
(14.274)\end{array}$ & $\begin{array}{c}\text { vote shar } \\
1.596 \\
(3.275)\end{array}$ & $\begin{array}{c}2.248 \\
(3.147)\end{array}$ & $\begin{array}{c}3.504 \\
(11.947)\end{array}$ & $\begin{array}{c}1.306 \\
(2.642)\end{array}$ & $\begin{array}{l}1.438 \\
(2.69)\end{array}$ \\
\hline$\hat{\tau}$ & & & & $\begin{array}{c}-40.1 \\
(34.866)\end{array}$ & $\begin{array}{c}\text { Panel C } \\
4.77 \\
(9.031)\end{array}$ & $\begin{array}{c}\text { Expectec } \\
6.562 \\
(8.338)\end{array}$ & $\begin{array}{c}\text { ue square } \\
-11.18 \\
(21.948)\end{array}$ & $\begin{array}{c}\text { vote sha } \\
3.549 \\
(6.145)\end{array}$ & $\begin{array}{c}4.154 \\
(6.018)\end{array}$ & $\begin{array}{c}-8.41 \\
(18.565)\end{array}$ & $\begin{array}{c}2.45 \\
(5.096)\end{array}$ & $\begin{array}{c}3.612 \\
(4.897)\end{array}$ \\
\hline$\hat{\tau}$ & & & & $\begin{array}{c}-31.3 \\
(28.688)\end{array}$ & $\begin{array}{c}\text { Panel l } \\
4.91 \\
(7.53)\end{array}$ & $\begin{array}{c}\text { Expecte } \\
6.339 \\
(7.023)\end{array}$ & $\begin{array}{c}\text { lue cubic i } \\
-54.989 \\
(36.537)\end{array}$ & $\begin{array}{c}\text { vote shar } \\
11.782 \\
(10.739)\end{array}$ & $\begin{array}{c}15.304 \\
(10.889)\end{array}$ & $\begin{array}{l}-21.493 \\
(26.079)\end{array}$ & $\begin{array}{c}5.438 \\
(6.928)\end{array}$ & $\begin{array}{c}5.679 \\
(6.932)\end{array}$ \\
\hline$\hat{\tau}$ & & & & & Panel E & Expected & $\begin{array}{c}\text { e quartic } \\
-50.208 \\
(71.822)\end{array}$ & $\begin{array}{l}\text { vote sha } \\
-18.236 \\
(22.551)\end{array}$ & $\begin{array}{l}-16.413 \\
(21.211)\end{array}$ & $\begin{array}{l}-54.796 \\
(41.82)\end{array}$ & $\begin{array}{c}12.229 \\
(11.364)\end{array}$ & $\begin{array}{c}16.356 \\
(11.625)\end{array}$ \\
\hline
\end{tabular}

Conditional on home's pre-election mean of: $\begin{array}{llll}\text { this variable } & \mathrm{N} & \mathrm{Y} & \mathrm{Y} \\ \text { all variables } & \mathrm{N} & \mathrm{N} & \mathrm{Y}\end{array}$ all variables $\mathrm{N}$

$\begin{array}{llllllllllll}\text { Homes obs. } & 132 & 132 & 126 & 351 & 351 & 340 & 484 & 484 & 473 & 577 & 577\end{array}$

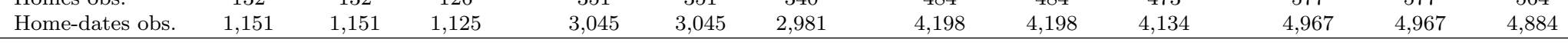

Coefficient. Within-site-correlation corrected SE. Significance: $\quad *: 10 \% \quad * *: 5 \% \quad * * *: 1 \%$. Only observations from homes with vote share within $h$ of the 0.50 threshold are used. Panels vary the assumed form of the outcome's expected value function, varying assumptions on $f_{0}$ and $f_{1}$ in $E\left[y_{i t} \mid X_{i}, D_{i}\right]=\tau D_{i}+f_{1}\left(X_{i}\right) D_{i}+\beta_{0}+f_{0}\left(X_{i}\right)$. For each bandwidth and functional form, estimates of the discontinuity parameter from each of 3 specifications are presented. 
Table A.10: Estimated effect on percentage of beds occupied in post-election panel under various bandwidth and specifications

\begin{tabular}{|c|c|c|c|c|c|c|c|c|c|c|c|c|}
\hline \multirow{2}{*}{$\begin{array}{l}\text { Bandwidth }(h): \\
\text { Specification: }\end{array}$} & \multicolumn{3}{|c|}{$h=0.05$} & \multicolumn{3}{|c|}{$h=0.15$} & \multicolumn{3}{|c|}{$h=0.25$} & \multicolumn{3}{|c|}{$h=0.35$} \\
\hline & 1 & 2 & 3 & 1 & 2 & 3 & 1 & 2 & 3 & 1 & 2 & 3 \\
\hline$\hat{\tau}$ & $\begin{array}{l}1.138 \\
(3.222)\end{array}$ & $\begin{array}{c}1.58 \\
(2.848)\end{array}$ & $\begin{array}{l}1.764 \\
(2.285)\end{array}$ & Pan & A: Exp & ted value & s not dep & d on vote & hare & & & \\
\hline$\hat{\tau}$ & & & & $\begin{array}{l}1.815 \\
(3.774)\end{array}$ & $\begin{array}{c}\text { Panel B } \\
1.825 \\
(3.349)\end{array}$ & $\begin{array}{l}\text { Expected } \\
1.640 \\
(2.708)\end{array}$ & $\begin{array}{c}\text { linear i } \\
-.975 \\
(2.827)\end{array}$ & $\begin{array}{c}\text { vote share } \\
1.364 \\
(2.473)\end{array}$ & $\begin{array}{l}2.475 \\
(2.122)\end{array}$ & $\begin{array}{l}-.396 \\
(2.398)\end{array}$ & $\begin{array}{c}.209 \\
(2.087)\end{array}$ & $\begin{array}{l}1.344 \\
(1.826)\end{array}$ \\
\hline$\hat{\tau}$ & & & & $\begin{array}{l}4.463 \\
(6.83)\end{array}$ & $\begin{array}{c}\text { Panel C } \\
3.774 \\
(6.037)\end{array}$ & $\begin{array}{c}\text { Expected } \\
3.190 \\
(5.034)\end{array}$ & $\begin{array}{c}\text { e square } \\
2.634 \\
(4.63)\end{array}$ & $\begin{array}{c}\text { vote shar } \\
1.729 \\
(4.142)\end{array}$ & $\begin{array}{c}1.382 \\
(3.354)\end{array}$ & $\begin{array}{c}-.54 \\
(3.878)\end{array}$ & $\begin{array}{c}1.659 \\
(3.382)\end{array}$ & $\begin{array}{c}2.219 \\
(2.835)\end{array}$ \\
\hline$\hat{\tau}$ & & & & $\begin{array}{c}3.731 \\
(5.752)\end{array}$ & $\begin{array}{c}\text { Panel D } \\
3.24 \\
(5.122)\end{array}$ & $\begin{array}{c}\text { Expectec } \\
2.768 \\
(4.176)\end{array}$ & $\begin{array}{c}\text { de cubic i } \\
7.828 \\
(7.505)\end{array}$ & $\begin{array}{c}\text { vote share } \\
5.41 \\
(6.554)\end{array}$ & $\begin{array}{c}3.896 \\
(5.547)\end{array}$ & $\begin{array}{c}6.013 \\
(5.429)\end{array}$ & $\begin{array}{c}3.568 \\
(4.886)\end{array}$ & $\begin{array}{c}2.608 \\
(4.041)\end{array}$ \\
\hline$\hat{\tau}$ & & & & & Panel E: & xpected & $\begin{array}{c}\text { quartic } \\
-.441 \\
(14.585)\end{array}$ & $\begin{array}{c}\text { vote shar } \\
3.216 \\
(12.024)\end{array}$ & $\begin{array}{c}5.886 \\
(11.049)\end{array}$ & $\begin{array}{l}7.264 \\
(8.37)\end{array}$ & $\begin{array}{c}3.184 \\
(7.354)\end{array}$ & $\begin{array}{l}1.137 \\
(6.314)\end{array}$ \\
\hline \multicolumn{13}{|c|}{ Conditional on home's pre-election mean of: } \\
\hline $\begin{array}{l}\text { this variable } \\
\text { all variables }\end{array}$ & $\begin{array}{l}\mathrm{N} \\
\mathrm{N}\end{array}$ & $\begin{array}{l}\mathrm{Y} \\
\mathrm{N}\end{array}$ & $\begin{array}{l}\mathrm{Y} \\
\mathrm{Y}\end{array}$ & $\begin{array}{l}\mathrm{N} \\
\mathrm{N}\end{array}$ & $\begin{array}{l}\mathrm{Y} \\
\mathrm{N}\end{array}$ & $\begin{array}{l}\mathrm{Y} \\
\mathrm{Y}\end{array}$ & $\begin{array}{l}\mathrm{N} \\
\mathrm{N}\end{array}$ & $\begin{array}{l}\mathrm{Y} \\
\mathrm{N}\end{array}$ & $\begin{array}{l}\mathrm{Y} \\
\mathrm{Y}\end{array}$ & $\begin{array}{l}\mathrm{N} \\
\mathrm{N}\end{array}$ & $\begin{array}{l}\mathrm{Y} \\
\mathrm{N}\end{array}$ & $\begin{array}{l}\mathrm{Y} \\
\mathrm{Y}\end{array}$ \\
\hline $\begin{array}{l}\text { Homes obs. } \\
\text { Home-dates obs. }\end{array}$ & $\begin{array}{c}132 \\
1,151\end{array}$ & $\begin{array}{c}132 \\
1,151\end{array}$ & $\begin{array}{c}126 \\
1,125\end{array}$ & $\begin{array}{c}351 \\
3,045\end{array}$ & $\begin{array}{c}351 \\
3,045\end{array}$ & $\begin{array}{c}340 \\
2,981\end{array}$ & $\begin{array}{c}484 \\
4,198\end{array}$ & $\begin{array}{c}484 \\
4,198\end{array}$ & $\begin{array}{c}473 \\
4,134\end{array}$ & $\begin{array}{c}577 \\
4,967\end{array}$ & $\begin{array}{c}577 \\
4,967\end{array}$ & $\begin{array}{c}564 \\
4,884\end{array}$ \\
\hline
\end{tabular}

Coefficient. Within-site-correlation corrected SE. Significance: $\quad *: 10 \% \quad * *: 5 \% \quad * * *: 1 \%$. Only observations from homes with vote share within $h$ of the 0.50 threshold are used. Panels vary the assumed form of the outcome's expected value function, varying assumptions on $f_{0}$ and $f_{1}$ in $E\left[y_{i t} \mid X_{i}, D_{i}\right]=\tau D_{i}+f_{1}\left(X_{i}\right) D_{i}+\beta_{0}+f_{0}\left(X_{i}\right)$. For each bandwidth and functional form, estimates of the discontinuity parameter from each of 3 specifications are presented. 
Table A.11: Estimated effect on market concentration (HHI county) in post-election panel under various bandwidth and specifications

\begin{tabular}{|c|c|c|c|c|c|c|c|c|c|c|c|c|}
\hline \multirow{2}{*}{$\begin{array}{l}\text { Bandwidth }(h) \text { : } \\
\text { Specification: }\end{array}$} & \multicolumn{3}{|c|}{$h=0.05$} & \multicolumn{3}{|c|}{$h=0.15$} & \multicolumn{3}{|c|}{$h=0.25$} & \multicolumn{3}{|c|}{$h=0.35$} \\
\hline & 1 & 2 & 3 & 1 & 2 & 3 & 1 & 2 & 3 & 1 & 2 & 3 \\
\hline$\hat{\tau}$ & $\begin{array}{l}.021 \\
(.033)\end{array}$ & $\begin{array}{l}.002 \\
(.005)\end{array}$ & $\begin{array}{l}.004 \\
(.006)\end{array}$ & Panel & Expect & value & not dep & $\mathrm{d}$ on $\mathrm{vc}$ & share & & & \\
\hline$\hat{\tau}$ & & & & $\begin{array}{c}1.022 \\
(.042)\end{array}$ & $\begin{array}{l}\text { nel B: E } \\
.005 \\
(.007)\end{array}$ & $\begin{array}{l}\text { ected v } \\
.005 \\
(.008)\end{array}$ & $\begin{array}{l}\text { linear i } \\
-.008 \\
(.035)\end{array}$ & $\begin{array}{l}\text { vote sh. } \\
.006 \\
(.006)\end{array}$ & $\begin{array}{l}\mathrm{e} \\
.007 \\
(.006)\end{array}$ & $\begin{array}{l}.003 \\
(.031)\end{array}$ & $\begin{array}{c}.005 \\
(.006)\end{array}$ & $\begin{array}{c}.005 \\
(.006)\end{array}$ \\
\hline$\hat{\tau}$ & & & & $\begin{array}{l}{ }^{\mathrm{F}} \\
.079 \\
(.09)\end{array}$ & $\begin{array}{c}\text { nel C: E } \\
-.004 \\
(.016)\end{array}$ & $\begin{array}{c}\text { ected v } \\
-0.001 \\
(.021)\end{array}$ & $\begin{array}{c}\text { square } \\
.051 \\
(.051)\end{array}$ & $\begin{array}{c}\text { vote sh } \\
.008 \\
(.008)\end{array}$ & $\begin{array}{l}.009 \\
(.009)\end{array}$ & $\begin{array}{c}.017 \\
(.045)\end{array}$ & $\begin{array}{c}.008 \\
(.008)\end{array}$ & $\begin{array}{c}.01 \\
(.008)\end{array}$ \\
\hline$\hat{\tau}$ & & & & $\begin{array}{l}.063 \\
(.07)\end{array}$ & $\begin{array}{l}\text { nel D: } \mathrm{E} \\
-.00121 \\
(.012)\end{array}$ & $\begin{array}{l}\text { pected } \\
0.0004 \\
(.016)\end{array}$ & $\begin{array}{l}\text { cubic it } \\
.057 \\
(.102)\end{array}$ & $\begin{array}{l}\text { ote she } \\
-.015 \\
(.016)\end{array}$ & $\begin{array}{l}-.014 \\
(.02)\end{array}$ & $\begin{array}{l}.045 \\
(.061)\end{array}$ & $\begin{array}{c}-.0008 \\
(.01)\end{array}$ & $\begin{array}{l}-.002 \\
(.011)\end{array}$ \\
\hline$\hat{\tau}$ & & & & & el E: Ex & ected ve & $\begin{array}{l}\text { quartic } \\
.15 \\
(.238)\end{array}$ & $\begin{array}{l}\text { vote sh } \\
.001 \\
(.043)\end{array}$ & $\begin{array}{l}.01 \\
(.047)\end{array}$ & $\begin{array}{l}.148 \\
(.12)\end{array}$ & $\begin{array}{l}-.007 \\
(.02)\end{array}$ & $\begin{array}{l}-.002 \\
(.024)\end{array}$ \\
\hline $\begin{array}{l}\text { Conditional on he } \\
\text { this variable }\end{array}$ & ne's pre & lection & $\begin{array}{l}\text { hean of: } \\
\text { Y }\end{array}$ & $\mathrm{N}$ & Y & Y & $\mathrm{N}$ & Y & Y & $\mathrm{N}$ & Y & Y \\
\hline all variables & $\mathrm{N}$ & $\mathrm{N}$ & Y & $\mathrm{N}$ & $\mathrm{N}$ & Y & $\mathrm{N}$ & $\mathrm{N}$ & Y & $\mathrm{N}$ & $\mathrm{N}$ & Y \\
\hline $\begin{array}{l}\text { Homes obs. } \\
\text { Home-dates obs. }\end{array}$ & $\begin{array}{c}132 \\
1,151\end{array}$ & $\begin{array}{c}132 \\
1,151\end{array}$ & $\begin{array}{c}126 \\
1,125\end{array}$ & $\begin{array}{c}351 \\
3,045\end{array}$ & $\begin{array}{c}351 \\
3,045\end{array}$ & $\begin{array}{c}340 \\
2,981\end{array}$ & $\begin{array}{c}484 \\
4,198\end{array}$ & $\begin{array}{c}484 \\
4,198\end{array}$ & $\begin{array}{c}473 \\
4,134\end{array}$ & $\begin{array}{c}577 \\
4,967\end{array}$ & $\begin{array}{c}577 \\
4,967\end{array}$ & $\begin{array}{c}564 \\
4,884\end{array}$ \\
\hline
\end{tabular}

Coefficient. Within-site-correlation corrected SE. Significance: $\quad *: 10 \% \quad * *: 5 \% \quad * * *: 1 \%$. Only observations from homes with vote share within $h$ of the 0.50 threshold are used. Panels vary the assumed form of the outcome's expected value function, varying assumptions on $f_{0}$ and $f_{1}$ in $E\left[y_{i t} \mid X_{i}, D_{i}\right]=\tau D_{i}+f_{1}\left(X_{i}\right) D_{i}+\beta_{0}+f_{0}\left(X_{i}\right)$. For each bandwidth and functional form, estimates of the discontinuity parameter from each of 3 specifications are presented. 
Table A.12: Estimated effect on union density (county) in post-election panel under various bandwidth and specifications

\begin{tabular}{|c|c|c|c|c|c|c|c|c|c|c|c|c|}
\hline \multirow{2}{*}{$\begin{array}{l}\text { Bandwidth }(h): \\
\text { Specification: }\end{array}$} & \multicolumn{3}{|c|}{$h=0.05$} & \multicolumn{3}{|c|}{$h=0.15$} & \multicolumn{3}{|c|}{$h=0.25$} & \multicolumn{3}{|c|}{$h=0.35$} \\
\hline & 1 & 2 & 3 & 1 & 2 & 3 & 1 & 2 & 3 & 1 & 2 & 3 \\
\hline$\hat{\tau}$ & $\begin{array}{c}9.302 \\
(4.845)^{*}\end{array}$ & $\begin{array}{c}11.298 \\
(3.363)^{* * *}\end{array}$ & $\begin{array}{c}11.337 \\
(2.922)^{* * *}\end{array}$ & & Panel A: & xpected val & es not dep & ad on vote s & are & & & \\
\hline$\hat{\tau}$ & & & & $\begin{array}{c}6.741 \\
(5.865)\end{array}$ & $\begin{array}{c}\text { Pan } \\
9.224 \\
(4.31)^{* *}\end{array}$ & $\begin{array}{c}\text { B: Expecte } \\
9.64 \\
(3.448)^{* * *}\end{array}$ & $\begin{array}{c}\text { ue linear i } \\
10.643 \\
(4.58)^{* *}\end{array}$ & $\begin{array}{c}\text { vote share } \\
11.21 \\
(3.458)^{* * *}\end{array}$ & $\begin{array}{c}12.45 \\
(2.896)^{* * *}\end{array}$ & $\begin{array}{c}11.403 \\
(4.007)^{* * *}\end{array}$ & $\begin{array}{c}12.46 \\
(2.936)^{* * *}\end{array}$ & $\begin{array}{c}12.693 \\
(2.506)^{* * *}\end{array}$ \\
\hline$\hat{\tau}$ & & & & $\begin{array}{c}4.376 \\
(11.128)\end{array}$ & $\begin{array}{c}\text { Pane } \\
9.338 \\
(8.476)\end{array}$ & $\begin{array}{c}\text { C: Expecte } \\
6.112 \\
(7.186)\end{array}$ & $\begin{array}{l}\text { ue square } \\
\quad 4.312 \\
(7.23)\end{array}$ & $\begin{array}{c}\text { vote share } \\
9.111 \\
(5.287)^{*}\end{array}$ & $\begin{array}{l}8.005 \\
(4.4)^{*}\end{array}$ & $\begin{array}{c}8.912 \\
(6.112)\end{array}$ & $\begin{array}{c}10.055 \\
(4.411)^{* *}\end{array}$ & $\begin{array}{c}10.854 \\
(3.757)^{* * *}\end{array}$ \\
\hline$\hat{\tau}$ & & & & $\begin{array}{l}5.025 \\
(9.09)\end{array}$ & $\begin{array}{c}\text { Pan } \\
9.306 \\
(6.789)\end{array}$ & $\begin{array}{c}\text { D: Expecte } \\
7.086 \\
(5.731)\end{array}$ & $\begin{array}{c}\text { lue cubic i } \\
3.297 \\
(12.241)\end{array}$ & $\begin{array}{c}\text { vote share } \\
5.725 \\
(8.987)\end{array}$ & $\begin{array}{c}3.445 \\
(7.979)\end{array}$ & $\begin{array}{c}-.915 \\
(8.652)\end{array}$ & $\begin{array}{c}6.408 \\
(6.275)\end{array}$ & $\begin{array}{c}5.367 \\
(5.264)\end{array}$ \\
\hline$\hat{\tau}$ & & & & & Pane & E: Expecte & $\begin{array}{c}\text { quartic } \\
6.254 \\
(26.821)\end{array}$ & $\begin{array}{c}\text { vote share } \\
17.906 \\
(20.749)\end{array}$ & $\begin{array}{c}12.671 \\
(17.445)\end{array}$ & $\begin{array}{c}8.676 \\
(13.985)\end{array}$ & $\begin{array}{c}10.832 \\
(10.231)\end{array}$ & $\begin{array}{c}5.575 \\
(9.128)\end{array}$ \\
\hline $\begin{array}{l}\text { Conditional on } \mathrm{h} \\
\text { this variable } \\
\text { all variables }\end{array}$ & $\begin{array}{c}\text { ne's pre-el } \\
\mathrm{N} \\
\mathrm{N}\end{array}$ & $\begin{array}{c}\text { tion mean } \\
\mathrm{Y} \\
\mathrm{N}\end{array}$ & $\begin{array}{l}\mathrm{Y} \\
\mathrm{Y}\end{array}$ & $\begin{array}{l}\mathrm{N} \\
\mathrm{N}\end{array}$ & $\begin{array}{l}\mathrm{Y} \\
\mathrm{N}\end{array}$ & $\begin{array}{l}\mathrm{Y} \\
\mathrm{Y}\end{array}$ & $\begin{array}{l}\mathrm{N} \\
\mathrm{N}\end{array}$ & $\begin{array}{l}\mathrm{Y} \\
\mathrm{N}\end{array}$ & $\begin{array}{l}\mathrm{Y} \\
\mathrm{Y}\end{array}$ & $\begin{array}{l}\mathrm{N} \\
\mathrm{N}\end{array}$ & $\begin{array}{l}\mathrm{Y} \\
\mathrm{N}\end{array}$ & $\begin{array}{l}\mathrm{Y} \\
\mathrm{Y}\end{array}$ \\
\hline $\begin{array}{l}\text { Homes obs. } \\
\text { Home-dates obs. }\end{array}$ & $\begin{array}{c}132 \\
1,151\end{array}$ & $\begin{array}{c}132 \\
1,151\end{array}$ & $\begin{array}{c}126 \\
1,125\end{array}$ & $\begin{array}{c}351 \\
3,045\end{array}$ & $\begin{array}{c}351 \\
3,045\end{array}$ & $\begin{array}{c}340 \\
2,981\end{array}$ & $\begin{array}{c}484 \\
4,198\end{array}$ & $\begin{array}{c}484 \\
4,198\end{array}$ & $\begin{array}{c}473 \\
4,134\end{array}$ & $\begin{array}{c}577 \\
4,967\end{array}$ & $\begin{array}{c}577 \\
4,967\end{array}$ & $\begin{array}{c}564 \\
4,884\end{array}$ \\
\hline
\end{tabular}
each bandwidth and functional form, estimates of the discontinuity parameter from each of 3 specifications are presented. 


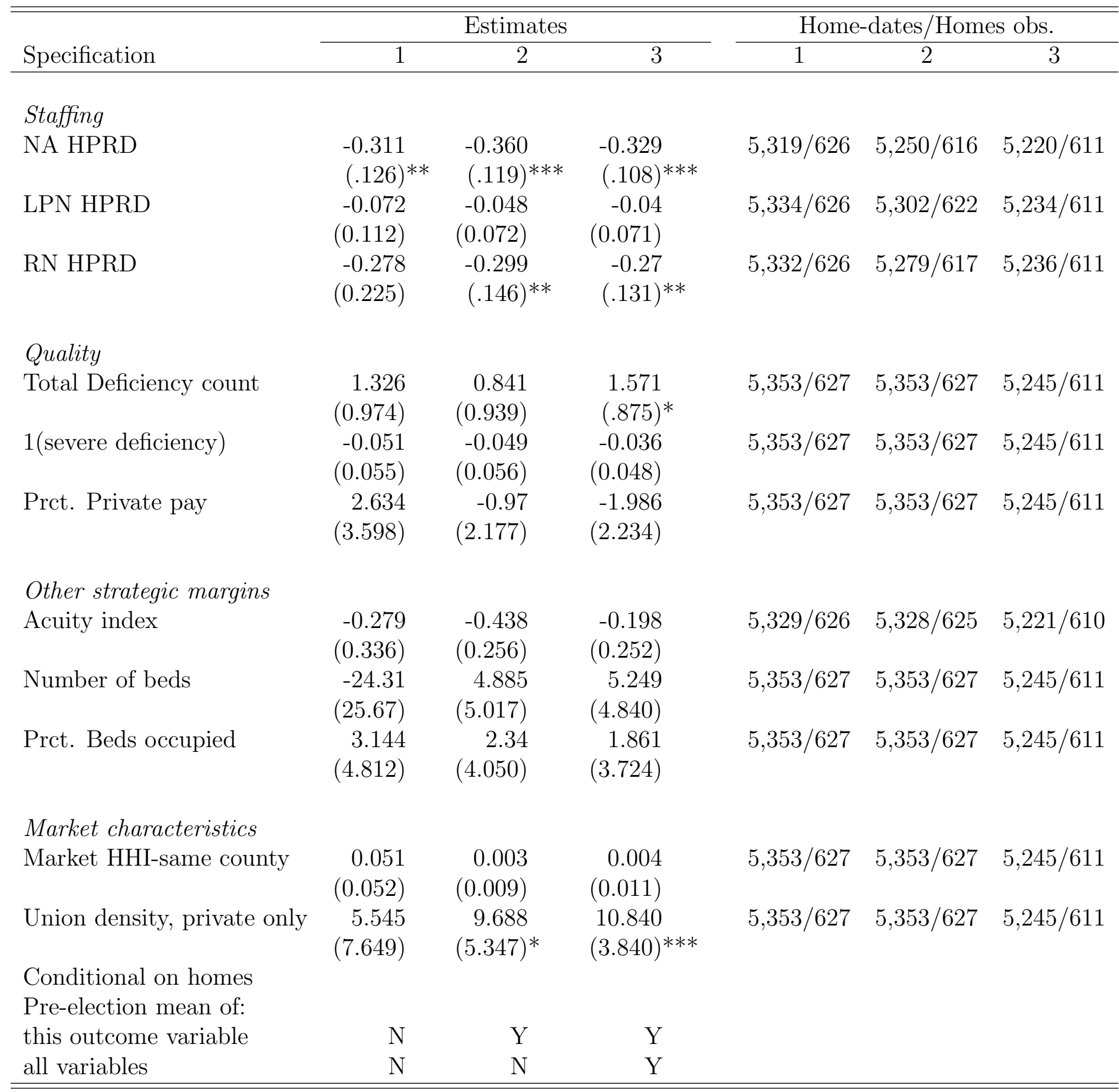

Coefficient (within-home cluster bootstrap SE). Significance: $\quad *: 10 \% \quad * *: 5 \% \quad * * *: 1 \%$.

Each cell presents discontinuity estimate from a separate local linear regression.

Number of home-dates observed varies due to missing outcomes or conditioning values.

Table A.13: Estimated effects on nursing homes characteristics using post-election panel and local linear estimator using a fixed bandwidth $(\mathrm{h}=0.12)$ 
Table A.14: Details of optimal bandwidth $(h)$, number of homes, number of home-dates, and outcome mean within optimal $h$ of threshold, and outcome mean in $h=0.5$ for each local linear regression in Tables 3, 4, 7, 8, 9, and 10

\begin{tabular}{|c|c|c|c|c|c|c|c|c|c|c|c|c|c|c|c|}
\hline \multirow[b]{3}{*}{ Variable } & \multicolumn{5}{|c|}{ Specification 1} & \multicolumn{5}{|c|}{ Specification 2} & \multicolumn{5}{|c|}{ Specification 3} \\
\hline & \multirow[b]{2}{*}{$\begin{array}{r}\text { Optm. } \\
h\end{array}$} & \multicolumn{3}{|c|}{ In optimal $h$} & \multirow{2}{*}{$\begin{array}{r}\text { Mean } \\
\text { in } \\
h=0.5\end{array}$} & \multirow[b]{2}{*}{$\begin{array}{r}\text { Optm. } \\
h\end{array}$} & \multicolumn{3}{|c|}{ In optimal $h$} & \multirow{2}{*}{$\begin{array}{r}\text { Mean } \\
\text { in } \\
h=0.5\end{array}$} & \multirow[b]{2}{*}{$\begin{array}{r}\text { Optm. } \\
h\end{array}$} & \multicolumn{3}{|c|}{ In optimal $h$} & \multirow{2}{*}{$\begin{array}{r}\text { Mean } \\
\text { in } \\
h=0.5\end{array}$} \\
\hline & & $\begin{array}{r}\text { Home- } \\
\text { dates }\end{array}$ & Homes & Mean & & & $\begin{array}{r}\text { Home- } \\
\text { dates }\end{array}$ & Homes & Mean & & & $\begin{array}{r}\text { Home- } \\
\text { dates }\end{array}$ & Homes & Mean & \\
\hline \multicolumn{16}{|l|}{ Table 3} \\
\hline NA HPRD & 0.09 & 2034 & 234 & 2.14 & 2.12 & 0.12 & 2009 & 230 & 2.14 & 2.12 & 0.09 & 1998 & 227 & 2.14 & 2.12 \\
\hline LPN HPRD & 0.10 & 2041 & 234 & 0.79 & 0.78 & 0.10 & 2022 & 232 & 0.79 & 0.77 & 0.10 & 2004 & 227 & 0.78 & 0.77 \\
\hline RN HPRD & 0.10 & 2038 & 234 & 0.52 & 0.5 & 0.08 & 2015 & 229 & 0.49 & 0.48 & 0.08 & 2005 & 227 & 0.49 & 0.48 \\
\hline Total deficiency count & 0.09 & 2046 & 235 & 6.41 & 6.87 & 0.09 & 2046 & 235 & 6.41 & 6.87 & 0.10 & 2008 & 227 & 6.45 & 6.9 \\
\hline 1(severe deficiency) & 0.20 & 3645 & 423 & 0.26 & 0.27 & 0.20 & 3645 & 423 & 0.26 & 0.27 & 0.22 & 3581 & 412 & 0.26 & 0.27 \\
\hline Pct. private pay & 0.10 & 2046 & 235 & 20.22 & 21.59 & 0.10 & 2046 & 235 & 20.22 & 21.59 & 0.10 & 2008 & 227 & 20.33 & 21.67 \\
\hline Total beds & 0.08 & 2046 & 235 & 131.51 & 124.74 & 0.08 & 2046 & 235 & 131.51 & 124.74 & 0.07 & 1125 & 126 & 133.34 & 124.93 \\
\hline Pct. beds occupied & 0.10 & 2046 & 235 & 84.77 & 85.28 & 0.10 & 2046 & 235 & 84.77 & 85.28 & 0.1 & 2008 & 227 & 85.3 & 85.53 \\
\hline Acuity index & 0.16 & 3034 & 350 & 10.23 & 10.22 & 0.16 & 3033 & 349 & 10.23 & 10.22 & 0.1 & 2002 & 226 & 10.25 & 10.20 \\
\hline HHI, in county & 0.08 & 2046 & 235 & 0.17 & 0.16 & 0.08 & 2046 & 235 & 0.17 & 0.16 & 0.08 & 2008 & 227 & 0.17 & 0.16 \\
\hline Union density & 0.12 & 2046 & 235 & 34.81 & 35.45 & 0.12 & 2046 & 235 & 34.81 & 35.45 & 0.12 & 2008 & 227 & 34.98 & 35.31 \\
\hline \multicolumn{16}{|l|}{ Table 4} \\
\hline Pct. urethral catheter & 0.28 & 4620 & 537 & 7.17 & 7.13 & 0.28 & 4620 & 537 & 7.17 & 7.13 & 0.09 & 2008 & 227 & 7.01 & 6.99 \\
\hline Pct. mobility restrained & 0.17 & 3045 & 351 & 9.24 & 9.5 & 0.17 & 3045 & 351 & 9.24 & 9.5 & 0.11 & 2008 & 227 & 9.15 & 9.53 \\
\hline Pct. spc. tube feed & 0.12 & 2046 & 235 & 6.9 & 6.86 & 0.12 & 2046 & 235 & 6.9 & 6.86 & 0.17 & 2981 & 340 & 6.84 & 6.67 \\
\hline Pct. psycho-active meds. & 0.08 & 2046 & 235 & 56.43 & 55.64 & 0.08 & 2046 & 235 & 56.43 & 55.64 & 0.08 & 2008 & 227 & 56.64 & 55.89 \\
\hline Pct. pressure sores & 0.08 & 2007 & 235 & 7.77 & 7.79 & 0.08 & 1369 & 179 & 8.07 & 8.22 & 0.08 & 1969 & 227 & 7.6 & 7.69 \\
\hline Pct. Bedfast & 0.12 & 2046 & 235 & 4.83 & 4.79 & 0.12 & 2046 & 235 & 4.83 & 4.79 & 0.13 & 2981 & 340 & 4.65 & 4.65 \\
\hline Pct. mobility chair & 0.19 & 3645 & 423 & 52.85 & 53.39 & 0.19 & 3645 & 423 & 52.85 & 53.39 & 0.2 & 3581 & 412 & 53.11 & 53.55 \\
\hline \multicolumn{16}{|l|}{ Table 7: Upper panel } \\
\hline NA HPRD & 0.09 & 1094 & 126 & 2.16 & 2.13 & 0.1 & 1079 & 124 & 2.16 & 2.12 & 0.09 & 1070 & 122 & 2.17 & 2.13 \\
\hline LPN HPRD & 0.15 & 1712 & 192 & 0.79 & 0.78 & 0.23 & 2215 & 250 & 0.8 & 0.78 & 0.15 & 1674 & 187 & 0.78 & 0.78 \\
\hline RN HPRD & 0.09 & 1094 & 126 & 0.56 & 0.5 & 0.08 & 1072 & 122 & 0.5 & 0.47 & 0.08 & 1072 & 122 & 0.5 & 0.47 \\
\hline Total deficiency count & 0.21 & 2008 & 227 & 6.78 & 7.06 & 0.21 & 2008 & 227 & 6.78 & 7.06 & 0.26 & 2190 & 246 & 6.92 & 7.13 \\
\hline 1(severe deficiency) & 0.44 & 2725 & 312 & 0.26 & 0.26 & 0.44 & 2725 & 312 & 0.26 & 0.26 & 0.32 & 2422 & 275 & 0.26 & 0.26 \\
\hline Pct. private pay & 0.1 & 1097 & 126 & 19.60 & 21.13 & 0.1 & 1097 & 126 & 19.60 & 21.13 & 0.11 & 1072 & 122 & 19.63 & 21.15 \\
\hline Total beds & 0.23 & 2228 & 251 & 119.12 & 119.05 & 0.23 & 2228 & 251 & 119.12 & 119.05 & 0.19 & 1970 & 222 & 118.3 & 118.96 \\
\hline Pct. beds occupied & 0.27 & 2228 & 251 & 83.82 & 84.3 & 0.27 & 2228 & 251 & 83.82 & 84.3 & 0.13 & 1676 & 187 & 84.95 & 84.64 \\
\hline
\end{tabular}




\begin{tabular}{|c|c|c|c|c|c|c|c|c|c|c|c|c|c|c|c|}
\hline \multirow[b]{3}{*}{ Variable } & \multicolumn{5}{|c|}{ Specification 1} & \multicolumn{5}{|c|}{ Specification 2} & \multicolumn{5}{|c|}{ Specification 3} \\
\hline & \multirow[b]{2}{*}{$\begin{array}{r}\text { Optm. } \\
h\end{array}$} & \multicolumn{3}{|c|}{ In optimal $h$} & \multirow{2}{*}{$\begin{array}{r}\text { Mean } \\
\text { in } \\
h=0.5\end{array}$} & \multirow[b]{2}{*}{$\begin{array}{r}\text { Optm. } \\
h\end{array}$} & \multicolumn{3}{|c|}{ In optimal $h$} & \multirow{2}{*}{$\begin{array}{r}\text { Mean } \\
\text { in } \\
h=0.5\end{array}$} & \multirow[b]{2}{*}{$\begin{array}{r}\text { Optm. } \\
h \\
\end{array}$} & \multicolumn{3}{|c|}{ In optimal $h$} & \multirow{2}{*}{$\begin{array}{r}\text { Mean } \\
\text { in } \\
h=0.5 \\
\end{array}$} \\
\hline & & $\begin{array}{r}\text { Home- } \\
\text { dates }\end{array}$ & Homes & Mean & & & $\begin{array}{r}\text { Home- } \\
\text { dates }\end{array}$ & Homes & Mean & & & $\begin{array}{r}\text { Home- } \\
\text { dates }\end{array}$ & Homes & Mean & \\
\hline Acuity index & 0.09 & 1094 & 126 & 10.11 & 10.16 & 0.09 & 1094 & 126 & 10.11 & 10.16 & 0.09 & 1069 & 122 & 10.14 & 10.18 \\
\hline $\mathrm{HHI}$, in county & 0.07 & 595 & 68 & 0.2 & 0.22 & 0.07 & 595 & 68 & 0.2 & 0.22 & 0.07 & 582 & 66 & 0.21 & 0.22 \\
\hline Union density & 0.08 & 1097 & 126 & 22.37 & 21.18 & 0.08 & 1097 & 126 & 22.37 & 21.18 & 0.08 & 1072 & 122 & 22.45 & 21.28 \\
\hline \multicolumn{16}{|l|}{ Table 7: Lower panel } \\
\hline NA HPRD & 0.24 & 1956 & 232 & 2.13 & 2.12 & 0.22 & 1602 & 191 & 2.11 & 2.11 & 0.21 & 1600 & 190 & 2.11 & 2.11 \\
\hline LPN HPRD & 0.17 & 1326 & 158 & 0.79 & 0.77 & 0.17 & 1317 & 157 & 0.79 & 0.76 & 0.17 & 1302 & 153 & 0.79 & 0.76 \\
\hline RN HPRD & 0.14 & 1325 & 158 & 0.51 & 0.51 & 0.13 & 1318 & 156 & 0.51 & 0.5 & 0.2 & 1607 & 190 & 0.52 & 0.49 \\
\hline Total deficiency count & 0.18 & 1637 & 196 & 6.38 & 6.67 & 0.18 & 1637 & 196 & 6.38 & 6.67 & 0.45 & 2510 & 299 & 6.66 & 6.66 \\
\hline 1(severe deficiency) & 0.17 & 1331 & 159 & 0.28 & 0.27 & 0.17 & 1331 & 159 & 0.28 & 0.27 & 0.16 & 1305 & 153 & 0.27 & 0.28 \\
\hline Pct. private pay & 0.09 & 949 & 109 & 20.94 & 22.07 & 0.09 & 949 & 109 & 20.94 & 22.07 & 0.1 & 936 & 105 & 21.13 & 22.22 \\
\hline Total beds & 0.07 & 556 & 64 & 136.34 & 130.67 & 0.07 & 556 & 64 & 136.34 & 130.67 & 0.07 & 543 & 60 & 137.33 & 131.25 \\
\hline Pct. beds occupied & 0.17 & 1331 & 159 & 86.02 & 86.31 & 0.17 & 1331 & 159 & 86.02 & 86.31 & 0.15 & 1305 & 153 & 86.16 & 86.47 \\
\hline Acuity index & 0.21 & 1634 & 195 & 10.32 & 10.28 & 0.21 & 1633 & 194 & 10.32 & 10.28 & 0.2 & 1608 & 189 & 10.32 & 10.23 \\
\hline HHI, in county & 0.05 & 556 & 64 & 0.10 & 0.10 & 0.05 & 556 & 64 & 0.10 & 0.10 & 0.05 & 543 & 60 & 0.11 & 0.10 \\
\hline Union density & 0.15 & 1331 & 159 & 49.69 & 50.33 & 0.15 & 1331 & 159 & 49.69 & 50.33 & 0.14 & 1305 & 153 & 49.87 & 50.14 \\
\hline \multicolumn{16}{|l|}{ Table 8: Upper panel } \\
\hline NA HPRD & 0.25 & 1884 & 230 & 2.18 & 2.17 & 0.21 & 1547 & 191 & 2.19 & 2.16 & 0.29 & 2084 & 256 & 2.19 & 2.16 \\
\hline LPN HPRD & 0.14 & 1352 & 165 & 0.81 & 0.79 & 0.14 & 1343 & 164 & 0.81 & 0.78 & 0.13 & 1333 & 161 & 0.81 & 0.78 \\
\hline RN HPRD & 0.15 & 1354 & 165 & 0.53 & 0.5 & 0.07 & 468 & 58 & 0.53 & 0.49 & 0.15 & 1335 & 161 & 0.52 & 0.49 \\
\hline Total deficiency count & 0.12 & 885 & 110 & 7.08 & 7.56 & 0.12 & 885 & 110 & 7.08 & 7.56 & 0.19 & 1549 & 190 & 7.23 & 7.58 \\
\hline 1(severe deficiency) & 0.1 & 885 & 110 & 0.3 & 0.29 & 0.1 & 885 & 110 & 0.3 & 0.29 & 0.11 & 871 & 106 & 0.29 & 0.29 \\
\hline Pct. private pay & 0.09 & 885 & 110 & 19.66 & 22.38 & 0.09 & 885 & 110 & 19.66 & 22.38 & 0.09 & 871 & 106 & 19.71 & 22.5 \\
\hline Total beds & 0.09 & 885 & 110 & 136.14 & 130.30 & 0.09 & 885 & 110 & 136.14 & 130.30 & 0.08 & 871 & 106 & 136.83 & 130.66 \\
\hline Pct. beds occupied & 0.09 & 885 & 110 & 85.21 & 84.98 & 0.09 & 885 & 110 & 85.21 & 84.98 & 0.1 & 871 & 106 & 85.16 & 85.04 \\
\hline Acuity index & 0.17 & 1353 & 166 & 10.35 & 10.34 & 0.17 & 1352 & 165 & 10.35 & 10.34 & 0.15 & 1333 & 161 & 10.36 & 10.31 \\
\hline HHI, in county & 0.07 & 473 & 60 & 0.03 & 0.03 & 0.07 & 473 & 60 & 0.03 & 0.03 & 0.07 & 459 & 56 & 0.03 & 0.03 \\
\hline Union density & 0.14 & 1357 & 166 & 33 & 35.46 & 0.14 & 1357 & 166 & 33 & 35.46 & 0.13 & 1337 & 161 & 33 & 35.24 \\
\hline \multicolumn{16}{|l|}{ Table 8: Lower panel } \\
\hline NA HPRD & 0.08 & 1153 & 125 & 2.11 & 2.08 & 0.08 & 1138 & 123 & 2.11 & 2.08 & 0.08 & 1130 & 121 & 2.11 & 2.08 \\
\hline LPN HPRD & 0.24 & 2301 & 253 & 0.78 & 0.77 & 0.19 & 2062 & 227 & 0.78 & 0.76 & 0.11 & 1136 & 121 & 0.79 & 0.76 \\
\hline RN HPRD & 0.08 & 1156 & 125 & 0.56 & 0.51 & 0.09 & 1136 & 121 & 0.51 & 0.47 & 0.09 & 1136 & 121 & 0.51 & 0.48 \\
\hline
\end{tabular}




\begin{tabular}{|c|c|c|c|c|c|c|c|c|c|c|c|c|c|c|c|}
\hline \multirow[b]{3}{*}{ Variable } & \multicolumn{5}{|c|}{ Specification 1} & \multicolumn{5}{|c|}{ Specification 2} & \multicolumn{5}{|c|}{ Specification 3} \\
\hline & \multirow[b]{2}{*}{$\begin{array}{r}\text { Optm. } \\
h\end{array}$} & \multicolumn{3}{|c|}{ In optimal $h$} & \multirow{2}{*}{$\begin{array}{r}\text { Mean } \\
\text { in } \\
h=0.5\end{array}$} & \multirow[b]{2}{*}{$\begin{array}{r}\text { Optm. } \\
h\end{array}$} & \multicolumn{3}{|c|}{ In optimal $h$} & \multirow{2}{*}{$\begin{array}{r}\text { Mean } \\
\text { in } \\
h=0.5\end{array}$} & \multirow[b]{2}{*}{$\begin{array}{r}\text { Optm. } \\
h\end{array}$} & \multicolumn{3}{|c|}{ In optimal $h$} & \multirow{2}{*}{$\begin{array}{r}\text { Mean } \\
\text { in } \\
h=0.5\end{array}$} \\
\hline & & $\begin{array}{r}\text { Home- } \\
\text { dates }\end{array}$ & Homes & Mean & & & $\begin{array}{r}\text { Home- } \\
\text { dates }\end{array}$ & Homes & Mean & & & $\begin{array}{r}\text { Home- } \\
\text { dates }\end{array}$ & Homes & Mean & \\
\hline Total deficiency count & 0.09 & 1161 & 125 & 5.89 & 6.25 & 0.09 & 1161 & 125 & 5.89 & 6.25 & 0.09 & 1137 & 121 & 5.97 & 6.29 \\
\hline 1 (severe deficiency) & 0.09 & 1161 & 125 & 0.22 & 0.24 & 0.09 & 1161 & 125 & 0.22 & 0.24 & 0.09 & 1137 & 121 & 0.22 & 0.24 \\
\hline Pct. private pay & 0.07 & 678 & 72 & 20.46 & 20.88 & 0.07 & 678 & 72 & 20.46 & 20.88 & 0.07 & 666 & 70 & 20.52 & 20.92 \\
\hline Total beds & 0.09 & 1161 & 125 & 127.98 & 119.76 & 0.09 & 1161 & 125 & 127.98 & 119.76 & 0.08 & 1137 & 121 & 127.17 & 119.77 \\
\hline Pct. beds occupied & 0.19 & 2076 & 228 & 84.77 & 85.56 & 0.19 & 2076 & 228 & 84.77 & 85.56 & 0.14 & 1644 & 179 & 85.98 & 85.97 \\
\hline Acuity index & 0.08 & 1157 & 124 & 10.23 & 10.11 & 0.08 & 1157 & 124 & 10.23 & 10.11 & 0.08 & 1133 & 120 & 10.26 & 10.11 \\
\hline HHI, in county & 0.07 & 678 & 72 & 0.24 & 0.27 & 0.07 & 678 & 72 & 0.24 & 0.27 & 0.07 & 666 & 70 & 0.25 & 0.27 \\
\hline Union density & 0.1 & 1161 & 125 & 37.16 & 35.44 & 0.1 & 1161 & 125 & 37.16 & 35.44 & 0.09 & 1137 & 121 & 37.46 & 35.38 \\
\hline \multicolumn{16}{|l|}{ Table 9: Upper panel } \\
\hline NA HPRD & 0.1 & 1356 & 174 & 2.16 & 2.13 & 0.1 & 1337 & 172 & 2.17 & 2.13 & 0.1 & 1332 & 170 & 2.16 & 2.13 \\
\hline LPN HPRD & 0.11 & 1362 & 174 & 0.82 & 0.79 & 0.11 & 1343 & 172 & 0.82 & 0.79 & 0.11 & 1338 & 170 & 0.81 & 0.79 \\
\hline RN HPRD & 0.23 & 2798 & 355 & 0.55 & 0.52 & 0.26 & 2779 & 351 & 0.53 & 0.51 & 0.25 & 2760 & 349 & 0.54 & 0.51 \\
\hline Total deficiency count & 0.19 & 2444 & 311 & 6.74 & 7.09 & 0.19 & 2444 & 311 & 6.74 & 7.09 & 0.37 & 3294 & 420 & 7.06 & 7.1 \\
\hline 1 (severe deficiency) & 0.15 & 2048 & 262 & 0.24 & 0.26 & 0.15 & 2048 & 262 & 0.24 & 0.26 & 0.14 & 2006 & 255 & 0.25 & 0.26 \\
\hline Pct. private pay & 0.1 & 1364 & 175 & 21.76 & 23.09 & 0.1 & 1364 & 175 & 21.76 & 23.09 & 0.1 & 1339 & 170 & 21.85 & 23.12 \\
\hline Total beds & 0.07 & 803 & 102 & 129.26 & 123.32 & 0.07 & 803 & 102 & 129.26 & 123.32 & 0.1 & 1339 & 170 & 127.38 & 123.11 \\
\hline Pct. beds occupied & 0.1 & 1364 & 175 & 82.96 & 84.04 & 0.1 & 1364 & 175 & 82.96 & 84.04 & 0.09 & 1339 & 170 & 83.58 & 84.24 \\
\hline Acuity index & 0.1 & 1361 & 175 & 10.15 & 10.15 & 0.1 & 1361 & 175 & 10.15 & 10.15 & 0.1 & 1336 & 170 & 10.17 & 10.13 \\
\hline HHI, in county & 0.1 & 1364 & 175 & 0.12 & 0.12 & 0.1 & 1364 & 175 & 0.12 & 0.12 & 0.1 & 1339 & 170 & 0.12 & 0.12 \\
\hline Union density & 0.14 & 2048 & 262 & 32.45 & 33.80 & 0.14 & 2048 & 262 & 32.45 & 33.80 & 0.15 & 2006 & 255 & 32.63 & 33.77 \\
\hline \multicolumn{16}{|l|}{ Table 9: Lower panel } \\
\hline NA HPRD & 0.09 & 678 & 102 & 2.09 & 2.1 & 0.14 & 978 & 148 & 2.05 & 2.1 & 0.09 & 666 & 99 & 2.09 & 2.09 \\
\hline LPN HPRD & 0.23 & 1389 & 213 & 0.75 & 0.75 & 0.22 & 1197 & 183 & 0.75 & 0.74 & 0.11 & 666 & 99 & 0.73 & 0.73 \\
\hline RN HPRD & 0.09 & 677 & 102 & 0.48 & 0.46 & 0.08 & 667 & 100 & 0.42 & 0.43 & 0.08 & 666 & 99 & 0.42 & 0.42 \\
\hline Total deficiency count & 0.07 & 348 & 49 & 6.11 & 6.41 & 0.07 & 348 & 49 & 6.11 & 6.41 & 0.07 & 347 & 48 & 6.12 & 6.48 \\
\hline 1(severe deficiency) & 0.07 & 348 & 49 & 0.24 & 0.28 & 0.07 & 348 & 49 & 0.24 & 0.07 & 0.08 & 669 & 99 & 0.28 & 0.28 \\
\hline Pct. private pay & 0.07 & 348 & 49 & 16.51 & 18.5 & 0.07 & 348 & 49 & 16.51 & 18.5 & 0.08 & 669 & 99 & 17.28 & 18.65 \\
\hline Total beds & 0.17 & 997 & 152 & 130.57 & 127.66 & 0.17 & 997 & 152 & 130.57 & 127.66 & 0.1 & 669 & 99 & 139.34 & 128.74 \\
\hline Pct. beds occupied & 0.13 & 997 & 152 & 88.9 & 87.84 & 0.13 & 997 & 152 & 88.9 & 87.84 & 0.09 & 669 & 99 & 88.73 & 88.22 \\
\hline Acuity index & 0.13 & 991 & 151 & 10.44 & 10.37 & 0.13 & 990 & 150 & 10.44 & 10.37 & 0.13 & 969 & 146 & 10.45 & 10.35 \\
\hline HHI, in county & 0.08 & 682 & 102 & 0.27 & 0.23 & 0.08 & 682 & 102 & 0.27 & 0.23 & 0.08 & 669 & 99 & 0.27 & 0.23 \\
\hline Union density & 0.08 & 682 & 102 & 39.03 & 38.84 & 0.08 & 682 & 102 & 39.03 & 38.84 & 0.08 & 669 & 99 & 39.35 & 38.52 \\
\hline
\end{tabular}




\begin{tabular}{|c|c|c|c|c|c|c|c|c|c|c|c|c|c|c|c|}
\hline \multirow[b]{3}{*}{ Variable } & \multicolumn{5}{|c|}{ Specification 1} & \multicolumn{5}{|c|}{ Specification 2} & \multicolumn{5}{|c|}{ Specification 3} \\
\hline & \multirow[b]{2}{*}{$\begin{array}{r}\text { Optm. } \\
h\end{array}$} & \multicolumn{3}{|c|}{ In optimal $h$} & \multirow{2}{*}{$\begin{array}{r}\text { Mean } \\
\text { in } \\
h=0.5\end{array}$} & \multirow[b]{2}{*}{$\begin{array}{r}\text { Optm. } \\
h\end{array}$} & \multicolumn{3}{|c|}{ In optimal $h$} & \multirow{2}{*}{$\begin{array}{r}\text { Mean } \\
\text { in } \\
h=0.5 \\
\end{array}$} & \multirow[b]{2}{*}{$\begin{array}{r}\text { Optm. } \\
h\end{array}$} & \multicolumn{3}{|c|}{ In optimal $h$} & \multirow{2}{*}{$\begin{array}{r}\text { Mean } \\
\text { in } \\
h=0.5\end{array}$} \\
\hline & & $\begin{array}{r}\text { Home- } \\
\text { dates }\end{array}$ & Homes & Mean & & & $\begin{array}{r}\text { Home- } \\
\text { dates }\end{array}$ & Homes & Mean & & & $\begin{array}{r}\text { Home- } \\
\text { dates }\end{array}$ & Homes & Mean & \\
\hline \multicolumn{16}{|l|}{ Table 10: Upper panel } \\
\hline NA HPRD & 0.13 & 1480 & 349 & 2.12 & 2.1 & 0.14 & 1455 & 342 & 2.12 & 2.1 & 0.13 & 1445 & 339 & 2.12 & 2.1 \\
\hline LPN HPRD & 0.19 & 1791 & 422 & 0.79 & 0.76 & 0.25 & 2056 & 481 & 0.77 & 0.76 & 0.11 & 986 & 227 & 0.78 & 0.75 \\
\hline RN HPRD & 0.09 & 1007 & 234 & 0.62 & 0.57 & 0.12 & 992 & 229 & 0.58 & 0.55 & 0.1 & 987 & 227 & 0.58 & 0.55 \\
\hline Total deficiency count & 0.1 & 1014 & 235 & 6.04 & 6.85 & 0.1 & 1014 & 235 & 6.04 & 6.85 & 0.09 & 990 & 227 & 6.1 & 6.89 \\
\hline 1(severe deficiency) & 0.19 & 1798 & 423 & 0.29 & 0.3 & 0.19 & 1798 & 423 & 0.29 & 0.3 & 0.19 & 1760 & 412 & 0.29 & 0.3 \\
\hline Pct. private pay & 0.07 & 568 & 132 & 21.19 & 22.14 & 0.07 & 568 & 132 & 21.19 & 22.14 & 0.07 & 553 & 126 & 21.2 & 22.16 \\
\hline Total beds & 0.1 & 1014 & 235 & 132.82 & 126.53 & 0.1 & 1014 & 235 & 132.82 & 126.53 & 0.09 & 990 & 227 & 133.09 & 126.81 \\
\hline Pct. beds occupied & 0.13 & 1493 & 351 & 84.35 & 84.97 & 0.13 & 1493 & 351 & 84.35 & 84.97 & 0.13 & 1455 & 340 & 84.74 & 85.23 \\
\hline Acuity index & 0.17 & 1482 & 350 & 10.24 & 10.21 & 0.17 & 1481 & 349 & 10.24 & 10.21 & 0.16 & 1444 & 339 & 10.25 & 10.20 \\
\hline HHI, in county & 0.12 & 1014 & 235 & 0.16 & 0.15 & 0.12 & 1014 & 235 & 0.16 & 0.15 & 0.15 & 1455 & 340 & 0.15 & 0.15 \\
\hline Union density & 0.18 & 1798 & 423 & 32.59 & 34.68 & 0.18 & 1798 & 423 & 32.59 & 34.68 & 0.19 & 1760 & 412 & 32.71 & 34.51 \\
\hline \multicolumn{16}{|l|}{ Table 10: Lower panel } \\
\hline NA HPRD & 0.12 & 1032 & 206 & 2.16 & 2.14 & 0.14 & 1526 & 302 & 2.14 & 2.13 & 0.14 & 1525 & 301 & 2.14 & 2.13 \\
\hline LPN HPRD & 0.12 & 1032 & 206 & 0.79 & 0.8 & 0.12 & 1021 & 204 & 0.79 & 0.78 & 0.12 & 1018 & 202 & 0.79 & 0.79 \\
\hline RN HPRD & 0.22 & 1846 & 369 & 0.46 & 0.44 & 0.14 & 1541 & 304 & 0.42 & 0.42 & 0.09 & 1018 & 202 & 0.4 & 0.42 \\
\hline Total deficiency count & 0.13 & 1552 & 308 & 6.82 & 6.89 & 0.13 & 1552 & 308 & 6.82 & 6.89 & 0.12 & 1018 & 202 & 6.78 & 6.9 \\
\hline 1(severe deficiency) & 0.26 & 2127 & 424 & 0.23 & 0.23 & 0.26 & 2127 & 424 & 0.23 & 0.23 & 0.17 & 1526 & 301 & 0.23 & 0.23 \\
\hline Pct. private pay & 0.11 & 1032 & 206 & 19.49 & 21.04 & 0.11 & 1032 & 206 & 19.49 & 21.04 & 0.11 & 1018 & 202 & 19.55 & 21.18 \\
\hline Total beds & 0.08 & 1032 & 206 & 130.23 & 122.95 & 0.08 & 1032 & 206 & 130.23 & 122.95 & 0.08 & 1018 & 202 & 129.68 & 123.07 \\
\hline Pct. beds occupied & 0.17 & 1552 & 308 & 85.83 & 85.59 & 0.17 & 1552 & 308 & 85.83 & 85.59 & 0.13 & 1526 & 301 & 86.19 & 85.83 \\
\hline Acuity index & 0.17 & 1552 & 308 & 10.22 & 10.23 & 0.17 & 1552 & 308 & 10.22 & 10.23 & 0.17 & 1526 & 301 & 10.23 & 10.20 \\
\hline HHI, in county & 0.08 & 1032 & 206 & 0.17 & 0.17 & 0.08 & 1032 & 206 & 0.17 & 0.17 & 0.08 & 1018 & 202 & 0.18 & 0.17 \\
\hline Union density & 0.12 & 1032 & 206 & 36.71 & 36.21 & 0.12 & 1032 & 206 & 36.71 & 36.21 & 0.12 & 1018 & 202 & 36.85 & 36.11 \\
\hline
\end{tabular}




\begin{tabular}{lrrrr}
\hline \hline Sample: & \multicolumn{2}{c}{ All observations } & \multicolumn{2}{c}{ Post-election only } \\
Variable & Mean & SD & Mean & SD \\
\hline & & & & \\
Census variables & & & & \\
Payroll (millions of Y2000\$) & 5.4 & 14.9 & 6.1 & 17.0 \\
Employment & 216 & 414.6 & 220.9 & 427.1 \\
Avg annual earnings (Y2000\$) & 20,871 & 19,965 & 24,212 & 28,391 \\
& & & & \\
OSCAR variables & & & & \\
NA HPRD & 2.12 & 0.74 & 2.12 & 0.70 \\
RN HPRD & 0.60 & 0.79 & 0.50 & 0.74 \\
LPN HPRD & 0.71 & 0.48 & 0.77 & 0.46 \\
Total deficiency count & 6.76 & 6.36 & 6.76 & 5.79 \\
1(severe deficiency) & 0.23 & & 0.26 & \\
Prct. private pay & 23.1 & 17.5 & 21.9 & 16.1 \\
Acuity index & 10.2 & 1.54 & 10.2 & 1.5 \\
Number of beds & 123.2 & 68.8 & 122 & 63.3 \\
Prct. beds occupied & 85.6 & 18.6 & 85.9 & 16.7 \\
Market HHI same county & 0.15 & 0.19 & 0.16 & 0.19 \\
Union density, private only & 30.7 & 26.1 & 34.7 & 26.8 \\
\hline \hline
\end{tabular}

Table A.15: Means of Census and OSCAR variables in Census subsample 


\begin{tabular}{|c|c|c|c|c|c|c|}
\hline \multirow[b]{2}{*}{ Specification } & \multicolumn{3}{|c|}{ Estimates } & \multicolumn{3}{|c|}{ Home-dates obs. } \\
\hline & 1 & 2 & 3 & 1 & 2 & 3 \\
\hline \multicolumn{7}{|l|}{ Staffing } \\
\hline NA HPRD & $\begin{array}{r}-0.191 \\
(.165)\end{array}$ & $\begin{array}{r}-0.169 \\
(.137)\end{array}$ & $\begin{array}{r}-0.154 \\
(.104)\end{array}$ & 3627 & 3575 & 3559 \\
\hline LPN HPRD & $\begin{array}{l}0.009 \\
(0.124)\end{array}$ & $\begin{array}{r}-0.026 \\
(0.068)\end{array}$ & $\begin{array}{r}-0.020 \\
(0.070)\end{array}$ & 3637 & 3606 & 3569 \\
\hline RN HPRD & $\begin{array}{r}-0.289 \\
(0.265)\end{array}$ & $\begin{array}{r}-0.103 \\
(0.128)\end{array}$ & $\begin{array}{r}-0.173 \\
(0.114)\end{array}$ & 3634 & 3610 & 3568 \\
\hline \multicolumn{7}{|l|}{ Quality } \\
\hline Total deficiency count & $\begin{array}{l}0.765 \\
(1.040)\end{array}$ & $\begin{array}{l}0.904 \\
(0.941)\end{array}$ & $\begin{array}{l}1.330 \\
(0.985)\end{array}$ & 3646 & 3646 & 3576 \\
\hline 1(severe deficiency) & $\begin{array}{r}-0.064 \\
(0.051)\end{array}$ & $\begin{array}{r}-0.065 \\
(0.051)\end{array}$ & $\begin{array}{r}-0.031 \\
(0.036)\end{array}$ & 3646 & 3646 & 3576 \\
\hline Prct. private pay & $\begin{array}{l}7.898 \\
(4.860)\end{array}$ & $\begin{array}{l}3.383 \\
(3.140)\end{array}$ & $\begin{array}{l}1.230 \\
(2.550)\end{array}$ & 3646 & 3646 & 3576 \\
\hline \multicolumn{7}{|l|}{ Other strategic margins } \\
\hline Acuity index & $\begin{array}{l}0.005 \\
(0.438)\end{array}$ & $\begin{array}{r}-0.162 \\
(0.277)\end{array}$ & $\begin{array}{l}0.017 \\
(0.211)\end{array}$ & 3630 & 3629 & 3560 \\
\hline Number of beds & $\begin{array}{r}-12.170 \\
(24.020)\end{array}$ & $\begin{array}{l}1.696 \\
(4.850)\end{array}$ & $\begin{array}{l}4.800 \\
(3.270)\end{array}$ & 3646 & 3646 & 3576 \\
\hline Prct. beds occupied & $\begin{array}{l}1.460 \\
(5.750)\end{array}$ & $\begin{array}{l}0.682 \\
(3.360)\end{array}$ & $\begin{array}{l}2.230 \\
(2.950)\end{array}$ & 3646 & 3646 & 3576 \\
\hline \multicolumn{7}{|l|}{ Market characteristics } \\
\hline Market HHI & $\begin{array}{r}-0.015 \\
(0.056)\end{array}$ & $\begin{array}{l}0.000 \\
(0.008)\end{array}$ & $\begin{array}{l}0.000 \\
(0.003)\end{array}$ & 3646 & 3646 & 3576 \\
\hline Union density & $\begin{array}{l}6.190 \\
(7.580)\end{array}$ & $\begin{array}{l}6.190 \\
(5.650)\end{array}$ & $\begin{array}{l}9.630 \\
(3.440)\end{array}$ & 3646 & 3646 & 3576 \\
\hline
\end{tabular}

Specification conditional on home's pre-election mean of:

$\begin{array}{llll}\text { This outcome variable } & \mathrm{N} & \mathrm{Y} & \mathrm{Y}\end{array}$

\begin{tabular}{llll} 
All other outcome variables & $\mathrm{N}$ & $\mathrm{N}$ & $\mathrm{Y}$ \\
\hline \hline
\end{tabular}

Coefficient (within-home cluster bootstrap SE). Significance: $\quad *: 10 \% \quad * *: 5 \% \quad * * *: 1 \%$.

Each cell presents discontinuity estimate from a separate local linear regression.

Table A.16: Estimated effects on nursing homes characteristics using post-election OSCAR panel and local linear estimator in the Census subsample 


\section{A.2 Figures}

Outcome: Acuity index

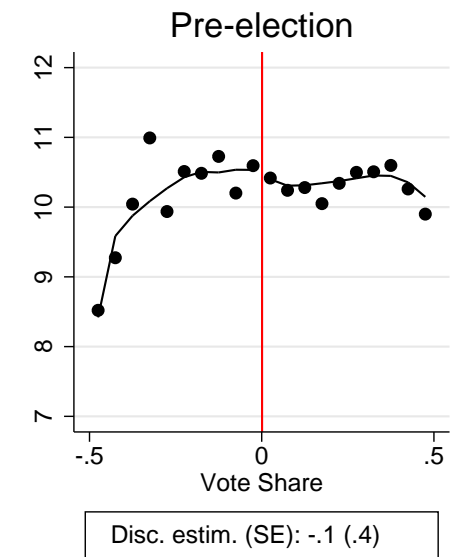

Note: both use the IK-optimal bandwidth for post-election sample: 0.161 .

(a)

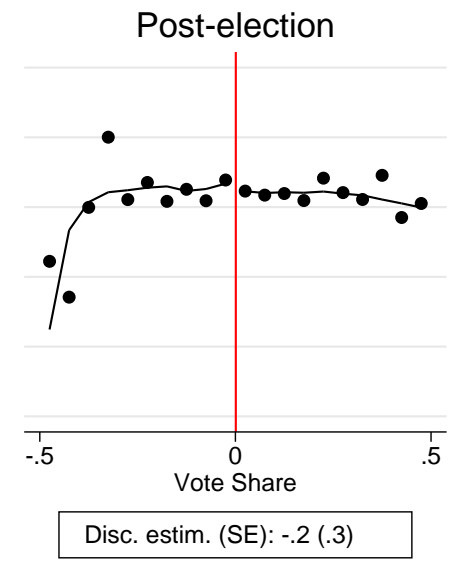

Outcome: Total beds
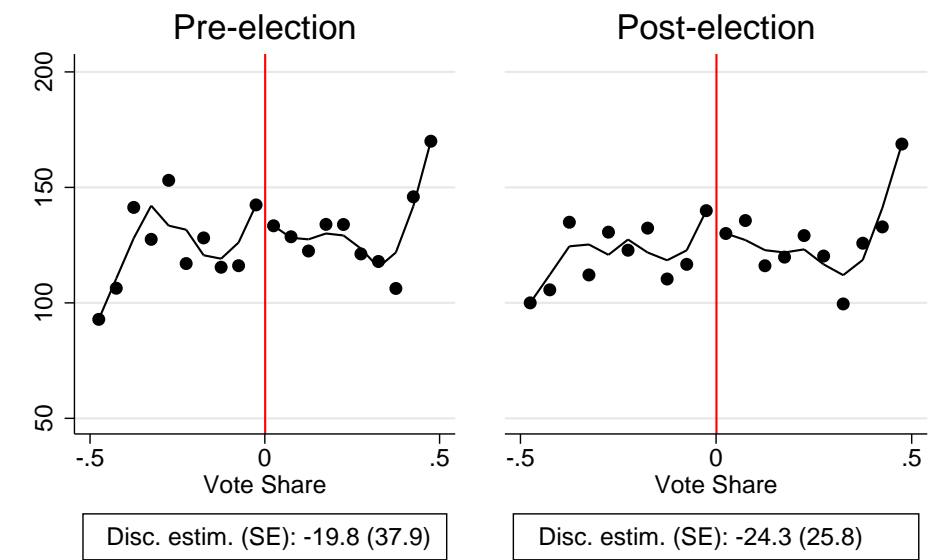

Note: both use the IK-optimal bandwidth for post-election sample: 0.08 .

(b)

Outcome: Pct. beds occupied
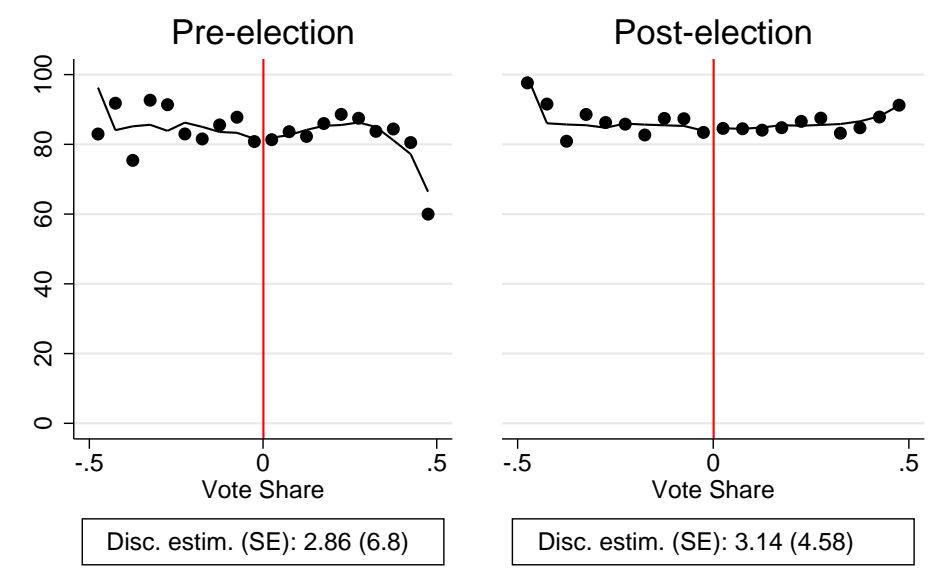

Note: both use the IK-optimal bandwidth for post-election sample: 0.104

(c)

Figure A.1: Other strategic margins: expected acuity index, total number of beds, and percentage of beds occupied by vote share bin in the pre- and post-election periods are plotted. Estimated expectations from local-linear regression on either side of the threshold using the IK-optimal bandwidth as in specification 1 of Table 3 is graphed. 


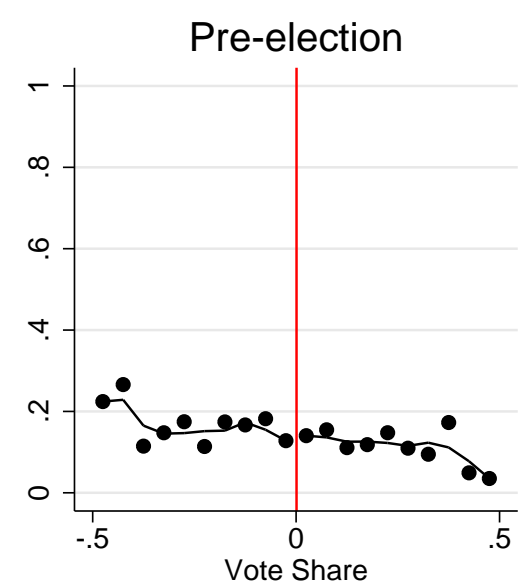

Disc. estim. (SE): .032 (.052)
Post-election

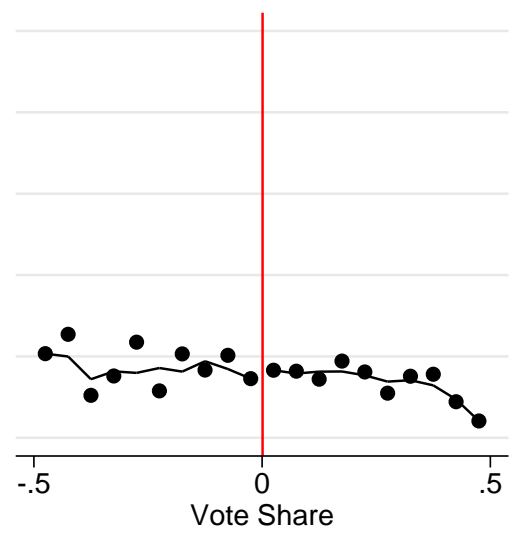

Disc. estim. (SE): .051 (.051)

Note: both use the IK-optimal bandwidth for post-election sample: 0.081 .

Figure A.2: Expected market concentration (HHI in county) by vote share bin in the preand post-election periods are plotted. Estimated expectations from local-linear regression on either side of the threshold using the IK-optimal bandwidth as in specification 1 of Table 3 is graphed.

\section{Outcome: Union density}
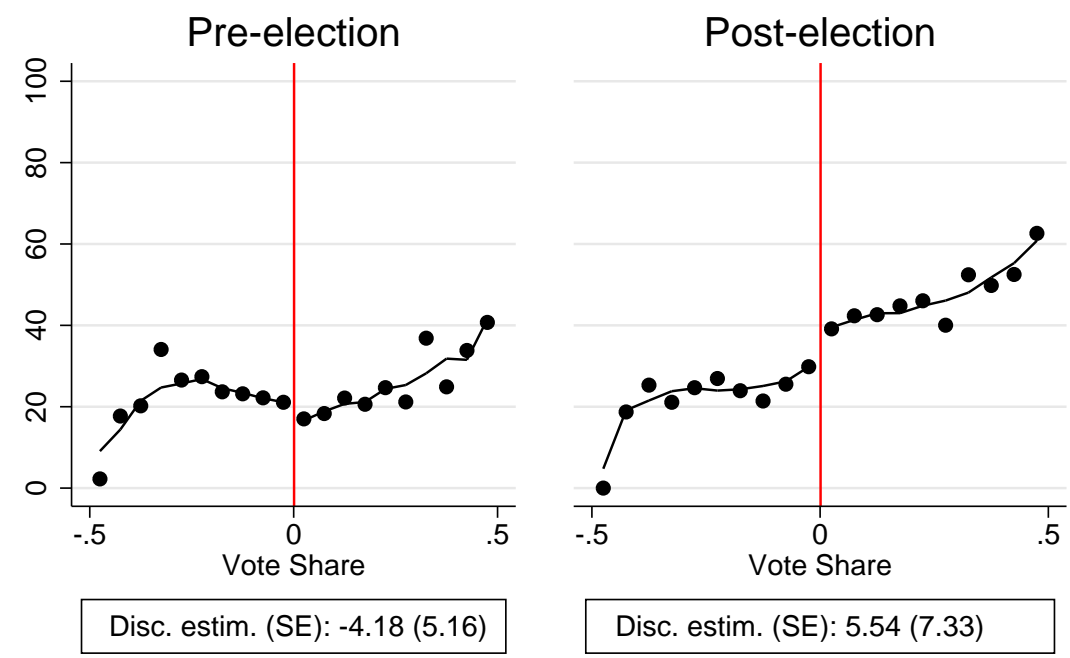

Note: both use the IK-optimal bandwidth for post-election sample: 0.12

Figure A.3: Expected union density (private-sector only) by vote share bin in the pre- and post-election periods are plotted. Estimated expectations from local-linear regression on either side of the threshold using the IK-optimal bandwidth as in specification 1 of Table 3 is graphed. 